\title{
CLIVAGEM DE PROTEÍNAS DO COMPLEXO DE ATAQUE À MEMBRANA DO SISTEMA COMPLEMENTO HUMANO POR PROTEASES DE LEPTOSPIRAS PATOGÊNICAS
}

Dissertação apresentada ao Programa de Pós-Graduação em Imunologia do Instituto de Ciências Biomédicas da Universidade de São Paulo, para obtenção do Título de Mestre em Ciências. 


\section{CLIVAGEM DE PROTEÍNAS DO COMPLEXO DE ATAQUE À MEMBRANA DO SISTEMA COMPLEMENTO HUMANO POR PROTEASES DE LEPTOSPIRAS PATOGÊNICAS}

Dissertação apresentada ao Programa de Pós-Graduação em Imunologia do Instituto de Ciências Biomédicas da Universidade de São Paulo, para obtenção do Título de Mestre em Ciências.

Área de concentração: Imunologia

Orientadora: Prof ${ }^{\mathrm{a}} \mathrm{Dr}^{\mathrm{a}}$ Lourdes Isaac

Versão Original 


\section{CATALOGAÇÃO NA PUBLICAÇÃO (CIP) \\ Serviço de Biblioteca e informaçăo Biomédica \\ do Instituto de Ciências Biomédicas da Universidade de São Paulo}

Ficha Catalográfica elaborada pelo(a) autor(a)

Amamura, Thais Akemi

Clivagem de Proteínas do Complexo de Ataque à

Membrana do Sistema Complemento Humano por

Proteases de Leptospiras Patogênicas/ Thais Akemi Amamura; orientador Lourdes Isaac . -- São Paulo,

2016.

$100 \mathrm{p}$.

Dissertação (Mestrado) ) -- Universidade de São Paulo, Instituto de Ciências Biomédicas.

1. Leptospirose. 2. Imunoproteínas. 3. Infecções

bacterianas. 4. Imunoquimica. 5. Imunologia. I.

Isaac, Lourdes, orientador. II. Título. 
Candidato(a):

Titulo da Dissertação/Tese:

Orientador:

A Comissão Julgadora dos trabalhos de Defesa da Dissertação de Mestrado/Tese de Doutorado, em sessão publica realizada a .............................. considerou o(a) candidato(a):

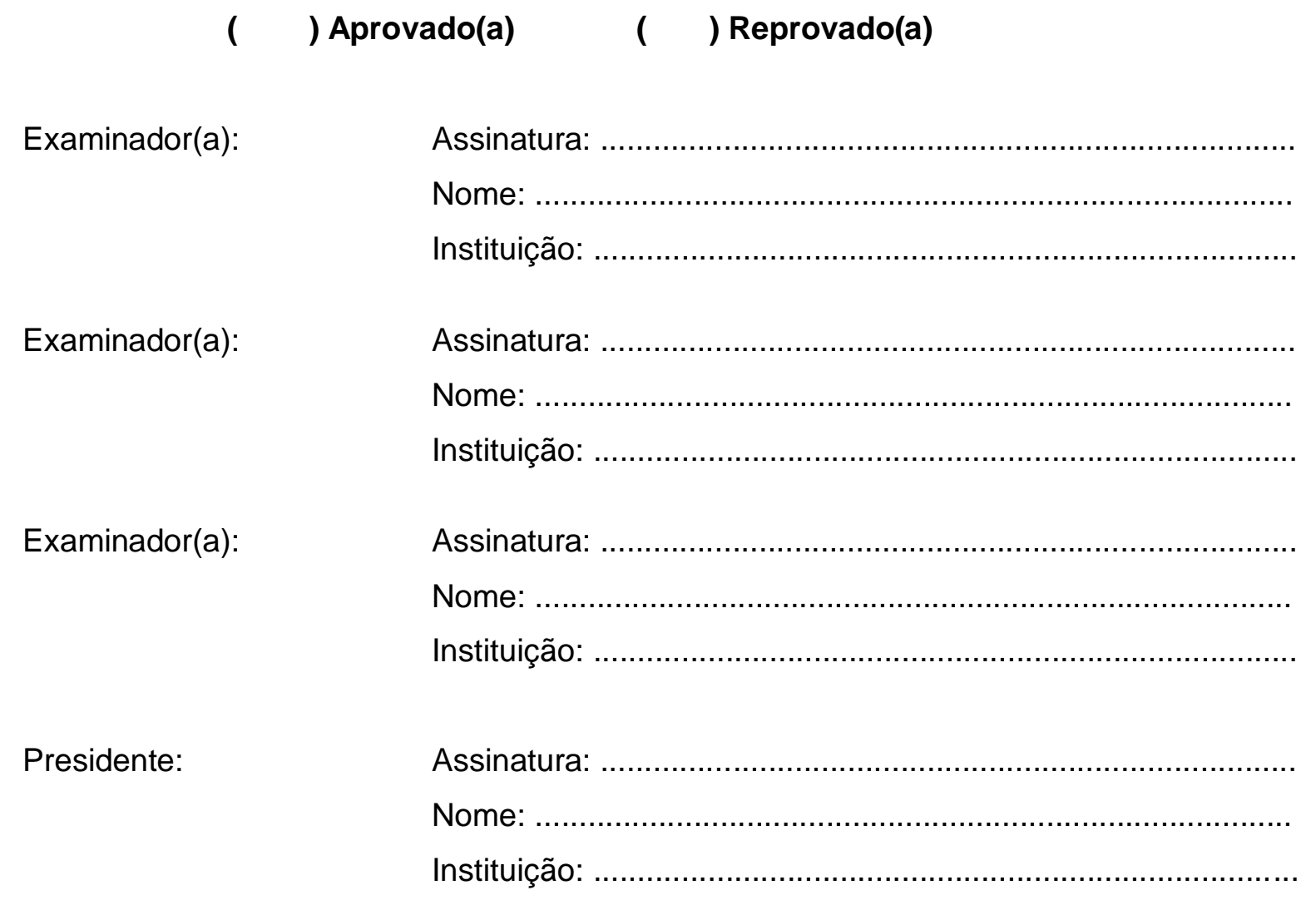


Cidade Universitária "Armando de Salles Oliveira"

Av. Prof. Lineu Prestes, 2415 - cep. 05508-000 São Paulo, SP - Brasil

Av. Prof. Lineu Prestes, 2415 - cep. 05508-000 São Paulo,
Telefone :(55) (11) 3091.7733 telefax : (55) (11) 3091-8405

e-mail: cep@ icb.usp.br

São Paulo, 15 de dezembro de 2014.

\section{PARECER 1206/CEPSH}

A Comissão de Ética em Pesquisas em Seres Humanos do ICB, nesta data, AProvou o projeto intitulado: Clivagem de Proteínas do Complexo de Ataque à Membrana por Proteases de Leptospiras Patogênicas " da Pesquisadora Profa. Dra LOURDES ISAAC e aluna THAIS AKEMI AMAMURA.

Cabe aos pesquisadores elaborar e apresentar a este Comitê, relatórios anuais (parciais e final), de acordo com a Resolução n 466/12, item II, II.19 e II.20, do Conselho Nacional de Saúde, conforme modelo constante no site: icb.usp.br.

Aos pesquisadores cabe também finalizar o processo junto à Plataforma Brasil quando do encerramento deste.

O primeiro relatório deverá ser encaminhado à Secretaria deste CEP em 15.12.2015.

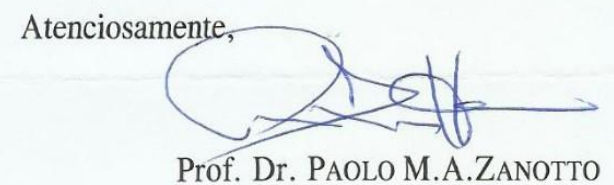

Coordenador da Comissão de Ética em

Pesquisas com Seres Humanos - ICB/USP

Comissão de Ética em Pesquisa com Seres Humanos do Instituto de Ciências Biomédicas / USP Aprovada pela Comissão Nacional de Ética em Pesquisa - CONEP, em 10 de fevereiro de 1998. 
Filha amada, a ti dedico todas as minhas conquistas!! Você é a minha parte mais bonita, a minha fortaleza, o meu amor inesgotável!! 


\section{AGRADECIMENTOS}

À minha orientadora Dra. Lourdes Isaac por ter me aceitado em seu laboratório e pela confiança em meu trabalho. Muito obrigada por sua amizade, pelos conselhos de mãe, pela generosidade e por ter me dado a oportunidade de amadurecer profissionalmente. Este período de aprendizado foi essencial para a minha formação cientifica, no qual recebi um conhecimento que vou levar por toda a minha vida acadêmica.

Aos meus pais e minhas irmãs Adriana, Fernanda por terem sempre me incentivado ao estudo, pelo amor incondicional, por toda a força e o apoio que vocês me deram, sempre!! Tenho muito orgulho de fazer parte da nossa família!! Adriana, obrigada minha irmã querida, sei que você está comigo em todos os momentos da minha vida!!

À Denise minha grande amiga a quem eu considero minha irmã de coração. Obrigada por todos os momentos que passamos juntas, pelos conselhos, pelo cuidado, pela atenção. Só nós duas nos conhecemos de verdade. Você é muito especial pra mim, te amo pra sempre!!

Às minhas queridas amigas Tati e Jéssica, pela confiança, pela grande amizade, por tudo o que vocês fizeram e fazem por mim sempre. Sem vocês, eu não teria conseguido nem a metade!! Muito obrigada pelo carinho, pelo apoio e pelos grandes momentos de alegria que compartilhamos!! Amo vocês!!

Às queridas amigas do laboratório Júlia, Priscilla, Catarina, Anielle, Helena e ao nosso querido IC Leo, pela amizade, pelo apoio constante, pelas risadas e por todos os momentos especiais que pudemos vivenciar juntas!!

À Dra. Angela Barbosa, pelo conhecimento transmitido, pela generosidade, pelo carinho, e pela grande ajuda neste projeto. Às meninas do Laboratório de Bacteriologia do Instituto Butantan, Ludmilla e Lidia pelo carinho e amizade.

Aos pesquisadores e funcionários do Laboratório de Zoonoses Bacterianas da Faculdade de Medicina Veterinária da USP: Dr. Sílvio Arruda Vasconcellos e Gisele O. Souza pelo fornecimento de culturas de leptospiras utilizadas neste trabalho.

À Marlene P. C. Florido, Claudinha e Raquel por todo o suporte técnico, pela amizade e por toda ajuda fornecida na realização deste projeto. 
Aos nossos vizinhos de laboratório: Marina, Nuria, Leandro, Cris, Tábata, Renata, Edgar, Zé Antônio, Lucila pela amizade, pelas risadas e pelos momentos de alegria no anexo.

Aos Professores do Departamento de Imunologia pela ajuda e por todo o conhecimento transmitido durante as aulas.

Aos amigos do Departamento de Imunologia, pela amizade, pelas palavras de carinho, pelo apoio nos momentos difíceis.

Aos funcionários do Departamento de Imunologia Milton, Otacílio, Moisés, Eni, Aurea pela disponibilidade de sempre, pelo carinho e amizade!!

Ao CNPq pelo auxílio financeiro fornecido para a execução deste projeto.

À todas as pessoas que estiveram comigo durante todo esse período, muito obrigada!! Cada um de vocês fazem parte da minha história. 
"No meio da confusão encontre a simplicidade. A partir da discórdia, encontre a harmonia. No meio da dificuldade reside a oportunidade".

Albert Einstein 


\section{RESUMO}

Amamura TA. Clivagem de Proteínas do Complexo de Ataque à Membrana do Sistema Complemento Humano por Proteases de Leptospiras Patogênicas. [dissertação (Mestrado em Imunologia)]. São Paulo: Instituto de Ciências Biomédicas, Universidade de São Paulo; 2016.

A leptospirose é uma zoonose causada por bactérias espiroquetas que pertencem ao gênero Leptospira. Muito frequente em áreas tropicais e subtropicais, a doença representa um grave problema de saúde pública. Nos últimos anos, diversas pesquisas envolvendo fatores relacionados à patogênese da leptospirose vêm sendo realizadas. Leptospiras patogênicas possuem a habilidade de escapar do Sistema Complemento humano, sendo capazes de sobreviver quando em contato com soro humano normal. Em um estudo anterior realizado por nosso grupo foi observado que sobrenadantes de leptospiras patogênicas inibem as três vias de ativação do Sistema Complemento. Tal atividade inibitória está diretamente relacionada à atividade de proteases secretadas, as quais são capazes de clivar as seguintes moléculas do Complemento: C3, assim como seus fragmentos C3b e iC3b, Fator B (Via Alternativa), C4 e C2 (Via Clássica e das Lectinas). Neste trabalho, expandimos a análise da atividade das proteases secretadas por leptospiras patogênicas sobre os componentes da Via Terminal do Sistema Complemento, denominado Complexo de Ataque à Membrana (MAC). Nos ensaios realizados, verificamos que proteases presentes nos sobrenadantes de cultura de diferentes espécies e estirpes patogênicas de leptospiras foram capazes de clivar as proteínas C6, C7, C8 e C9 do MAC, ao passo que as não patogênicas não apresentaram atividade proteolítica significante sobre estes substratos. As clivagens dessas moléculas do MAC ocorreram de forma tempo-dependente e de modo seletivo, uma vez que, mesmo utilizando quantidades reduzidas de sobrenadantes, ainda foi possível observar a geração de produtos de clivagem das proteínas do Complemento. Tais clivagens foram observadas em C6, C7, C8 e C9 quando purificadas, mas não quando o soro humano normal foi utilizado, possivelmente pela presença de inibidores em elevada concentração. Observamos também que as proteases secretadas pelas leptospiras patogênicas foram capazes de clivar o complexo solúvel SC5b-9, o qual possui atividade pró-inflamatória e pode atuar diretamente no endotélio. Ensaios utilizando inibidores de protease revelaram uma inibição da atividade proteolítica pela 1,10-fenantrolina, indicando a participação de metalo proteases. Dentre estas, conseguimos comprovar a atividade proteolítica da Termolisina recombinante LIC13322, uma metalo protease expressa exclusivamente por estirpes patogênicas de leptospira. A Termolisina recombinante foi capaz de clivar o componente $\mathrm{C} 6$, tanto isolado quanto como parte integrante do complexo SC5b-9. Além disso, verificamos que as proteínas do MAC são capazes de interagir com a Termolisina recombinante, indicando que esta protease pode exercer um efeito inibitório adicional sobre estas moléculas por um possível mecanismo de inibição por interação direta. Por fim, um ensaio funcional comprovou o efeito inibitório da Termolisina recombinante, a qual foi capaz de inibir a formação do MAC sobre eritrócitos de carneiro. Deste modo, podemos concluir que proteases secretadas por leptospiras patogênicas são capazes de degradar moléculas efetoras do Sistema Complemento, representando potenciais alvos para o desenvolvimento de novas terapias e estratégias profiláticas em leptospirose.

Palavras-chave: Leptospira. Evasão Imune. Sistema Complemento. Proteases. MAC. TC 


\begin{abstract}
Amamura TA. Cleavage of Membrane Attack Complex proteins of human Complement System by pathogenic leptospires proteases. [Masters thesis (Immunology)]. São Paulo: Instituto de Ciências Biomédicas, Universidade de São Paulo; 2016.

Leptospirosis is a zoonosis caused by spirochetes from the genus Leptospira. The disease is common in tropical and subtropical areas, constituting is a serious public health problem. In recent years, several studies related to the pathogenesis of leptospirosis have been carried out. Pathogenic Leptospira have the ability to escape the human Complement System, being able to survive when in contact with normal human serum. In a previous study, our group demonstrated that supernatants of pathogenic Leptospira inhibit the three activation pathways of the Complement System. This inhibitory activity can be directly associated to the activity of secreted proteases, which are capable of cleaving the following Complement molecules: $\mathrm{C} 3$, as well as the fragments $\mathrm{C} 3 \mathrm{~b}$ and $\mathrm{iC} 3 \mathrm{~b}$, Factor B (Alternative Pathway), C4 and C2 (Classical and Lectin Pathways). In this work, we analyze the activity of the leptospiral proteases on the components of Terminal Pathway of Complement, called Membrane Attack Complex (MAC). We observed that proteases present in the culture supernatants of pathogenic Leptospira strains were capable of cleaving the proteins C6, C7, C8 and C9, while the nonpathogenic strains had no significant proteolytic activity on these substrates. The cleavages occurred in a time-dependent manner and in a selective way, since even when reduced quantities of supernatants were used, the cleavage products were still observed. We only observed cleavage products when purified proteins (C6-C9) but not whole serum was used, probably because of presence of proteases inhibitors, such as alpha-2-macroglobulin, in elevated concentrations. We also verify that the leptospiral secreted proteases were able to cleave the soluble complex SC5b-9, which has proinflammatory activity and may act directly on the endothelium. Assays using protease inhibitors have shown an inhibition of the proteolytic activity by 1.10-phenanthroline, indicating the involvement of metalloproteases in the cleavages. In this context, we decided to analyze the proteolytic activity of Thermolysin a metalloprotease expressed exclusively by pathogenic Leptospira strains. Recombinant Thermolysin was capable of cleaving the component C6, either purified or as part of the SC5b-9 complex. Furthermore, we found that the MAC proteins are able to interact with Thermolysin, indicating that this protease may have an additional inhibitory effect on these molecules by a possible mechanism of direct interaction. Finally, a functional assay demonstrated the inhibitory effect of Thermolysin, which was able to inhibit the MAC formation on the surface of sheep erythrocytes. From this work, we can conclude that proteases produced exclusively by pathogenic Leptospira strains are capable of degrading Complement effector molecules, representing potential targets for the development of new therapies and prophylactic approaches in leptospirosis.
\end{abstract}

Keywords: Leptospira. Immune Evasion. Complement System. Proteases. MAC. TCC. 


\section{LISTA DE ILUSTRAÇÕES}

Figura 1 - $O$ ciclo de transmissão da leptospirose.

Figura 2 - Microscopia eletrônica de varredura da Leptospira interrogans sorovar Icterohaemorrhagiae.

Figura 3 - Análise filogenética com base nas sequências rRNA 16S de Leptospira spp.

Figura 4 - Ativação do Sistema Complemento Humano. 28

Figura 5 - Representação esquemática das proteínas que compõe o MAC e formação do complexo.

Figura 6 - A secreção de proteases pelas leptospiras patogênicas constitui um mecanismo de evasão imune ao Sistema Complemento

Figura 7 - Espécies $\mathrm{e}$ Estirpes de leptospiras utilizadas neste

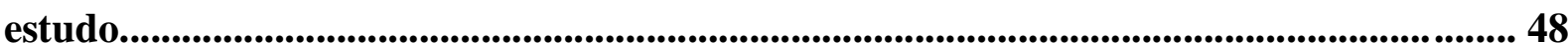

Figura 8 - Proteases secretadas por leptospiras patogênicas clivam proteínas do MAC 58

Figura 9 - As proteases secretadas pelas leptospiras patogênicas clivam proteínas do MAC mesmo em quantidades reduzidas. 60

Figura 10 - Proteases secretadas por leptospiras patogênicas clivam as proteínas C6 e C7 purificadas, de modo tempo dependente.

Figura 11 - Proteases secretadas por leptospiras patogênicas clivam as proteínas C8 e C9 purificadas, de modo tempo-dependente.

Figura 12 - $\mathrm{O}$ inibidor 1,10-fenantrolina apresenta atividade inibitória sobre proteases secretadas por leptospiras patogênicas. 65

Figura 13 - Análise da atividade proteolítica dos sobrenadantes das leptospiras utilizando SHN como fonte das proteínas do MAC.

Figura 14 - Análise da atividade inibitória da a2-macroglobulina sobre as proteases secretadas pelas leptospiras patogênicas utilizando as proteínas do MAC purificadas como substrato .68

Figura 15 - Análise da atividade proteolítica das proteases presentes nos sobrenadantes das leptospiras patogênicas sobre o complexo SC5b-9 por Western Blot.. 70

Figura 16 - Análise da atividade proteolítica das proteases presentes nos sobrenadantes das leptospiras patogênicas sobre o complexo SC5b-9 
Figura 17 - Representação esquemática da Termolisina codificada pelo gene LIC13322 de L. interrogans sorovar Copenhageni.......................................................................... 73

Figura 18 - A Termolisina recombinante possui atividade proteolítica sobre componente C6 do MAC, tanto na forma purificada quanto como parte integrante do complexo

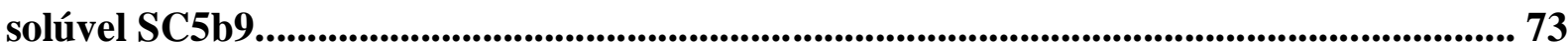

Figura 19 - A Termolisina recombinante não possui atividade proteolítica sobre os

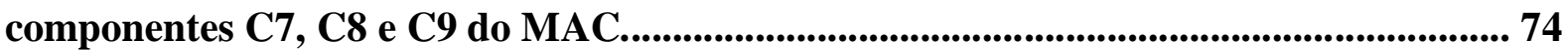

Figura 20 - A Termolisina recombinante interage com o componente C6 do

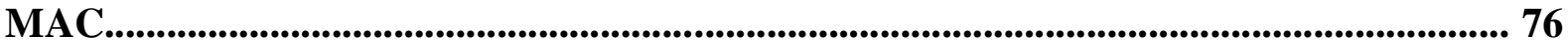

Figura 21 - A interação da Termolisina com o componente C6 do MAC é dependente de força iônica e é afetada pela adição de heparina..................................................................... 77

Figura 22 - A Termolisina interage com os componentes C7, C8 e C9 do

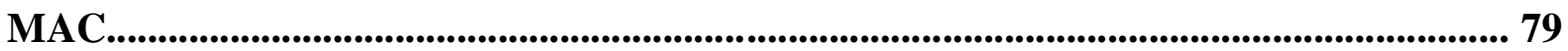

Figura 23 - A Termolisina inibe a formação do MAC de forma concentração

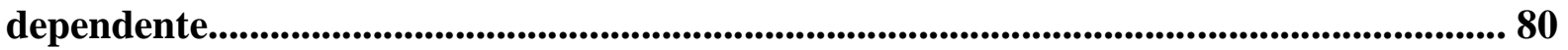

Figura 24 - Representação esquemática da atuação das proteases secretadas pelas leptospiras patogênicas sobre as proteínas do Sistema

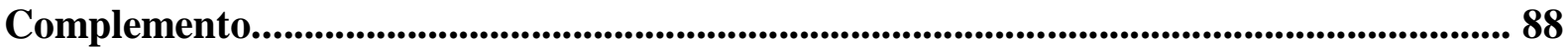




\section{LISTA DE TABELAS}

Tabela 1 - Inibidores de proteases utilizados nos ensaios de

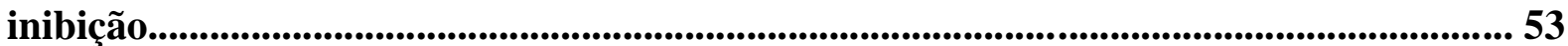




\section{LISTA DE ABREVIATURAS E SIGLAS}

$\mathbf{C a}^{++}$- Cálcio

C4BP - C4b Binding Protein

E. coli - Escherichia coli

ELISA - Enzyme-Linked Immunosorbent Assay

EMJH - Ellinghausen-McCullough/Johnson-Harris

E-64 - [1-[N-[(L-3-trans-carboxioxirano-2-carbonil)-L-leucil]amino]-4guanidinobutano]

FB - Fator B

FD - Fator D

FI - Fator I

FP - Properdina

LcpA - Leptospiral complement regulator-acquiring protein A

Lig - Leptospiral immunoglobulin-like protein

LigA - Leptospiral immunoglobulin-like protein A

LigB - Leptospiral immunoglobulin-like protein B

L. biflexa - Leptospira biflexa

L. interrogans - Leptospira interrogans

LipL32 - Leptospiral Lipoprotein 32

LPS - Lipopolissacarídeo

MAC - Complexo de Ataque à Membrana

MASP - Serino protease associado à MBL

MAT - Teste de Aglutinação Microscópica

MBL - Lectina ligadora de manose

$\mathbf{M g}^{++}$- Magnésio

PMSF - Fluoreto de fenilmetilsulfonilo

PVDF - Difluoreto de polivinilideno

SDS - Dodecil sulfato de sódio

SDS-PAGE - Eletroforese em gel de poliacrilamida contendo SDS

SHN - Soro humano nornal 


\section{SUMÁRIO}

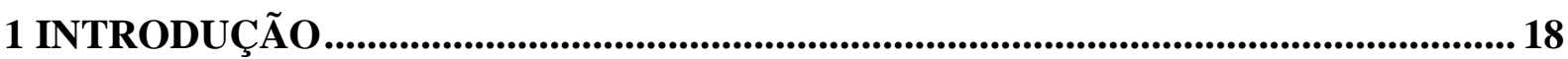

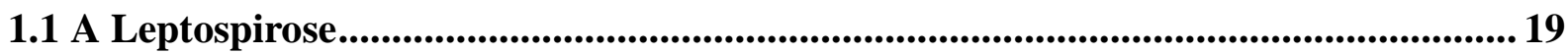

1.2 As leptospiras ....................................................................................................................... 23

1.3 O Sistema Complemento............................................................................................................ 26

1.4 Funções do Complemento ............................................................................................. 29

1.5 MAC .............................................................................................................................. 31

1.6 Moléculas que compõem o MAC ......................................................................................32

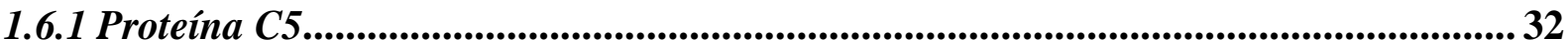

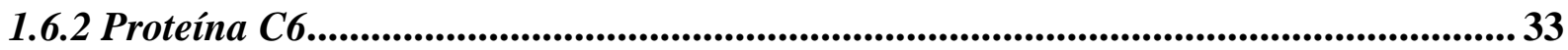

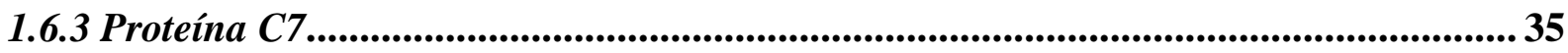

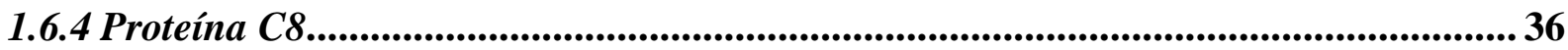

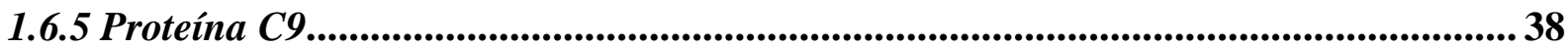

1.7 Reguladores da Formação do MAC …………………...........................................................39

1.8 Mecanismos de evasão ao Sistema Complemento ................................................................ 40

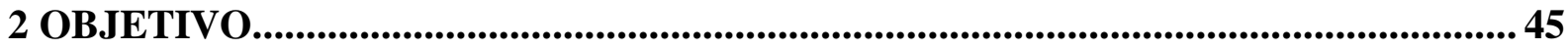

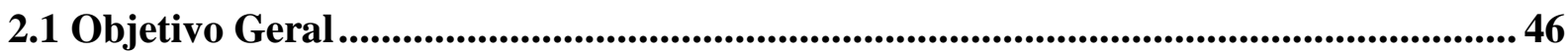

2.2 Objetivos específicos .................................................................................................................. 46

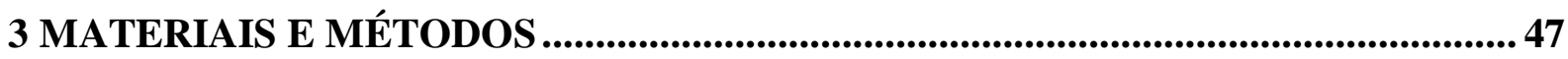

3.1 Espécies de leptospiras e condições de cultivo...................................................................... 48

3.2 Obtenção dos sobrenadantes de cultura de leptospiras .................................................... 48

3.3 Proteínas do complemento e anticorpos ..................................................................................49

3.4 Análise da atividade proteolítica de diferentes sobrenadantes de leptospiras sobre as proteínas C6-C9 do MAC ..................................................................................................... 49

3.5 Análise das clivagens das proteínas C6-C9 por Western Blot .......................................... 49

3.6 Análise da eficiência proteolítica dos sobrenadantes de cultura das leptospiras sobre os componentes do MAC ............................................................................................................51

3.7 Avaliação da atividade enzimática das proteases secretadas por leptospiras em função do tempo de reação .........................................................................................................51 
3.8 Avaliação da atividade proteolítica dos sobrenadantes de cultura das leptospiras sobre o complexo solúvel SC5b-9 purificado

3.9 Análise da atividade proteolítica dos sobrenadantes de cultura de leptospiras utilizando soro humano normal (SHN) como fonte de proteínas do MAC

3.10 Determinação das classes de proteases envolvidas nas clivagens das proteínas do MAC.

3.11 Análise da atividade proteolítica da Termolisina sobre os componentes do MAC e complexo solúvel SC5b-9

3.12 Análise da interação da Termolisina com as proteínas do MAC por Western blot com sobreposição e ELISA ................................................................................................................. 53

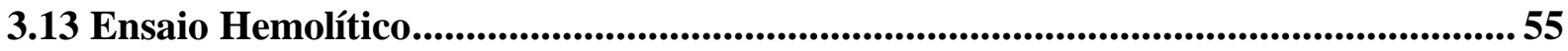

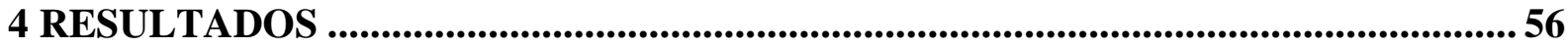

4.1 Avaliação da atividade proteolítica dos sobrenadantes de leptospiras sobre as proteínas C6-C9 purificadas ...................................................................................................5 57

4.2 Análise da eficiência proteolítica das proteases secretadas pelas leptospiras patogênicas sobre as proteínas que compõem o MAC...........................................................5 59

4.3 Avaliação da atividade proteolítica dos sobrenadantes das leptospiras sobre os componentes do MAC em diferentes tempos de reação ...........................................61

4.4 Determinação das classes de proteases secretadas pelas leptospiras patogênicas que clivam as proteínas C6-C9 do MAC ..........................................................................6 64

4.5 Avaliação da atividade proteolítica dos sobrenadantes de leptospiras patogênicas utilizando SHN como fonte das proteínas do MAC ........................................................... 66

4.6 Avaliação da atividade proteolítica dos sobrenadantes das culturas de leptospiras sobre o complexo SC5b-9............................................................................................ 69

4.7 Análise da atividade proteolítica da Termolisina sobre os componentes C6-C9 purificados e o complexo solúvel SC5b-9 ............................................................................ 72

4.8 Análise da interação da Termolisina com o componente C6 do MAC........................ 75

4.9 Análise da interação da Termolisina recombinante com os componentes C7, C8 e C9

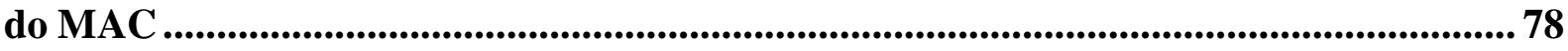

4.10 Análise da capacidade da Termolisina em inibir a formação do MAC....................80 


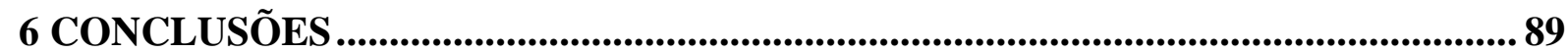

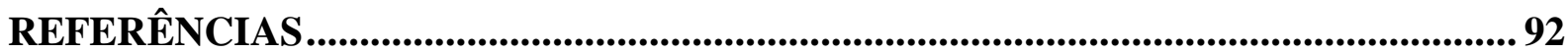


1 INTRODUÇÃO 


\subsection{A Leptospirose}

A leptospirose é uma importante zoonose de origem bacteriana. Essa doença que é reconhecida como um grave problema de saúde pública é causada por bactérias do gênero Leptospira que incluem espécies patogênicas, intermediárias e saprófitas (não-patogênicas) (Ko et al., 2009). O número de novos casos de leptospirose é estimado em 1 milhão a cada ano, com cerca de 58.900 mortes em todo o mundo (Costa et al., 2015).

A elevada prevalência da doença é observada principalmente em locais de clima tropical devido a maior sobrevida das bactérias em climas quentes e úmidos. Os grupos populacionais mais afetados são aqueles expostos a condições de saneamento básico inadequado. Estas situações agravam-se onde há enchentes frequentes, propiciando a disseminação das leptospiras no ambiente. Profissionais que desempenham funções ocupacionais associadas a trabalhos ao ar livre como coletores de lixo, agricultores, militares do exército, veterinários, que estão expostos ao contato direto com animais infectados, são potenciais alvos para contraírem a leptospirose. Além disso, atividades recreativas como esportes aquáticos também são consideradas condições propícias para se contrair a doença (Levett, 2001).

A doença é transmitida pelo contato direto com a urina de animais infectados ou indiretamente por água e solo contaminados com leptospiras (Figura 1). Animais domésticos e selvagens podem ser reservatórios, sendo os roedores considerados os principais transmissores (Schreier et al., 2009). As leptospiras colonizam os túbulos renais proximais destes animais, sendo posteriormente liberadas na urina (Adler, de la Peña Moctezuma, 2009).

Seres humanos são considerados hospedeiros acidentais, infectando-se pela penetração das leptospiras através de mucosas, da pele lesada ou íntegra, a qual ocorre somente em condições específicas que favoreçam a dilatação dos poros, tais como a permanência por tempo prolongado em água contaminada. Após a penetração no hospedeiro, há disseminação das bactérias via circulação sanguínea sendo rapidamente estabelecida a infecção sistêmica (Levett, 2001). 
Sintomas Clínicos: Hemorragia Pulmonar Disfunção renal e hepática
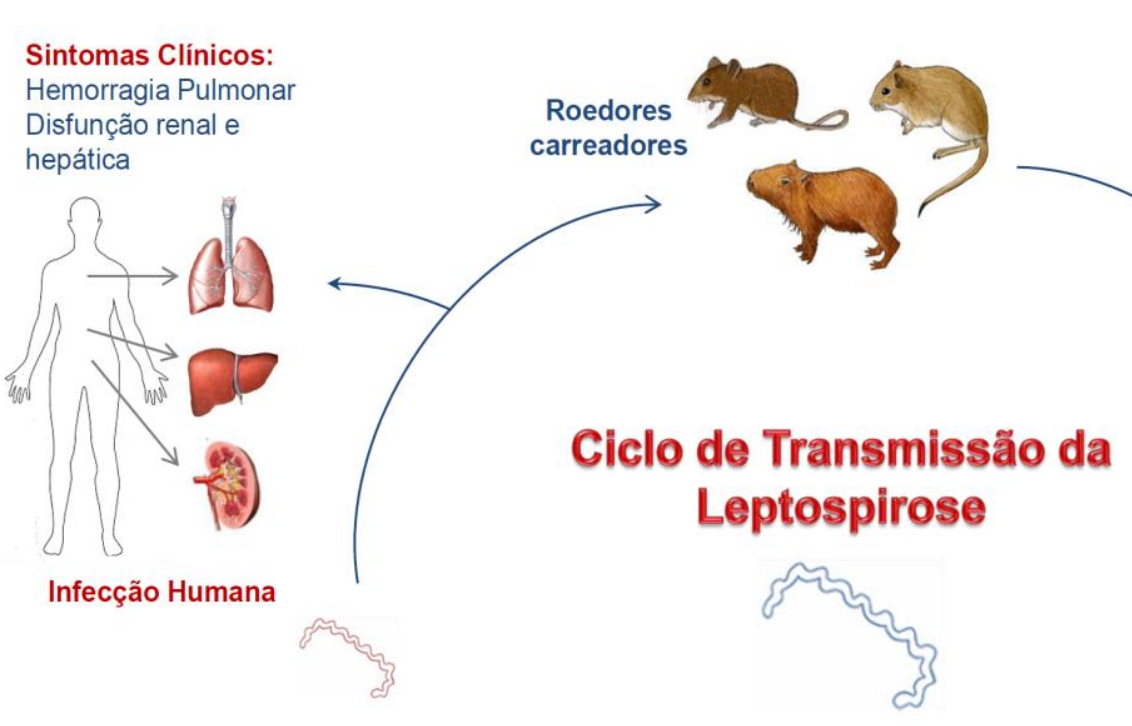

Infecção Humana

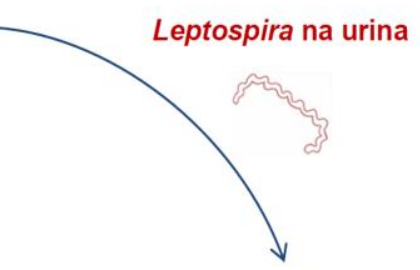

urina e órgãos

Fatores de

Risco:

Trabalho em

fazendas e

abatedouros

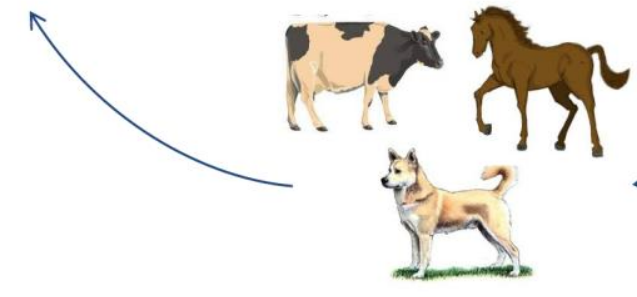

Mamíferos reservatórios (animais domésticos e selvagens)

Figura 1 - O ciclo de transmissão da leptospirose. Os principais reservatórios das leptospiras patogênicas são os roedores, os mamíferos domésticos e selvagens. As bactérias são eliminadas na urina destes animais e contaminam a água e o solo. Em roedores, a leptospirose apresenta-se como uma infecção crônica e assintomática. Já em mamíferos, podem ocorrer diferentes manifestações tais como abortos em bovinos e uveíte em cavalos. A manutenção da leptospirose nestes animais ocorre pela transmissão interna dentro dos rebanhos ou pelo contato contínuo com roedores. Os humanos são hospedeiros acidentais e podem ser infectados pelo contato direto com animais ou com a água e solo contaminados. As principais manifestações clínicas da forma grave da doença incluem hepatite, nefrite e hemorragia pulmonar. Os humanos não são considerados reservatórios de leptospiras, uma vez que não eliminam uma quantidade de bactérias suficiente para a transmissão (Fraga et al., 2014a). 
A leptospirose é descrita como uma doença bifásica. Na fase aguda da doença, as leptospiras patogênicas são encontradas na corrente sanguínea e persistem no organismo do hospedeiro infectado por cerca de 3 a 10 dias. A segunda fase inicia-se com a produção de anticorpos específicos e eliminação de leptospiras na urina com duração de 10 a 30 dias (Levett, 2001).

Manifestações clínicas muito variáveis podem ser observadas durante a infecção por leptospiras. A gravidade da doença varia de acordo com o sorovar infectante, tamanho do inóculo, a idade e o estado de saúde do paciente (Evangelista, Coburn, 2010). Na fase aguda da infecção, o quadro clínico assemelha-se ao da gripe com sintomas como febre, cefaleia, mialgia, náuseas e vômitos. Contudo, a doença pode evoluir para formas sistêmicas graves como a Síndrome de Weil, caracterizada por icterícia, insuficiência renal, comprometimento hepático e pulmonar. A síndrome pulmonar hemorrágica vem sendo reconhecida como uma manifestação distinta que ocorre na fase tardia da leptospirose. Os pacientes expressam sintomas como tosse, dispneia e hemoptise, os quais são associados a anormalidades radiográficas que indicam a presença de infiltrado intersticial e até densa hemorragia pulmonar apresentando mortalidade superior a 50\% dos casos relatados (Levett, 2001; Spichler et al., 2008).

Manifestações oculares têm sido relatadas em infecções por leptospirose. A uveíte é uma grave complicação da doença que pode ocorrer após fase aguda da infecção, causando cegueira em humanos e principalmente em cavalos. Um grande número de casos de uveíte foi notificado após um surto de leptospirose seguido por inundações na Índia. Hemorragia subconjuntival, edema papilar e neurite óptica são outras significativas manifestações clínicas causadas pela leptospirose na região dos olhos (Bharti et al., 2003).

Devido à grande diversidade de sinais clínicos, o diagnóstico da leptospirose pode ser confundido com outras doenças que apresentam sintomas semelhantes. O teste de aglutinação microscópica (MAT) é considerado o padrão-ouro de diagnóstico (Palaniappan et al., 2007). Contudo, este método apresenta algumas limitações, pois é demorado e exige um conhecimento laboratorial especializado. O MAT é realizado a partir de duas amostras de soro de pacientes, coletadas com duas semanas de intervalos entre elas (Kitashoji et al., 2015). O teste é sensível e específico para a detecção de anticorpos anti-leptospiras em humanos. Neste teste, soros de pacientes reagem com suspensões de leptospiras vivas ou inativadas representantes de sorovares de uma determinada localidade. Após a incubação, a suspensão é analisada por microscopia óptica de campo escuro para determinação do título de aglutinação de leptospiras (Levett, 2001). 
A determinação do título de anticorpos específicos no soro de pacientes é feita por ELISA. Nesta técnica são utilizados diferentes antígenos, tais como proteínas recombinantes como lipoproteína de $32 \mathrm{kDa}$ (LipL32), Leptospiral immunoglobulin-like protein A (LigA) ou outer membrane protein L1 (OmpL1) (Fraga et al., 2014a). Diversos autores têm descrito que anticorpos contra leptospiras podem ser detectados mais precocemente por ELISA, quando comparados ao MAT, por ser o primeiro método mais sensível detectando $\operatorname{IgM}$ específicas já com 4 a 5 dias após o surgimento dos sintomas, anterior à detecção dos anticorpos $\operatorname{IgG}$ aglutinantes, e persistindo pelo menos 5 meses no paciente. Recentemente, tem sido desenvolvido protocolos de detecção de $\operatorname{IgM}$ em diferentes formatos de teste rápido para utilização em laboratórios. (Cumberland et al., 1999; Goris, 2013; Picardeau, 2013).

A identificação de leptospiras por cultura utilizando amostras de sangue, urina ou tecidos representa um diagnóstico definitivo. Contudo, uma desvantagem dessa metodologia é a lenta taxa de crescimento dessas bactérias, necessitando um longo período de incubação (Adler, de la Peña Moctezuma, 2009). Nos últimos anos, a reação em cadeia empregando DNA polimerase (PCR) tem sido cada vez mais utilizada para o diagnóstico de leptospirose e tende a substituir os métodos sorológicos em zonas endêmicas devido a sua sensibilidade, capacidade de diferenciar espécies patogênicas e não-patogênicas e promover um diagnóstico precoce (Bharti et al., 2003; Picardeau, 2013).

O tratamento da leptospirose depende da persistência dos sintomas e seriedade da doença. Para casos leves e moderados a doxaciclina é o antibiótico mais recomendado. Já a penicilina, ampicilina ou cefalosporina são indicadas para os quadros mais graves da doença (Ricaldi et al., 2013).

Para prevenir a leptospirose humana, vacinas estão disponíveis apenas em alguns países tais como Rússia, Cuba, França e Japão, os quais apresentam populações de risco para a infecção. Contudo, há certas limitações no seu uso. As primeiras vacinas produzidas por meio de suspensões de leptospiras mortas em meio contendo soro, apresentaram um perfil de efeitos colaterais como dores, náusea e febre. Além disso, sua eficácia é de curta duração, devendo ser repetida anualmente para conferir proteção. A vacina é sorovar-específica, e portanto, a imunidade é gerada somente contra os sorovares localmente predominantes (Levett, 2001).

A busca de vacinas com antígenos amplamente conservados entre os sorovares e com menos efeitos adversos é uma importante frente de pesquisa em leptospirose. Diversos estudos relacionados com proteínas de membrana externa de leptospira têm sido realizados, em especial com as proteínas Ligs. Tais proteínas são expressas por cepas virulentas, mas não 
em espécies saprófitas ou em culturas atenuadas de leptospiras e são capazes de induzir a produção de anticorpos específicos em pacientes e animais infectados (Silva et al., 2007). As Ligs têm sido consideradas ótimas candidatas vacinais para leptospirose, conferindo proteção em modelos animais. Diferentes fragmentos da proteína LigA foram capazes de conferir $100 \%$ de proteção em modelo experimental empregando hamster. No entanto, estudos adicionais são necessários para prevenir a colonização renal, uma vez que esses animais continuaram sendo portadores da bactéria (Faisal et al., 2008; Forster et al., 2013; Palaniappan et al., 2006).

\subsection{As leptospiras}

O gênero Leptospira pertence à família Leptospiraceae e à ordem Spirochaetales (Faine et al., 1999). As leptospiras são bactérias finas e espiraladas com extremidades em forma de gancho e elevada motilidade em virtude da presença de dois flagelos periplasmáticos, responsáveis por movimentos de rotação e translação (Figura 2) (Levett, 2001). Estruturalmente, estas bactérias apresentam dupla membrana e parede celular de peptideoglicano intimamente associada à membrana citoplasmática (Adler, de la Peña Moctezuma, 2010).

A estrutura do lipopolissacarídeo (LPS) das leptospiras é semelhante ao encontrado em bactérias Gram-negativas. Em bactérias patogênicas como L. interrogans, o LPS estendese $9,2 \mathrm{~nm}$ a partir do folheto externo, enquanto que na saprófita $L$. biflexa ele se encontra presente em uma camada mais fina de 6,0 nm. Fosfolipídeos, proteínas da membrana externa e LPS são os principais componentes da membrana externa que permitem a troca de solutos entre o espaço periplasmático e o meio ambiente (Evangelista, Coburn, 2010; Ko et al., 2009; Raddi, 2012).

A bactéria patogênica $L$. interrogans sobrevive em diferentes ambientes como na água e em hospedeiros mamíferos. Esta espiroqueta é capaz de manter a motilidade em condições de osmolaridade fisiológica (cerca de $150 \mathrm{mM}$ de $\mathrm{NaCl}$ ), enquanto a saprófita $L$. biflexa perde sua motilidade nestas condições. O fato de leptospiras patogênicas suportarem alterações osmóticas preservando a sua motilidade sugere que esta espécie possui uma vantagem durante a migração no hospedeiro em comparação com as espécies saprófitas, ressaltando a importância da relação entre motilidade e virulência destas bactérias (Takabe et al., 2013). 
As leptospiras são bactérias aeróbicas obrigatórias com temperatura ótima para crescimento entre $28{ }^{\circ} \mathrm{C}$ e $30^{\circ} \mathrm{C}$. Em contraste com as espécies patogênicas, as leptospiras saprófitas também são capazes de se multiplicar em temperaturas mais baixas $\left(11 \mathrm{C}^{\circ}-13{ }^{\circ} \mathrm{C}\right)$. A faixa de $\mathrm{pH}$ ideal para o crescimento das leptospiras é 7,2 a 7,6. O tempo de crescimento de leptospiras patogênicas é estimado entre 14 e 18 h. Já as leptospiras saprófitas se multiplicam mais rapidamente, com tempo de crescimento aproximado de 4 a 5 h (Faine et al., 1999). O meio mais utilizado para o cultivo de leptospiras é o Ellinghausen-McCullough JohnsonHarris (EMJH), que é composto por ácido oleico, albumina de soro bovino e polissorbato (Tween) (Adler, de la Peña Moctezuma, 2010).

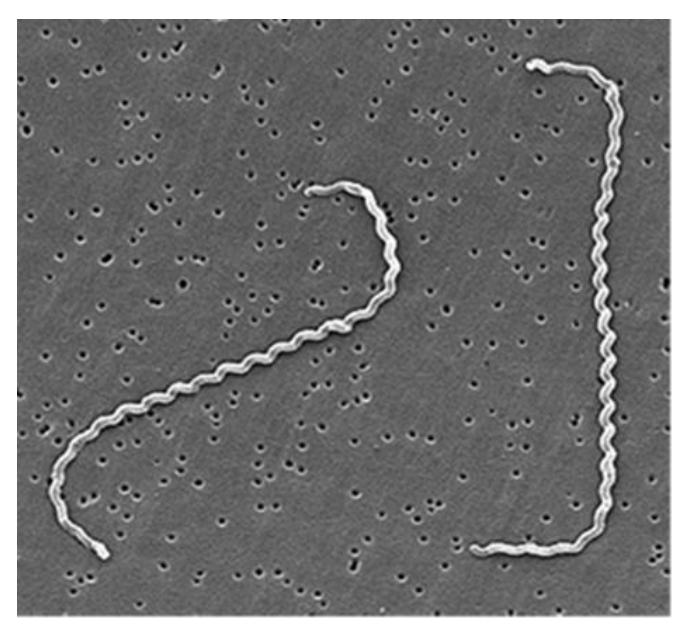

Figura 2 - Microscopia eletrônica de varredura da Leptospira interrogans sorovar Icterohaemorrhagiae. As leptospiras possuem aproximadamente $0,1 \mu \mathrm{m}$ de largura e $6 \mu \mathrm{m}$ a $20 \mu \mathrm{m}$ de comprimento. Os flagelos localizados em extremidades opostas da bactéria contribuem para que estas possuam o formato espiralado, conferindo a estas movimentos de rotação e translação (Levett, 2001).

O gênero Leptospira é formado por espécies patogênicas, não patogênicas e intermediárias. Atualmente são descritas 21 espécies de leptospiras (Faine et al., 1999). O teste de aglutinação cruzada permitiu a definição de sorovares os quais são distinguidos pela heterogeneidade estrutural das moléculas de LPS da bactéria fornecendo um importante instrumento para sua classificação. Atualmente mais de 300 sorovares são reconhecidos, porém esta lista tem sido periodicamente atualizada. Os sorogrupos são identificados pelo MAT e têm como propósito agrupar sorovares com antígenos em comum. Contudo, os sorogrupos não possuem classificação taxonômica oficial (Levett, 2001; Cerqueira e Picardeau, 2009). 
A estrutura filogenética determinada a partir da sequência do gene $r R N A 16 S$ está em concordância com a taxonomia clássica aceita para espiroquetas, na qual a ordem Spirochaetales está dividida em duas famílias: Spirochaetaceae e Leptospiraceae. A análise da sequência do rRNA $16 S$ é considerada o método mais preciso para determinar as relações filogenéticas, que identificam três grupos de leptospiras de acordo com a sua patogenicidade (espécies patogênicas, saprófitas e intermediárias) (Figura 3). Além do $r R N A 16 S$, outros genes foram utilizados para diferenciar as espécies que fazem parte do gênero Leptospira tais como rpoB, gyrB e ligB (Cerqueira, Picardeau, 2009; Levett, 2015; Paster et al., 1991).

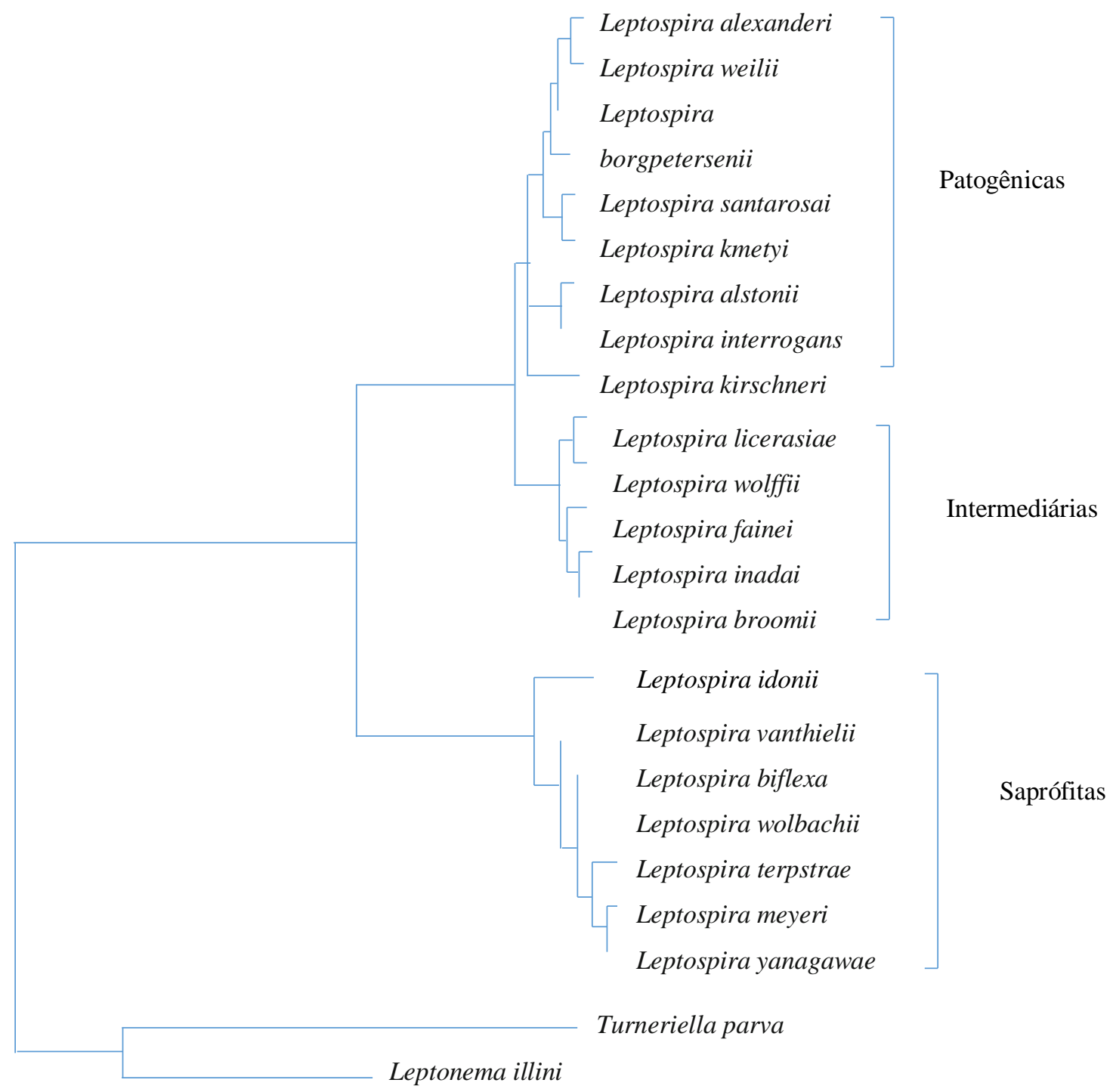

Figura 2 - Análise filogenética com base nas sequências $r R N A 16 S$ de Leptospira spp. As espécies de leptospiras são agrupadas como bactérias patogênicas, saprófitas e intermediárias. Recentemente, os genomas de Turneriella parva e Leptonema illini foram sequenciados (Levett, 2015). 


\subsection{O Sistema Complemento}

O Sistema Complemento é composto por mais de 40 proteínas plasmáticas ou associadas a membranas celulares. Esse complexo sistema faz parte da resposta imunológica do hospedeiro, contribuindo com importantes mecanismos efetores na defesa contra infecções, além de promover a remoção de células apoptóticas e de complexos imunes circulantes (Figura 4). O Sistema Complemento pode ser ativado por três vias distintas: Alternativa, Clássica e das Lectinas, que compreendem uma série de reações em cascata, culminando com a formação do Complexo de Ataque à Membrana (MAC), responsável pela lise celular (Lappegård et al., 2014; Walport, 2001).

A Via Alternativa pode ser ativada a partir da hidrólise espontânea da ligação tiól-ester da molécula de $\mathrm{C} 3$, gerando $\mathrm{C} 3\left(\mathrm{H}_{2} \mathrm{O}\right)$. Esta molécula, interage com o Fator B ( $\mathrm{FB}$ ) formando $\mathrm{C} 3\left(\mathrm{H}_{2} \mathrm{O}\right) \mathrm{B}$, permitindo a sua clivagem pelo Fator D (FD) resultando na primeira C3convertase da Via Alternativa: $\mathrm{C} 3\left(\mathrm{H}_{2} \mathrm{O}\right) \mathrm{Bb}$. Este complexo na presença de íons $\mathrm{Mg}^{++}$é capaz de clivar $\mathrm{C} 3$ em $\mathrm{C} 3 \mathrm{a}$ e $\mathrm{C} 3 \mathrm{~b}$. O fragmento $\mathrm{C} 3 \mathrm{~b}$ pode interagir com $\mathrm{FB}$ que será clivado posteriormente pelo FD gerando o complexo $\mathrm{C} 3 \mathrm{bBb}$, que por sua vez, é estabilizado pelo Fator P (FP) ou Properdina, uma molécula responsável por aumentar a meia vida das C3- e C5-convertases desta via. O complexo $\mathrm{C} 3 \mathrm{bBb}$ atua como segunda $\mathrm{C} 3$-convertase clivando mais moléculas de $\mathrm{C} 3$, o que pode resultar na formação do complexo $\mathrm{C} 3 \mathrm{bBbC} 3$ b denominado C5-convertase da Via Alternativa. Este complexo tem por finalidade, clivar moléculas de C5 em C5a e C5b, dando início à Via Terminal Comum do Sistema Complemento (Dunkelberger, Song, 2010; Tegla et al., 2011).

A ativação da Via Clássica ocorre principalmente pela interação de C1q do complexo $\mathrm{C} 1$ aos domínios $\mathrm{C}_{\mathrm{H}} 2$ de $\mathrm{IgG}$ ou aos domínios $\mathrm{C}_{\mathrm{H}} 3$ das moléculas de IgM ligadas a antígenos. $\mathrm{Na}$ ausência de anticorpos, outros substratos tais como proteína-C reativa, envelope viral, parede celular de bactérias Gram-negativas e mielina do sistema nervoso também podem ativar direto a Via Clássica. C1 é um complexo proteico grande e multimérico, composto pelas moléculas de $\mathrm{C} 1 \mathrm{q}, \mathrm{C} 1 \mathrm{r}_{2}$ e $\mathrm{C} 1 \mathrm{~s}_{2}$. C1q se liga à porção $\mathrm{Fc}$ dos anticorpos, induzindo a ativação das proteases $\mathrm{C} 1 \mathrm{r}$ e $\mathrm{C} 1 \mathrm{~s}$ na presença de $\mathrm{Ca}^{++}$. $\mathrm{C} 1$ s ativado é capaz de clivar a proteína $\mathrm{C} 4$ gerando os fragmentos $\mathrm{C} 4 \mathrm{~b}$ e $\mathrm{C} 4 \mathrm{a}$. O fragmento $\mathrm{C} 4 \mathrm{~b}$ pode se ligar covalentemente à superfície da célula alvo, assegurando que a ativação da Via Clássica prossiga. C2 liga-se ao $\mathrm{C} 4 \mathrm{~b}$ formando o complexo $\mathrm{C} 4 \mathrm{~b} 2$. C1s cliva $\mathrm{C} 2$ gerando os fragmentos $\mathrm{C} 2 \mathrm{~b}$ e $\mathrm{C} 2 \mathrm{a}$, este último permanece associado ao C4b. O complexo C4b2a é denominado C3-convertase da Via Clássica, com capacidade de clivar a molécula C3 em C3a e C3b. Sequencialmente, algumas 
moléculas de $\mathrm{C} 3 \mathrm{~b}$ geradas pela $\mathrm{C} 3$-convertase, podem se ligar à própria convertase formando o complexo C4b2a3b, que atua como a C5-convertase da Via Clássica, capaz de clivar a molécula C5 em C5a e C5b, dando início à etapa final de ativação do Sistema Complemento (Sarma, Ward, 2011; Tegla et al., 2011).

A ativação da Via das Lectinas inicia-se pela interação de carboidratos presentes em glicoproteínas e polissacarídeos microbianos com a lectina ligante de manose (MBL) ou ficolinas. Estas lectinas são proteínas solúveis que apresentam similaridade estrutural e funcional com C1q. MBL e ficolinas associam-se a serino proteases conhecidas por $M B L$ associated serine proteases (MASPs), incluindo MASP 1, MASP 2 e MASP 3. Uma vez que a MBL ou as ficolinas se ligam à manose, ocorre uma mudança conformacional em MASP 2 resultando em sua ativação. MASP 2 tem a capacidade de clivar C4 em C4a e C4b e C2 em C2a e C2b. Semelhantemente à Via Clássica, são gerados os complexos C4b2a com atividade de C3-convertase e C4b2a3b denominado C5-convertase da Via das Lectinas (Dunkelberger, Song, 2010; Tegla et al., 2011). MASP-1 parece ser importante para a ativação de MASP-2 e possivelmente de MASP-3. Esta serino protease é capaz de clivar uma série de substratos presentes no sangue humano, interagir com a cascata de coagulação e pode ativar células endoteliais estimulando a sinalização pró-inflamatória (Dobó et al., 2014). MASP-3 ativa FB no sangue demonstrando ser importante o seu envolvimento na interação entre as Vias Alternativa e das Lectinas (Dobó et al., 2016).

As C5-convertases geradas pelas Vias Clássica, Alternativa e das Lectinas clivam as moléculas C5, produzindo os fragmentos C5a e C5b. C5b inicia a Via Terminal e permite a subsequente associação das moléculas C6 e C7. O componente C7 do complexo C5b67 é hidrofóbico e se insere na bicamada lipídica da membrana. A interação de C8 leva à estabilidade do complexo C5b-7, sendo a formação completa do MAC finalizada pela associação de diversas moléculas de C9 ao complexo C5b-8 gerando C5b6789n. O MAC forma um poro na membrana plasmática, possibilitando a saída de íons e água. Consequentemente, este mecanismo gera um aumento de volume osmótico e ruptura celular (Walport, 2001). 


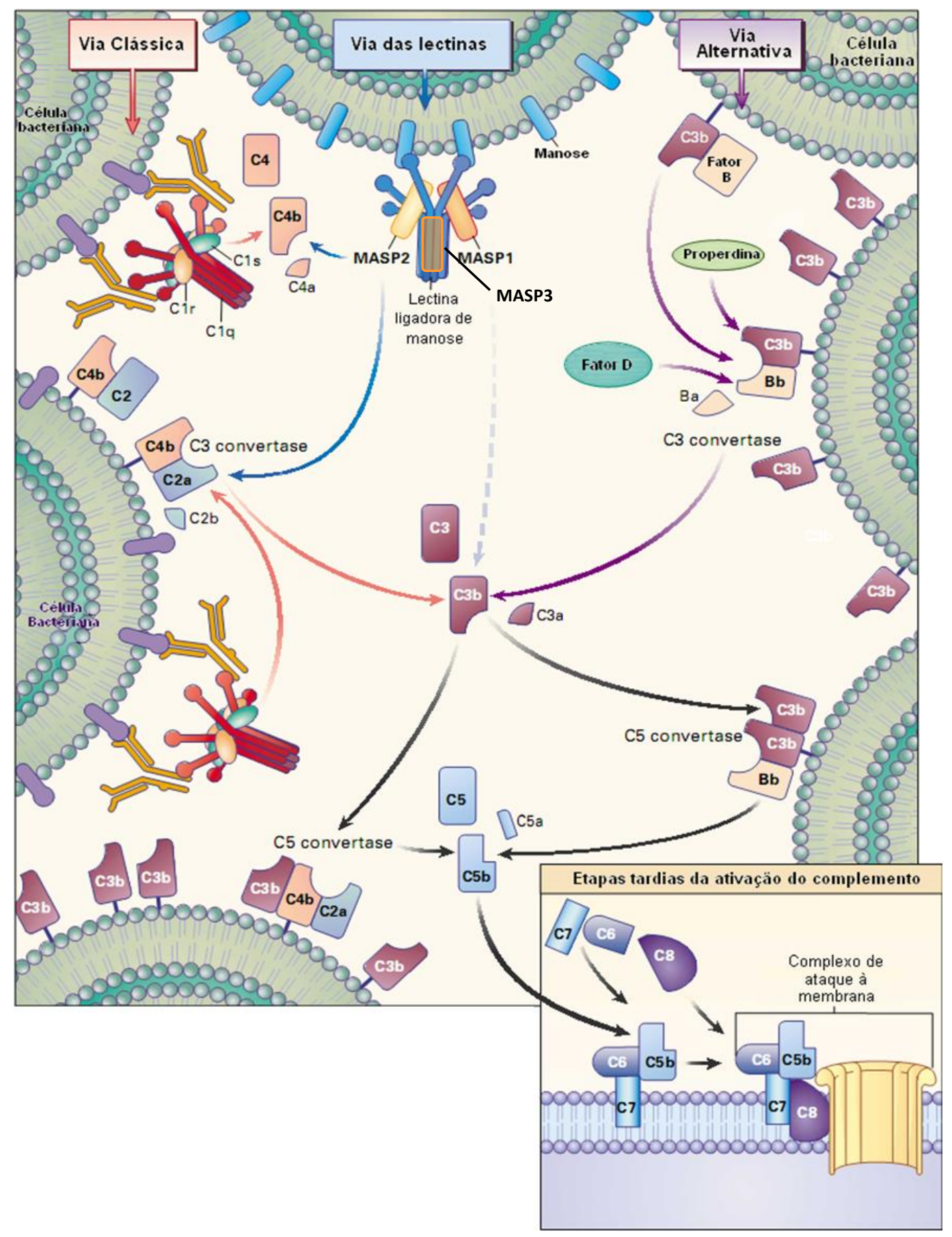

Figura 3 - Ativação do Sistema Complemento Humano. O Sistema Complemento pode ser ativado por três vias distintas: Clássica, Alternativa e das Lectinas. A Via Clássica é iniciada pela ligação do complexo $\mathrm{C} 1$ aos anticorpos ligados a antígenos presentes na superfície bacteriana. A Via das Lectinas é ativada por meio da ligação de MBL ou ficolinas a carboidratos na superfície de patógenos. Já a Via Alternativa é ativada após a ligação covalente de $\mathrm{C} 3 \mathrm{~b}$ à superfície de antígenos. As três vias do Complemento levam à formação de C5-convertases, capazes de clivar C5 em C5a e C5b, iniciando a Via Terminal do Sistema Complemento (Fonte: modificado de Walport, 2001). 


\subsection{Funções do Complemento}

O Complemento participa essencialmente de vários mecanismos efetores gerados durante a resposta imune inata e adaptativa (Revisado em Walport, 2001).

A opsonização é um dos mecanismos mais importantes que ocorrem durante a fase de ativação do Complemento, sendo os fragmentos $\mathrm{C} 3 \mathrm{~b}$, iC $3 \mathrm{~b}$ e $\mathrm{C} 4 \mathrm{~b}$ responsáveis por se ligarem covalentemente na superfície de diferentes patógenos. Esse processo de fagocitose pode ser facilitado mediante a interação dessas opsoninas com receptores específicos (CR1, CR3 e CR4) presentes nas superfícies de células fagocitárias como os neutrófilos e macrófagos (Revisado em Bohlson et al., 2014; Takizawa et al., 1996).

Os componentes C3a e C5a não se fixam aos patógenos e, assim que formados durante a ativação das cascatas do Complemento, são liberados localmente nos tecidos e na fase fluida, onde vão desempenhar diferentes funções que envolvem o recrutamento de células inflamatórias (fatores quimiotáticos) ou a estimulação de mastócitos e basófilos provocando sua desgranulação (anafilotoxinas) de mediadores inflamatórios (Daffern et al., 1995; Dias da Silva, Lepow, 1967; Klos et al., 2009). Além disso, a ativação do Sistema Complemento também é capaz de influenciar a vasodilatação, ativação de complexos inflamassomas e secreção de citocinas (Laudisi et al., 2013; Manthey et al., 2009).

O Complemento também desempenha importante papel na regulação da resposta imune humoral. O receptor de Complemento CR2 expresso em linfócitos B interage com as moléculas $\mathrm{C} 3 \mathrm{~d}$ e $\mathrm{iC} 3 \mathrm{~b}$ nas superfícies dos antígenos, desencadeando um aumento na sinalização da resposta celular. A interação entre CR2:C3d também envolve as células dendríticas foliculares, em que o aprisionamento de antígenos opsonizados por C3d via CR2, induz apresentação aos linfócitos B virgens, gerando células efetoras e de memória. C3d é um adjuvante molecular da resposta imune inata que influencia intensamente a produção de anticorpos (Dempsey et al., 1996; Fang et al., 1998; Revisado em Carrol, Isenman, 2012).

O Complemento também é responsável pela remoção de complexos imunes mediante a interação dos complexos fixados aos fragmentos C3b e C4b que se ligam a CR1 presente nos eritrócitos e demais células sanguíneas, sendo transportados posteriormente por essas células para órgãos (principalmente fígado) para eliminação desses complexos. Além disso, a eliminação de células apoptóticas ocorre principalmente por ação do componente C1q e outras proteínas do Complemento (Revisado em Ricklin et al., 2010; Takizawa et al., 1996). 
Finalmente, uma das funções mais drásticas do Complemento é a formação do MAC. Uma vez formado na superfície da membrana da célula alvo ou de patógenos, este complexo citolítico promove a entrada de íons e água causando lise (Müller-Eberhard, 1986). 


\subsection{MAC}

Durante o desenvolvimento da resposta imune inata, o Sistema Complemento atua como um dos mais importantes mecanismos de proteção do hospedeiro. Dentre suas funções, a lise mediada pelo MAC é evidenciada como um evento fundamental para uma resposta imune eficiente, sobretudo pela sua participação na eliminação de patógenos e células danificadas (Hadders, 2007).

As C5-convertases geradas pelas Vias Alternativa, Clássica ou das Lectinas iniciam a ativação dos componentes finais do Sistema Complemento, que culminam na formação do MAC composto pelas moléculas C5b, C6, C7, C8 e C9 (Podack et al., 1980).

O fragmento C5b pode interagir com as proteínas C6 e C7. O complexo C5b67 permite a incorporação da molécula de C8. Esta proteína é formada por três distintas subunidades: cadeias $\alpha, \beta$ e $\gamma$. Enquanto a cadeia $C 8 \beta$ é responsável pela ligação de $C 8$ ao complexo $\mathrm{C} 5 \mathrm{~b} 7$, a cadeia $\mathrm{C} 8 \alpha$ é a primeira proteína a penetrar nas membranas celulares. Para a formação completa do MAC, ainda se faz necessária a participação de diversas moléculas de C9, as quais interagem com o complexo C5b8, tendo como resultado a formação de um poro transmembranar. Como consequência, ocorre o influxo de água e íons, o que promove significativas alterações na permeabilidade da membrana, culminando na morte celular (Hadders, 2012).

O complexo solúvel SC5b-9 apresenta uma composição idêntica ao MAC, exceto pela presença de uma proteína reguladora plasmática chamada S-proteína ou vitronectina. Esta proteína bloqueia a função lítica do complexo SC5b-9, pois interage com este complexo no local de interação deste com a membrana. A interação da vitronectina ocorre na etapa de formação do complexo C5b-7. Entretanto, esta proteína não é capaz de interferir na interação deste complexo com as moléculas C8 e C9. A atividade lítica do complexo solúvel SC5b-9 pode ser restaurada pela dissociação reversível da vitronectina (Bhakdi et al., 1988; Tegla et al.,2011). 


\subsection{Moléculas que compõem o MAC}

\subsubsection{Proteína C5}

A proteína C5 é sintetizada como uma pró-molécula de cadeia simples de 1676 aminoácidos incluindo um peptídeo sinal de 18 aminoácidos, sendo encontrada no soro em concentrações que variam entre 0,07 e $0,16 \mathrm{mg} / \mathrm{mL}$ em adultos saudáveis (Pfarr et al., 2005). As principais células produtoras de C5 são os hepatócitos, contudo macrófagos alveolares e células epiteliais também secretam esta proteína (Tegla et al., 2011).

O gene C5 humano está localizado no cromossomo 9 e possui 41 éxons. C5 é uma proteína de $190 \mathrm{kDa}$ e possui duas cadeias: $\alpha(115 \mathrm{kDa})$ e $\beta(75 \mathrm{kDa})$, as quais são unidas por pontes de dissulfeto. Esta proteína é estruturalmente homóloga à proteína C3 sendo organizada em 13 domínios (Bubeck, 2014).

A molécula C5 é um componente que participa das três vias de ativação do sistema complemento. O processo inicia-se pela clivagem proteolítica da molécula de C5 em dois componentes (C5a e C5b) pelas C5 convertases da Via Alternativa (C3bBbC3b) ou das Vias Clássicas e das Lectinas $(\mathrm{C} 4 \mathrm{bC} 2 \mathrm{aC} 3 \mathrm{~b})$. O fragmento C5a é a mais potente anafilotoxina proinflamatória, além de ser um fator quimiotático para neutrófilos, enquanto C5b se associa sequencialmente aos componentes C6, C7, C8 e nC9 (Figura 5B), formando assim o complexo de ataque à membrana (MAC), que promove a lise celular (Bubeck, 2014; Tegla 2011). 


\subsubsection{Proteína C6}

A proteína C6 é sintetizada como um precursor de cadeia polipeptídica única de 934 aminoácidos incluindo um peptídeo sinal de 21 aminoácidos, sendo a mais longa proteína do MAC com massa molecular aproximada de $100 \mathrm{kDa}$. As principais células produtoras de C6 são os hepatócitos e os macrófagos, sendo a concentração plasmática da proteína $45 \mu \mathrm{g} / \mathrm{ml}$. C6 é uma proteína glicosilada e possui dez domínios: três Thrombospondin type 1 repeats (TS), um Lipoprotein receptor class A repeat (LR), um Membrane attack complex/perforina (MACPF), um Epidermal growth factor like repeat (EGF), dois Complement Control Protein repeats (CCP) e dois Factor I/membrane attack complex 6/7 modules (FIM) (Figura 5A) apresentando uma conformação parcialmente estendida (Aleshin et al., 2012).

O gene C6 humano está localizado no cromossomo 5 e contém 18 éxons (Hobart et al, 1993). A proteína C6 conecta os demais componentes da Via Terminal ao C5b, o último produto de clivagem da cascata do Complemento. A associação entre C5b e C6 facilita a ligação de C7 a estas moléculas alterando a conformação do complexo. Entretanto, na ausência de C7, C5b6 tem maior meia-vida (DiScipio, Hugli, 1989).

Pacientes deficientes de C6 apresentam um aumento de susceptibilidade a infecções sistêmicas por Neisseria gonorrhoeae e também a infecções recorrentes tais como a meningite meningocócica (Orren et al., 2011). 

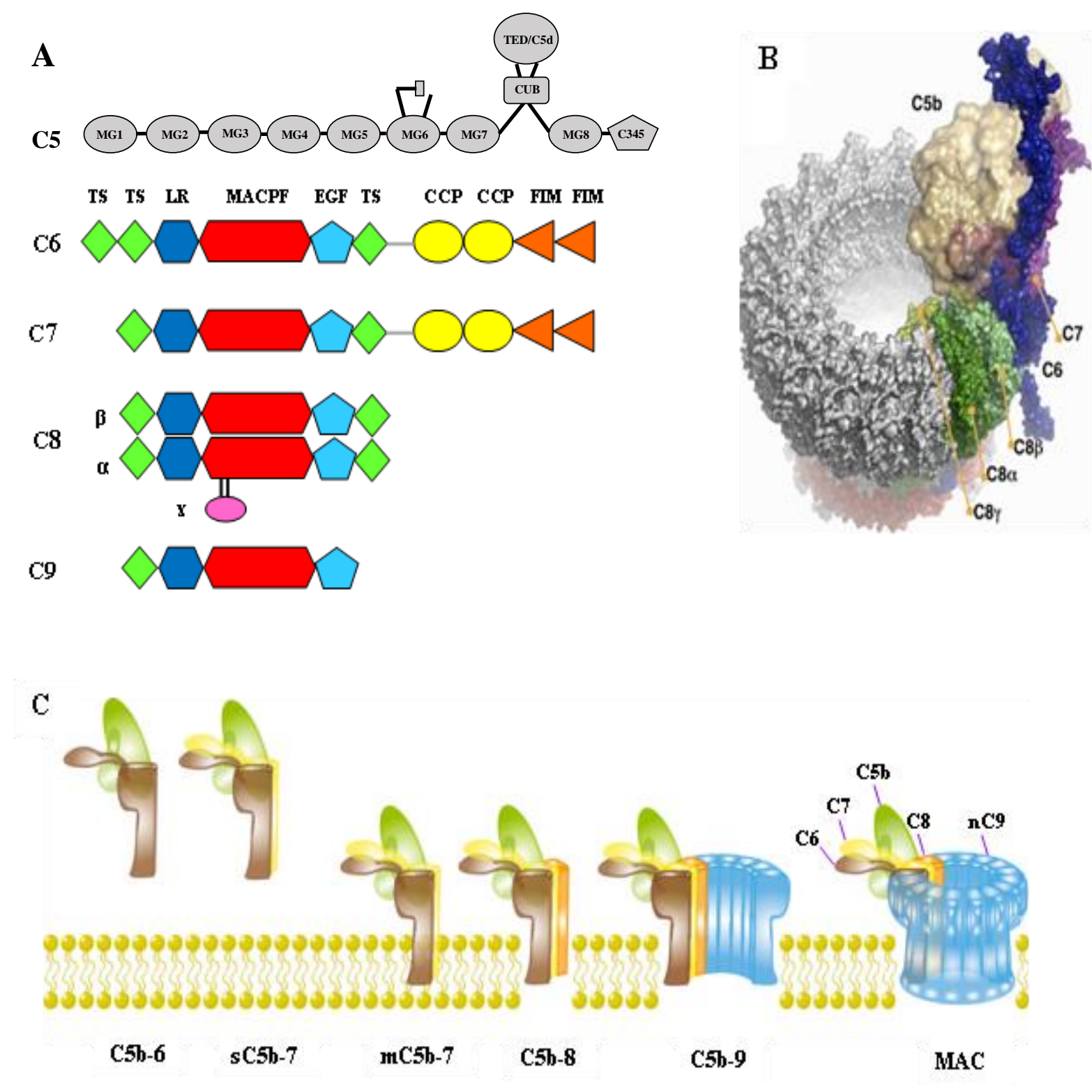

Figura 4 - Representação esquemática das proteínas que compõe o MAC e formação do complexo. (A) Comparação das proteínas C6 ao C9 e seus respectivos domínios: Thrombospondin type 1 repeats (TS), Lipoprotein receptor class A repeat (LR), Membrane attack complex/perforin (MACPF), Epidermal growth factor like repeat (EGF), Complement control protein repeats (CCP) e Factor I/membrane attack complex 6/7 modules (FIM). (B) Modelo atômico para o complexo C5b-8. (C) Representação esquemática da formação do Complexo de Ataque à Membrana (Aleshin et al., 2012; Berends et al., 2014; Bubeck, 2014). 


\subsubsection{Proteína C7}

A molécula C7 é uma glicoproteína de cadeia única de $95 \mathrm{kDa}$ composta por 843 aminoácidos incluindo um peptídeo sinal de 22 aminoácidos (Barroso et al., 2004). Esta proteína plasmática encontra-se na concentração de $90 \mu \mathrm{g} / \mathrm{ml}$. Dados da literatura sugerem que C7 possua uma arquitetura similar à de C6. Quando o complexo C5b-6 liga-se avidamente à molécula C7, gera o complexo C5b-7 capaz de se associar e penetrar minimamente na bicamada lipídica. No entanto, este completo não induz lise celular (Aleshin et al., 2012; Bubeck, 2014 Tegla et al., 2011).

O gene $C 7$ humano está localizado no cromossomo 5 sendo codificado por 18 éxons (Barroso et al., 2006). Mutações no gene $C 7$ podem causar deficiência desta proteína causando perda da função lítica do Complemento, promovendo aumento da susceptibilidade a infecções recorrentes por Neisseria meningitidis (Barroso et al., 2006; DiScipio et al., 1988).

C7 é uma das cinco proteínas que compõem o MAC desempenhando um papel importante na transição hidrofílico-anfifílica, pois confere ao complexo C5b-7 a capacidade de se ligar diretamente à membrana da célula alvo (Figura 5C). Este complexo ligado à membrana permite que $\mathrm{C} 8$ e C9 se associem sequencialmente possibilitando assim a formação do poro transmembranar (DiScipio et al., 1988). 


\subsubsection{Proteína C8}

A molécula C8 encontra-se na circulação como uma proteína oligomérica de $151 \mathrm{kDa}$, composta por 3 polipeptídeos: cadeia $\alpha(64 \mathrm{kDa})$, cadeia $\beta(64 \mathrm{kDa})$ e cadeia $\mathrm{\gamma}(22 \mathrm{kDa})$. As principais células produtoras de C8 são hepatócitos, monócitos, macrófagos, fibroblastos, astrócitos e células endoteliais. Sua concentração plasmática varia entre 55 e $80 \mu \mathrm{g} / \mathrm{ml}$ (Schreck et al., 2000).

C $8 \alpha$ e C8 $\beta$ possuem elevada homologia com as demais proteínas que compõe o MAC, possuindo diversos domínios em comum, tais como o Membrane attack complex/perforina (MACPF) (Figura 5A) (Hadders et al., 2007). Contudo, a inserção do poro na membrana celular tem sido atribuída somente ao domínio MACPF de C8 $\alpha$. Já o domínio MACPF de C8 $\beta$ é capaz de interagir com o complexo C5b-7 (Figura 5B). A subunidade C8y é um membro da família da lipocalina que se liga e transporta pequenos ligantes hidrofóbicos e está associado ao $\mathrm{C} 8 \alpha$ por ligação dissulfeto. Dados da literatura indicam que $\mathrm{C} 8 \gamma$ pode não ser imprescindível para a função de lise, mas ele pode aumentar a atividade do MAC. Isto é possível devido a indução de alteração conformacional de $\mathrm{C} 8 \alpha$ que aumenta a sua afinidade pelo complexo C5b-7 e/ou C9, ou pode facilitar a formação de mais MAC liticamente ativo. (Schreck et al., 2000).

Cada subunidade da molécula de C8 é codificada por diferentes genes. Os genes $C 8 \alpha \mathrm{e}$ $C 8 \beta$ estão localizados no cromossomo $1 \mathrm{p} 32$, enquanto o gene $C 8 \gamma$ está situado no cromossomo 9q. O gene $C 8 \alpha$ se estende por $70 \mathrm{~kb}$ e possui 11 éxons. A proteína $\mathrm{C} 8 \alpha$ possui 553 resíduos de aminoácidos, sendo composta por um domínio que interage com a subunidade $\beta$ e compreende um sítio de ligação para C9 (Kojima et al., 1998). O gene $C 8 \beta$ abrange cerca de $40 \mathrm{~kb}$ e contém 12 éxons. A subunidade C $8 \beta$ possui um domínio que interage com a membrana da célula alvo e um domínio que medeia exclusivamente o reconhecimento e ligação de $\mathrm{C} 8$ ao complexo C5b-7. O gene C8y se estende por aproximadamente $1,8 \mathrm{~kb}$ e possui 7 éxons. A proteína $\mathrm{C} 8 \mathrm{y}$ é composta por 182 resíduos de aminoácidos e se conecta à $\mathrm{C} 8 \alpha$ por pontes dissulfeto (Bubeck et al., 2011; Kojima et al., 1998).

Dois tipos de deficiências da proteína C8 foram relatados em pacientes: tipo I, em que C8 $\alpha$ e C8y são ambos deficientes, e tipo II, em que somente C8 $\beta$ é deficiente. Os dois tipos são clinicamente indistinguíveis. Deficiências de $\mathrm{C} 8 \alpha-\gamma$ têm sido relatadas predominantemente em negros, hispânicos e japoneses, sendo estas frequentemente 
associadas a infecções recorrentes por Neisseria meningitidis. Já as deficiências de C8ß têm sido descritas principalmente em caucasianos (Kojima et al., 1998; Ross, Densen, 1984). 


\subsubsection{Proteína C9}

O componente C9 é uma proteína globular de cadeia única de $71 \mathrm{kDa}$ com 558 aminoácidos, incluindo um peptídeo sinal de 20 aminoácidos. Esta proteína encontra-se no soro na concentração de $60 \mu \mathrm{g} / \mathrm{ml}$. As moléculas de C9 são bastante expressas por hepatócitos, mas podem ser produzidas também por monócitos, fibroblastos e células da glia. O gene $C 9$ estende-se por aproximadamente $100 \mathrm{~kb}$ sendo composto por 11 éxons e esta localizado no cromossomo 5p13 (DiScipio, Hugly, 1985; Tegla et al., 2011).

A molécula C9 apresenta $27 \%$ e $34 \%$ de homologia com as proteínas C6 e C8, respectivamente. Múltiplas cópias de C9 (12 a 18) são associadas ao complexo C5b-8 para formar poros capazes de promover a lise celular (Tegla et al., 2011). A porção N-terminal de C9 é predominantemente hidrofílica, enquanto a parte C-terminal é em sua maior parte hidrofóbica. A organização anfipática da estrutura primária está relacionada com a capacidade das moléculas C9 polimerizadas penetrarem na bicamada lipídica e promoverem a formação de canais transmembrana com função lítica (DiScipio et al., 1984).

Embora a molécula de C9 seja uma glicoproteína solúvel, é possível induzir a sua polimerização espontaneamente após incubação prolongada a $37^{\circ} \mathrm{C}$ sob condições adequadas, como por exemplo na presença de íons zinco $\left(\mathrm{Zn}^{2+}\right)$. O polímero de C9 é considerado uma proteína de membrana integral por ser uma estrutura transmembranar formadora de poro (Figura 5C) (DiScipio et al., 1984).

A deficiência de C9 é herdada como uma característica autossômica recessiva resultando na incapacidade de formação do MAC. Apesar de ser considerada rara em países ocidentais, a deficiência de C9 é a mais comum entre as deficiências do Complemento em países orientais como o Japão e Coréia. Esta imunodeficiência promove um aumento da susceptibilidade a infecções por Neisseria, demonstrando um elevado risco de desenvolvimento de meningite meningocócica (Kang et al., 2005). 


\subsection{Reguladores da Formação do MAC}

Para evitar uma ativação inadequada sobre células normais do hospedeiro e limitar o consumo das proteínas do Complemento, a cascata de ativação e a estabilidade das moléculas ativadas são rigorosamente reguladas por diversas proteínas plasmáticas e outras ligadas à membrana celular (Zipfel, Skerka, 2009).

A Clusterina é uma glicoproteína de $70 \mathrm{kDa}$ que pode ser encontrada no plasma em associação com lipoproteínas. Este regulador do complemento liga-se ao complexo C5b-7, impedindo a sua interação com a membrana, e inibindo a formação de C5b-8 e C5b-9. A Clusterina está associada ao complexo SC5b-9 inativo formado em conjunto com a Vitronectina (Tegla et al., 2011).

A S-proteína ou Vitronectina é uma glicoproteína de $80 \mathrm{kDa}$ que foi primeiramente descrita como sendo um componente do complexo C5b-9 no soro. Esta proteína interage com o complexo C5b-7 solúvel, formando SC5b-7 e incapacitando este complexo de se ligar à membrana. SC5b-7 pode se associar a uma molécula de C8 ou a três de C9 para gerar SC5b-8 e SC5b-9, respectivamente. Todos esses complexos são denominados inativos e são incapazes de se ligar à membrana. A Vitronectina também é capaz de inibir a polimerização de C9 e a formação do canal pela perforina, limitando desta maneira a geração do poro pelo Complemento e por linfócitos citotóxicos (Tegla et al., 2011).

O CD59 é o principal inibidor do MAC, sendo muito expresso em células sanguíneas, endoteliais e em diversos tipos de células não vasculares. Além de ser encontrado como proteína de membrana, o CD59 também está presente na sua forma solúvel no sangue, urina e outros fluidos corporais. Este regulador atua sobre os complexos C5b-8 e C5b-9 inibindo a incorporação de moléculas de C9 adicionais durante a formação do poro. Deste modo, essa proteína é capaz de inibir a formação do MAC evitando a lise de células do próprio hospedeiro (Farkas et al., 2002; Miwa, Song, 2001; Tegla et al., 2011).

Além de reguladores do hospedeiro, certos patógenos possuem a capacidade de controlar e escapar do Sistema Complemento, possibilitando o estabelecimento da infecção (Zipfel et al., 2007). Estes mecanismos de evasão do complemento serão apresentados a seguir. 


\subsection{Mecanismos de evasão ao Sistema Complemento}

O Sistema Complemento é um importante componente da imunidade inata e adquirida, e desempenha um papel fundamental para o reconhecimento e eliminação dos patógenos, que por sua vez, desenvolveram estratégias de evasão, possibilitando o estabelecimento da infecção (Lambris et al., 2008; Rooijakkers, van Strijp, 2007; Zipfel et al., 2007).

Borrelia recurrentis e $B$. duttonii são patógenos causadores de severa doença séptica, interagem com os reguladores FH e C4BP contribuindo para a resistência ao soro e evasão ao Complemento (Meri et al., 2006). Staphylococcus aureus pode causar uma variedade de doenças agudas e crônicas. A proteína Extracellular fibrinogen binding protein (EfB) secretada por $S$. aureus se liga ao componente C3 inibindo a ativação das Vias Clássica e Alternativa do Complemento (Lee et al., 2004).

Estudos anteriores demonstraram que leptospiras saprófitas, quando incubadas em soro humano normal, são eliminadas rapidamente, revelando notadamente a participação do Sistema Complemento. Ao contrário, estirpes patogênicas são resistentes ao soro sendo, portanto, capazes de sobreviver à ação do Complemento, o que possibilita a sua disseminação no organismo e o estabelecimento da infecção (Barbosa et al., 2009; Meri et al., 2005).

Um dos mecanismos de escape das leptospiras patogênicas é a expressão de proteínas de membrana que interagem com uma variedade de componentes da matriz extracelular e adquirem reguladores negativos do Complemento tais como o FH e o C4BP. O FH inibe a ativação da Via Alternativa ao se associar à molécula C3b depositada na superfície do patógeno, e atuar como cofator para a ação proteolítica do Fator I (FI), capaz de clivar C3b e inativá-lo (Castiblanco-Valencia et al., 2012). Estirpes patogênicas também são capazes de interagir com C4BP, que ao se ligar à membrana da bactéria, retém atividade de cofator de FI, enzima responsável pela clivagem de C4b, inibindo as Vias Clássica e das Lectinas (Barbosa et al., 2009). Proteínas de membrana externa das leptospiras tais como o fator de elongação Tu (Wolff et al., 2013), que se liga ao FH, a proteína LcpA que se liga ao C4BP (Barbosa et al., 2010) e as proteínas LigA e LigB que se ligam a ambos os reguladores foram identificadas como ligantes destes reguladores. A LcpA ainda é capaz de interagir com o FH e a Vitronectina, interferindo em todas as etapas do Complemento (da Silva et al., 2015). As leptospiras saprófitas são susceptíveis à ação do Complemento e pouco se ligam a esses reguladores negativos (Castiblanco-Valencia et al., 2012).

As proteínas LenA e LenB se ligam intensamente ao FH e factor H-related protein 1 (FHR-1), sugerindo ter um papel importante na colonização da bactéria no organismo e 
proteção contra a resposta imune do hospedeiro (Barbosa et al., 2006; Stevenson et al., 2007; Verma et al., 2006). As proteínas Lsa23, Lsa26 e Lsa36 interagem com componentes da matriz extracelular tais como laminina e plasminogênio. Lsa23 se liga ao FH e C4BP promovendo a inibição do Complemento e estabelecimento da infecção (Siqueira et al., 2013).

Leptospiras patogênicas possuem também a capacidade de adquirir moléculas precursoras de proteases do hospedeiro, como o plasminogênio. Uma vez ligado à superfície da leptospira, o plasminogênio pode ser convertido em plasmina na presença de ativadores como o urokinase-type plasminogen activator (uPA). A plasmina é uma protease que apresenta uma ampla especificidade, clivando moléculas da matriz extracelular como o fibrinogênio, e proteínas do Complemento como o fragmento C3b e C5 (CastiblancoValencia et al., 2016). A plasmina também degrada macromoléculas tais como fibronectina, laminina, elastina e proteoglicanos (Vieira et al., 2009; Wolff et al., 2013).

Diversos microrganismos patogênicos tais como bactérias, fungos, parasitas e vírus, secretam proteases capazes de clivar diferentes componentes do Complemento, possuindo desta forma, uma estratégia de evasão ao sistema imune do hospedeiro. As principais classes de proteases envolvidas na clivagem de moléculas do Complemento são as cisteíno, aspartil, serino e metalo proteases (Mandujano-González et al., 2016; Potempa et al., 2009).

A bactéria Streptococcus pyogenes secreta a cisteínoprotease streptococcal pyrogenicexotoxin $B(\mathrm{SpeB})$ que apresenta atividade proteolítica sobre as proteínas do Complemento $\mathrm{C} 3 \mathrm{~b}$ e Properdina, que é um regulador positivo da Via Alternativa. Além disso, a SpeB possui também a capacidade de degradar moléculas que compõem o MAC (HondaOgawa et al., 2013).

A importância das cisteíno proteases está relacionada à periodontite, uma doença caracterizada pela inflamação crônica nas estruturas subgengivais dos dentes causada por um conjunto de bactérias incluindo Porphyromonas gingivalis e Prevotella intermedia que secretam as proteases gingipaína e interpaína A, respectivamente. O efeito protetor da protease interpaína A contra a atividade bactericida do soro foi atribuída à sua capacidade de degradar a cadeia $\alpha$ de C3, inibindo as três vias de ativação do Complemento. Além disso, gingipaína e interpaína A atuam sinergicamente na degradação da molécula C3b do Complemento, favorecendo a sobrevida das bactérias e o estabelecimento da infecção (Potempa et al., 2009).

Dentre as aspartil proteases que degradam proteínas do Complemento, há proteases de membrana como a outer membrane protein E (PgtE) de Salmonella enterica e também secretadas como as secreted aspartic proteinases (Saps) de Candida albicans. A protease 
PgtE degrada C3, C3b, C4b e C5 e sua expressão aumenta a resistência da bactéria ao soro humano, contribuindo para a disseminação da Salmonella enterica durante a infecção sistêmica (Ramu et al., 2007). Recentemente, Riva e colaboradores mostraram que PgtE também é capaz de degradar FB e FH visando tanto a ativação como a inibição do Complemento, uma vez que a clivagem de FH pode anular a atividade regulatória do Complemento levando a um aumento da formação de $\mathrm{C} 3 \mathrm{~b}$, ao passo que a clivagem de $\mathrm{FB}$ pode levar à redução da quantidade de $\mathrm{C} 3$ convertases ativas diminuindo a geração de $\mathrm{C} 3 \mathrm{~b}$ (Riva et al., 2015).

Proteases aspárticas secretadas pela bactéria Candida albicans denominadas Saps representam uma família de dez proteínas com múltiplas funções na patogenicidade do microrganismo tais como adesão, invasão e danos às células do hospedeiro. As clivagens de C3b, C4b, e C5 pelas Saps 1, 2, e 3 resultam em redução na fagocitose da levedura, sendo observada uma diminuição da inflamação, a qual pode estar relacionada aos baixos níveis da anafilotoxina C5a detectados na presença das proteases (Gropp et al., 2009).

Enzimas proteolíticas da classe das serino proteases são produzidas por fungos (Aspergillus fumigatus), parasitas (Schistosoma mansoni) e bactérias (Escherichia coli, Staphylococcus aureus e Neisseria meningitidis). A proteína central do Complemento C3 constitui um substrato comum às serino proteases produzidas por estes microrganismos. Além de C3, o sobrenadante de cultura de Aspergillus fumigatus também possui atividade proteolítica sobre $\mathrm{C} 4$ e C5. Esta atividade foi atribuída à serino protease alkaline serine protease 1 (Alp1), principal protease secretada pelo patógeno (Behnsen et al., 2010). Pacientes deficientes de moléculas do Complemento possuem uma elevada susceptibilidade a infecções invasivas por Neisseria. A atividade proteolítica da serine protease neisserial autotransporter $P$ (NalP) sobre a molécula de C3 também foi estudada. NalP é uma protease auto-transportadora que sofre auto-clivagem durante seu processo de secreção. Além da forma secretada, NalP também pode se apresentar em forma lipidada, a qual encontra-se ancorada na membrana externa da bactéria (Roussel-Jazédé et al., 2013).

As metalo proteases que degradam proteínas do Complemento foram descritas em bactérias como Staphylococcus aureus, Pseudomonas aeruginosa, Enterococcus faecalis e Tannerella forsythia. A bactéria Gram-negativa P. aeruginosa secreta toxinas e fatores de virulência tais como a protease alcalina A (AprA) e a elastase que clivam uma variedade de proteínas e componentes do Complemento. AprA é uma metalo protease que cliva $\mathrm{C} 3 \mathrm{~b}$ e impede a sua deposição na superfície da bactéria, dificultando importantes funções do 
Complemento como a fagocitose por neutrófilos humanos, além de clivar a molécula C2 bloqueando as Vias Clássicas e das Lectinas (Laarman et al., 2012).

Staphylococcus aureus secreta diversas proteases que podem fornecer à bactéria resistência ao Sistema Complemento de forma semelhante àquela observada com os agentes patogênicos periodontais tais como Porphyromonas gingivalis, Prevotella intermedia $e$ Tannerella forsythia. As principais proteases secretadas por S. aureus incluem duas cisteíno proteases, staphopain $A(\mathrm{Scp} A)$ e staphopain $B(\mathrm{SspB})$ que degradam elastina, colágeno e fibrinogênio levando à destruição do tecido, uma serino protease (V8) que degrada imunoglobulinas humanas, e uma metalo protease, a aureolisina (Aur), que cliva a molécula $\mathrm{C} 3 \mathrm{em} \mathrm{C} 3 \mathrm{~b}$ sendo rapidamente degradado pelo FI e FH presentes no soro, ocasionando assim uma redução na opsonização por C3b e atenuação da fagocitose da bactéria por neutrófilos (Jusko et al., 2014; Potempa, Potempa, 2012).

A metalo protease gelatinase $\mathrm{E}$ (GelE) de E. faecalis tem a capacidade de hidrolisar o fibrinogênio e o colágeno. GelE além de exercer atividade proteolítica sobre a cadeia $\alpha$ de $\mathrm{C} 3$ na presença de FI e FH, também é capaz de degradar os fragmentos C3b, C3a e iC3b, reduzindo a fagocitose do patógeno por leucócitos polimorfonucleares humanos. GelE inativa a molécula C3 que resulta na inibição das três vias de ativação do Sistema Complemento promovendo um aumento da sobrevivência de E. faecalis no do hospedeiro (Potempa et al., 2009).

Em um estudo anterior realizado por nosso grupo, observamos que várias espécies de leptospiras patogênicas foram capazes de secretar proteases que clivam proteínas do Complemento, enquanto as saprófitas não apresentaram atividade proteolítica significativa sobre tais moléculas (Figura 6). As proteases secretadas por leptospiras patogênicas apresentaram a capacidade de degradar a molécula central C3, assim como seus fragmentos C3b e iC3b, e também proteínas da Via Alternativa (FB), Clássica e das Lectinas (C4b e C2) constituindo um mecanismo de evasão ao Sistema Complemento (Fraga et al., 2014b).

Para identificar as classes de proteases envolvidas na clivagem das moléculas do Complemento, nosso grupo realizou ensaios de inibição, nos quais os sobrenadantes das leptospiras patogênicas foram tratados com inibidores de proteases. Os ensaios indicaram que somente a classe das metalo proteases foi capaz de inibir a atividade proteolítica do Complemento. Identificamos também uma das proteases responsáveis pelas clivagens, a Termolisina, que é uma metalo protease capaz de clivar a molécula C3. De forma interessante, verificamos que a Termolisina é encontrada unicamente em espécies patogênicas de leptospira, não sendo expressa pelas bactérias saprófitas (Fraga et al., 2014b). 
A habilidade de degradar moléculas do Complemento pode contribuir para os processos de invasão e disseminação desse patógeno no hospedeiro. O componente C5 também foi clivado por proteases de leptospiras patogênicas, porém apenas quando esta proteína purificada foi empregada como substrato, uma vez que tais proteases não foram capazes de clivar C5 no soro humano normal (Fraga et al., 2014b). Neste trabalho expandimos a análise da atividade proteolítica das proteases secretadas por leptospiras patogênicas sobre os demais componentes da Via Terminal: C6, C7, C8 e C9, sendo este o objetivo de estudo deste trabalho.

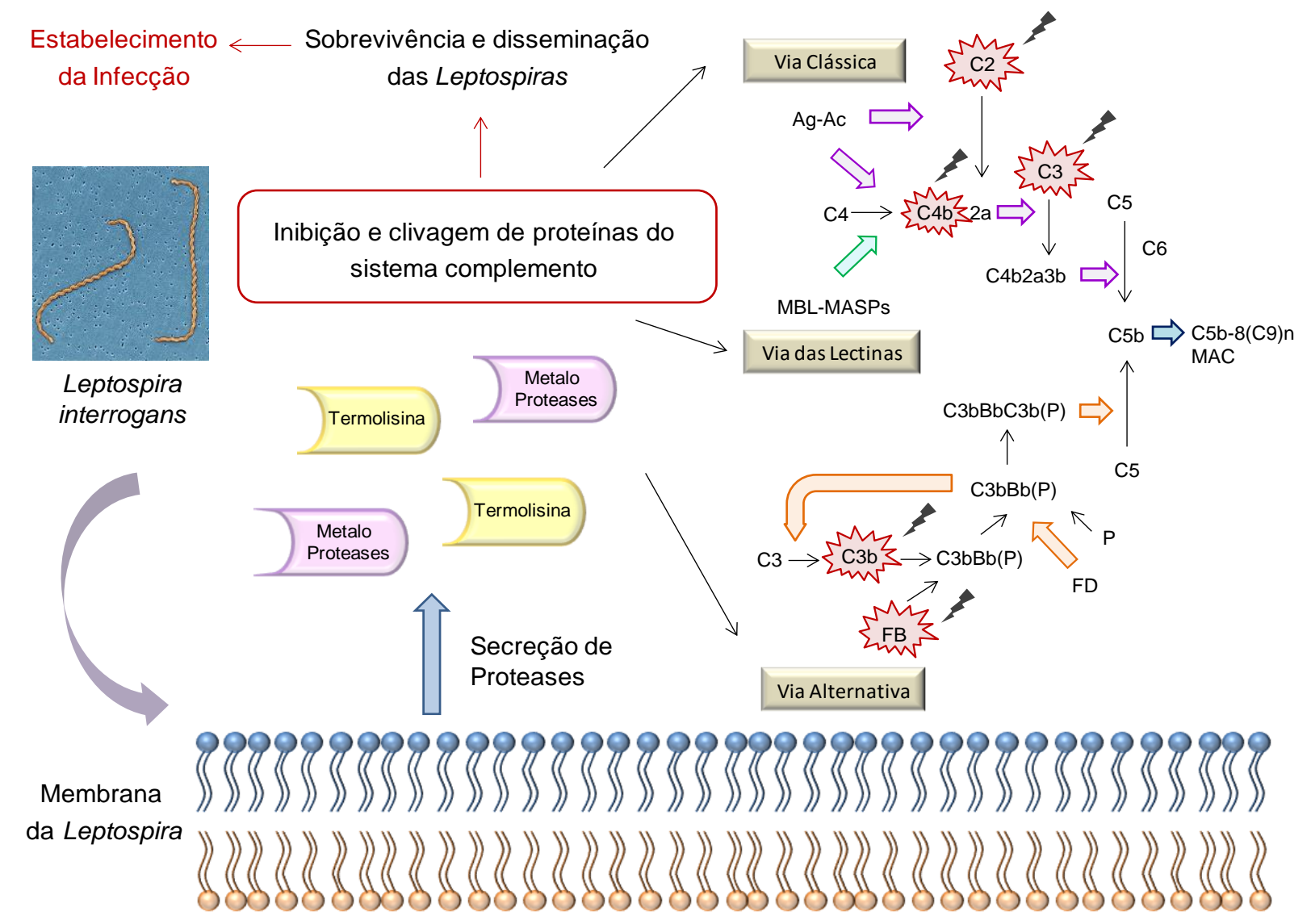

Figura 5 - A secreção de proteases pelas leptospiras patogênicas constitui um mecanismo de evasão imune ao Sistema Complemento. Leptospira interrogans secreta metalo proteases capazes de clivar proteínas das três vias do Sistema Complemento: C3, C3b, iC3b, Fator B, C2 e C4b. Dentre as proteases secretadas encontra-se a Termolisina, uma metalo protease expressa exclusivamente por estirpes patogênicas que degrada C3 (Fraga et al., 2014b). 
2 OBJETIVO 


\subsection{Objetivo Geral}

O objetivo deste estudo é investigar a atividade proteolítica dos sobrenadantes de leptospiras sobre os componentes C6, C7, C8 e C9 do MAC humano.

\subsection{Objetivos específicos}

1. Avaliação da atividade proteolítica dos sobrenadantes de cultura de leptospiras patogênicas e não patogênicas sobre as proteínas purificadas de C6, C7, C8 e C9;

2. Análise da seletividade das proteases secretadas pelas leptospiras, utilizando concentrações reduzidas dos sobrenadantes nas reações proteolíticas com as proteínas purificadas C6-C9;

3. Análise da atividade proteolítica dos sobrenadantes das leptospiras sobre as proteínas C6-C9 purificadas em diferentes tempos de reação;

4. Determinação da natureza química das proteases de leptospira que atuam nas clivagens das proteínas purificadas C6-C9 do MAC, empregando diferentes classes de inibidores de proteases;

5. Avaliação da atividade proteolítica dos sobrenadantes de cultura de leptospiras, utilizando soro humano normal como fonte de C6-C9;

6. Análise da atividade proteolítica dos sobrenadantes das leptospiras sobre o complexo solúvel SC5b-9;

7. Análise da atividade proteolítica da Termolisina recombinante de Leptospira interrogans sobre os componentes C6-C9 do MAC e o complexo solúvel SC5b-9 purificados;

8. Análise da interação da Termolisina com os componentes C6-C9;

9. Avaliação da capacidade da Termolisina em inibir a formação do C6-C9. 
3 MATERIAIS E MÉTODOS 


\subsection{Espécies de leptospiras e condições de cultivo}

Neste estudo, foram utilizados sorovares de leptospiras pertencentes a espécies patogênicas e saprófitas indicados na Figura 7. As culturas de leptospiras são regularmente mantidas no Laboratório de Zoonoses Bacterianas da Faculdade de Medicina Veterinária e Zootecnia da Universidade de São Paulo. As estirpes foram cedidas em colaboração com o Prof. Dr. Silvio de Arruda Vasconcellos.

1. L. interrogans sorovar Pomona estirpe Pomona

2. L. interrogans sorovar Kennewicki estirpe Fromm

3. L. interrogans sorovar Copenhageni estirpe $10 \mathrm{~A}$

4. L. kishneri sorovar Cynopteri estirpe 3522C

5. L. noguchi sorovar Panama estirpe CZ 214

6. L. biflexa sorovar Andamana estirpe $\mathrm{CH} 11$

7. L. biflexa sorovar Patoc estirpe Patoc I

Leptospiras patogênicas

Figura 6 - Espécies e Estirpes de leptospiras utilizadas neste estudo.

\subsection{Obtenção dos sobrenadantes de cultura de leptospiras}

As leptospiras foram cultivadas por sete dias em meio EMJH (BD Difco ${ }^{\mathrm{TM}}$, Franklin Lakes, New Jersey, Estados Unidos) modificado, a $29{ }^{\circ} \mathrm{C}$. Após esse período, as bactérias foram lavadas duas vezes com PBS $1 \mathrm{X}$ pH 7,4 e a concentração de bactérias foi determinada por contagem em câmara de Petroff-Hausser em microscópio óptico Olympus BX51 (Olympus, Shinjuku, Tóquio, Japão) empregando condensador de campo escuro Olympus UDCD (Olympus). Em seguida, as leptospiras foram ressuspendidas em PBS na concentração de $1,0 \times 10^{9}$ bactérias. Para permitir a secreção de proteases, as suspensões bacterianas foram incubadas a $37{ }^{\circ} \mathrm{C}$ por $4 \mathrm{~h}$. Após centrifugação, os sobrenadantes foram coletados, filtrados em membrana de $0,22 \mu \mathrm{m}$ e estocados a $-80^{\circ} \mathrm{C}$, sendo utilizados nos ensaios funcionais.

EMJH modificado: meio EMJH com 10\% de soro de coelho (Bio Nutrientes, Barueri, SP, Brasil) enriquecido de L-asparagina (0,015\% - Inlab, Diadema, São Paulo, Brasil), piruvato de sódio (0,001\% - Inlab), cloreto de magnésio (0,001\% - Merck, Whitehouse Station, New 
Jersey, Estados Unidos), cloreto de cálcio (0,001\% - Sigma, Saint Louis, Missouri, Estados Unidos), peptona $\left(0,03 \%\right.$ - BD Difco $\left.{ }^{\mathrm{TM}}\right)$ e extrato de carne $\left(0,02 \%\right.$ - BD Difco $\left.{ }^{\mathrm{TM}}\right)$.

\subsection{Proteínas do complemento e anticorpos}

As proteínas do Sistema Complemento humano C6, C7, C8, C9 e o complexo SC5b-9 purificados, bem como os anticorpos policlonais específicos contra essas proteínas foram obtidos comercialmente da empresa Complement Technology (Texas, TX, Estados Unidos). Os anticorpos primários anti-C6, -C7, -C8 e -C9 humanos feitos em cabra foram utilizados na diluição 1:2000 e o anticorpo secundário anti-cabra conjugado com peroxidase, na diluição 1:5000.

\subsection{Análise da atividade proteolítica de diferentes sobrenadantes de leptospiras sobre as proteínas C6-C9 do MAC}

Este ensaio foi realizado com a finalidade de avaliar a atividade proteolítica de diferentes sobrenadantes de leptospiras patogênicas e saprófitas sobre as moléculas que compõem o MAC.

Os sobrenadantes das diferentes estirpes de leptospira (1,5 $\mu \mathrm{g}$ de proteína total) foram incubados por $1 \mathrm{~h}$ com as proteínas purificadas C6, C7, C8 ou C9 $\left(0,25 \mu \mathrm{g}\right.$ cada) a $37{ }^{\circ} \mathrm{C}$. As reações foram submetidas à SDS-PAGE (Laemmli, 1970) 12\% e 15\% e as clivagens foram analisadas por Western Blot com anticorpos policlonais específicos contra as proteínas do complemento.

\subsection{Análise das clivagens das proteínas C6-C9 por Western Blot}

Para análise das clivagens das proteínas do MAC, as reações proteolíticas foram submetidas à SDS-PAGE. Foram utilizados géis de $1 \mathrm{~mm}$ de espessura na concentração de 5\% no gel de empilhamento e 10 a $15 \%$ no gel de separação. Uma vez adicionado o tampão de amostra $5 \mathrm{X}$, as amostras foram aquecidas a $96{ }^{\circ} \mathrm{C}$ por $3 \mathrm{~min}$. As corridas eletroforéticas foram efetuadas a $120 \mathrm{~V}$, em tampão de corrida à temperatura ambiente. Em seguida, as amostras foram transferidas do gel de poliacrilamida para uma membrana de nitrocelulose em sistema Mini-Trans-Blot Cell (Bio-Rad Laboratories, Califórnia, CA., Estados Unidos), por 1 h a $350 \mathrm{~mA}$. Após a transferência, a membrana foi incubada por $16 \mathrm{~h}$ a $4{ }^{\circ} \mathrm{C}$ com PBS-T 
contendo $10 \%$ de leite desnatado. Os anticorpos primários e secundários foram incubados sequencialmente à temperatura ambiente com agitação. A membrana foi lavada com PBS-T por 5 min entre cada uma das etapas anteriores. Finalmente, adicionamos solução de revelação à membrana, a qual foi então exposta a um filme fotográfico que foi sensibilizado pela quimioluminescência emitida.

Materiais utilizados nas técnicas de SDS-PAGE e Western blot:

- tampão de amostra 5X: Tris- $\mathrm{HCl} 50 \mathrm{mM}$ pH 6,8, azul de bromofenol 0,1\%, glicerol 10\%, $\beta$-mercaptoetanol $100 \mathrm{mM}$ e SDS 2\%

- tampão de corrida: Tris-HCl 25 mM, glicina 192 mM e SDS 0,1\%, pH 8,3

- tampão Tris- $\mathrm{HCl}$ pH 8,8: Tris- $\mathrm{HCl} 1,5 \mathrm{M}$ e SDS 0,1\%, $\mathrm{pH} 8,8$

- tampão Tris-HCl pH 6,8: Tris-HCl 0,5 M e SDS 0,1\%, pH 6,8

- acrilamida 30\%: acrilamida 29\% e N,N'-metilenobisacrilamida 1\% (Acrilamida mix)

- solução de persulfato de amônio: persulfato de amônio $10 \%$

- TEMED: N,N,N',N'-tetrametilenodiamina

- solução corante: ácido acético glacial 10\%, etanol 45\% e azul Coomassie R250 0,25\%

- solução descorante: ácido acético glacial 10\% e etanol $30 \%$

- PBS: cloreto de potássio 2,7 mM, cloreto de sódio $137 \mathrm{mM}$, fosfato dibásico de sódio $10 \mathrm{mM}$ e fosfato monobásico de potássio $1,7 \mathrm{mM}, \mathrm{pH} 7,4$

- PBS-T: PBS contendo Tween $200,05 \%$

- tampão de bloqueio: leite desnatado 10\% em PBS-T

- tampão de transferência: Tris-HCl 25 mM pH 8,3, glicina 192 mM, SDS 0,02\% e etanol $20 \%$

- solução de revelação: kitSuper Signal West Pico Chemiluminescent Substrate (Pierce, Ilinois, IL., Estados Unidos)

- filme fotográfico: Hyperfilm (GE Healthcare, Buckinghamshire, Reino Unido) 


\subsection{Análise da eficiência proteolítica dos sobrenadantes de cultura das leptospiras sobre os componentes do MAC}

Para confirmar a existência de atividade proteolítica nos sobrenadantes das leptospiras patogênicas e saprófitas, foram efetuados novos ensaios utilizando-se concentrações proporcionalmente duas, quatro e vinte vezes menores de proteína total, quando comparadas às reações iniciais $(0,07 \mu \mathrm{g}, 0,4 \mu \mathrm{g}$ e $0,9 \mu \mathrm{g}$, respectivamente). Assim, os sobrenadantes da patogênica L. interrogans sorovar Kennewicki estirpe Fromm e da saprófita L. biflexa sorovar Patoc estirpe Patoc I foram incubados com $5 \mu \mathrm{g}$ de cada proteína purificada do MAC por $1 \mathrm{~h}$ e 4 h a $37^{\circ} \mathrm{C}$.

As clivagens foram analisadas após separação das proteínas e fragmentos em gel de poliacrilamida e transferência para membrana de PVDF (Polyvinyl Difluoride), a qual foi corada com Coomassie Brilliant Blue R-250 0,1\% (Sigma-Aldrich) contendo 50\% de metanol e descoradas com ácido acético $10 \%$ contendo $50 \%$ de metanol.

\subsection{Avaliação da atividade enzimática das proteases secretadas por leptospiras em função do tempo de reação}

Com o objetivo de investigar se a atividade proteolítica observada nos sobrenadantes das leptospiras patogênicas seria tempo-dependente, foi realizado um ensaio de cinética no qual o tempo de incubação das reações foi aumentado gradativamente. Para tanto, os sobrenadantes das leptospiras $(1,5 \mu \mathrm{g}$ de proteína total) foram incubados com as proteínas purificadas do MAC C6, C7, C8 ou C9 $(0,25 \mu \mathrm{g})$ por diferentes tempos (5 min a $6 \mathrm{~h})$ a $37{ }^{\circ} \mathrm{C}$. Após este período, as clivagens foram analisadas por Western blot com anticorpos policlonais específicos contra cada proteína do MAC.

\subsection{Avaliação da atividade proteolítica dos sobrenadantes de cultura das leptospiras sobre o complexo solúvel SC5b-9 purificado}

A ativação do Complemento resulta na formação do MAC que promove a formação de poros causando lise celular. A montagem do complexo C5b-9 na ausência de uma membrana alvo, leva à associação da S-proteína gerando o complexo solúvel SC5b-9 (Hadders, 2007).

Com a finalidade de verificar se as proteases secretadas pelas leptospiras seriam capazes de clivar o complexo solúvel SC5b-9, os sobrenadantes das bactérias $(0,9 \mu \mathrm{g}$ de proteína total) foram incubados com $5 \mu \mathrm{g}$ do complexo purificado por $4 \mathrm{~h}$ a $37{ }^{\circ} \mathrm{C}$. 
As clivagens foram analisadas por SDS-PAGE 15\% em condições redutoras (tampão de amostra contendo $\beta$-mercaptoetanol $1,4 \%$ e aquecimento a $96{ }^{\circ} \mathrm{C}$ por $3 \mathrm{~min}$ ) e não redutoras (tampão de amostra sem $\beta$-mercaptoetanol e sem aquecimento). Após a separação no gel de poliacrilamida, as proteínas foram transferidas para membrana de PVDF. Para visualização das proteínas, a membrana foi corada com Coomassie Brilliant Blue R-250 0,1\% (Sigma-Aldrich) contendo 50\% de metanol e descoradas com ácido acético $10 \%$ contendo $50 \%$ de metanol.

\subsection{Análise da atividade proteolítica dos sobrenadantes de cultura de leptospiras utilizando soro humano normal (SHN) como fonte de proteínas do MAC}

Os ensaios proteolíticos foram efetuados inicialmente empregando-se as proteínas purificadas do MAC. Decidimos então utilizar o SHN como fonte das proteínas do Complemento, para verificar se as proteases secretadas pelas leptospiras seriam capazes de clivar estas proteínas em um contexto mais próximo ao fisiológico.

Os sobrenadantes de L. interrogans sorovar Kennewicki estirpe Fromm e L. biflexa sorovar Patoc estirpe Patoc I (1,5 $\mu \mathrm{g}$ em proteína total) foram incubados com $2 \mu 1$ de SHN (correspondente a 18-19 $\mu \mathrm{g}$ das proteínas do MAC), em diferentes tempos de incubação (4 h, $6 \mathrm{~h} \mathrm{e} 24 \mathrm{~h}$ ) a $37{ }^{\circ} \mathrm{C}$. As quantidades de proteínas foram calculadas considerando-se a concentração respectiva de cada molécula C6, C7, C8 e C9 no SHN. Os produtos de clivagem foram analisados por Western blot com anticorpos policlonais específicos contra as proteínas do Complemento.

\subsection{Determinação das classes de proteases envolvidas nas clivagens das proteínas do MAC}

O sobrenadante de cultura da leptospira patogênica L. interrogans sorovar Kennewicki estirpe Fromm $(1,5 \mu \mathrm{g}$ de proteína total) foi incubado, separadamente, com as diferentes classes de inibidores de proteases nas concentrações relacionadas na Tabela 1 (Fraga et al., 2014, Stevenson et al., 2015) por 30 min à temperatura ambiente. Após este período, foram adicionadas as proteínas do complemento C6, C7, C8 e C9 (0,1 $\mu$ g cada) e as reações foram incubadas por $2 \mathrm{~h}$ a $37^{\circ} \mathrm{C}$. Utilizamos como controle negativo reações contendo apenas os veículos nos quais foram diluídos os inibidores de proteases: etanol e etanol-água (1:1). A inibição da atividade enzimática foi analisada por Western blot com anticorpos específicos contra as proteínas C6-C9 do MAC. 
Tabela 1 - Inibidores de proteases utilizados nos ensaios de inibição.

\begin{tabular}{clc}
\hline Inibidor & Classes de proteases & Concentração utilizada \\
\hline PMSF & Serino proteases & $5 \mathrm{mM}$ \\
(fluoreto de fenilmetilsulfonilo) & Metalo proteases & $5 \mathrm{mM}$ \\
1,10 -fenantrolina & Cisteíno proteases & $28 \mu \mathrm{M}$ \\
E-64 & Aspartil proteases & $5 \mu \mathrm{M}$ \\
Pepstatina & Diversas endopeptidases & $3 \mu \mathrm{M}$ \\
\hline
\end{tabular}

\subsection{Análise da atividade proteolítica da Termolisina sobre os componentes do MAC e complexo solúvel SC5b-9}

Estudos anteriores realizados por nosso grupo demonstraram que a Termolisina, uma metalo protease expressa unicamente por estirpes patogênicas de leptospira, é uma das proteases responsáveis pelas clivagens das moléculas do complemento, sendo capaz de degradar a proteína C3 (Fraga et al., 2014b).

Para avaliar a atividade da Termolisina recombinante sobre as proteínas C6, C7, C8 e C9, e o complexo solúvel SC5b-9 $(0,25 \mu \mathrm{g})$ foram incubados com quantidades crescentes de Termolisina $(0,5-6 \mu \mathrm{g})$ durante $4 \mathrm{~h}$ a $37^{\circ} \mathrm{C}$. Os produtos de clivagem foram analisados por Western Blot utilizando anticorpos policlonais específicos contra cada uma das proteínas C6C9.

A Termolisina codificada pelo gene LIC13322 de Leptospira interrogans sorovar Copenhageni foi expressa em E. coli e purificada de acordo com Fraga et al. (2014b).

\subsection{Análise da interação da Termolisina com as proteínas do MAC por Western blot com sobreposição e ELISA}

No ensaio de Western blot com sobreposição, a Termolisina recombinante de Leptospira foi submetida à SDS-PAGE 12\% em condições não redutoras e transferida para membrana de nitrocelulose (Castiblanco-Valencia et al., 2012). Sítios de ligação inespecíficos foram bloqueados com $10 \%$ de leite desnatado em PBS-T por $16 \mathrm{~h} \mathrm{a} 4{ }^{\circ} \mathrm{C}$. Após três lavagens com PBS-T a membrana foi incubada por 90 min à temperatura ambiente com as proteínas do MAC purificadas (C6, C7, C8 ou C9) na concentração de $10 \mu \mathrm{g} / \mathrm{ml}$. Após cinco lavagens com 
PBS-T, as proteínas do MAC que se ligaram à Termolisina imobilizada na membrana foram detectadas utilizando anticorpos específicos (anti-C6, -C7, -C8 ou-C9), seguidos pela adição do anticorpo secundário anti-IgG de cabra, ambos na diluição 1:5000. Cada anticorpo adicionado foi incubado com a membrana por 60 min a $37{ }^{\circ} \mathrm{C}$, sendo efetuadas três lavagens com PBS-T ao final e entre estas incubações. A revelação foi efetuada por quimioluminescência empregando o kit SuperSignal West Pico Chemiluminescent (Thermo Scientific).

Para o ELISA, a Termolisina recombinante $(100 \mu \mathrm{l} ; 10 \mu \mathrm{g} / \mathrm{ml})$ foi imobilizada em placas de microdiluição (Costar 3590 High Binding, Corning Inc.) por incubação a $4{ }^{\circ} \mathrm{C}$ a 16 h. Os sítios não específicos de ligação foram bloqueados com BSA 3\% em PBS por 2 h a 37 ${ }^{\circ} \mathrm{C}$. Após este período, C6, C7, C8 ou C9 foram adicionados $(100 \mu \mathrm{l} ; 0-5 \mu \mathrm{g} / \mathrm{ml})$ e as proteínas incubadas por $1 \mathrm{~h}$ a $37^{\circ} \mathrm{C}$. Os componentes do MAC que se ligaram à Termolisina imobilizada foram detectados utilizando anticorpos específicos (anti-C6, -C7, -C8 ou -C9), seguidos pela adição do anticorpo secundário anti-IgG de cabra, ambos na diluição 1:5000. Cada anticorpo adicionado foi incubado por $1 \mathrm{~h}$ a $37{ }^{\circ} \mathrm{C}$, sendo efetuadas três lavagens com PBS-T ao final e entre cada uma das etapas acima descritas. A revelação foi efetuada com solução de revelação (OPD $0,04 \%, \mathrm{H}_{2} \mathrm{O}_{2}$ 0,015\% em tampão citrato-fosfato pH 5,0) e interrompida com a adição de $\mathrm{H}_{2} \mathrm{SO}_{4} 4 \mathrm{~N}$. A leitura da absorbância foi feita a $492 \mathrm{~nm}$ em leitor de microplacas (Labsystems Uniscience, Multiskan EX). A constante de dissociação (Kd) das interações foram calculadas por regressão não linear ajustando os dados à equação $\mathrm{Y}=\mathrm{Bmax}$ * E / $(\mathrm{Kd}+\mathrm{X})$ utilizando o GraphPad Prism 5.0 (GraphPad Software, Inc.).

Com a finalidade de avaliar se a interação das proteínas do MAC com a Termolisina é dependente de força iônica ou se é afetada pela adição de heparina, foram efetuados ensaios semelhantes aos descritos acima. A Termolisina recombinante $(100 \mu \mathrm{l} ; 10 \mu \mathrm{g} / \mathrm{ml})$ foi imobilizada em placas de microdiluição e, após bloqueio dos sítios inespecíficos, foi adicionado $1 \mu \mathrm{g}$ das proteínas do MAC (C6, C7, C8 ou C9) na presença de concentrações crescentes de $\mathrm{NaCl}$ (0 a $600 \mathrm{mM}$, diluídos em $10 \mathrm{mM}$ de $\mathrm{Na}_{2} \mathrm{HPO}_{4}$ e $1.8 \mathrm{mM} \mathrm{KH}_{2} \mathrm{PO}_{4}$ ) ou diferentes quantidades de heparina (0,05 a $1 \mu \mathrm{g}$, diluído em PBS). Os componentes do MAC que se ligaram à Termolisina imobilizada foram detectados utilizando anticorpos específicos (anti-C6, -C7, -C8 ou -C9), seguidos pela adição do anticorpo secundário anti-IgG de cabra. A revelação foi efetuada com OPD e interrompida com a adição de $\mathrm{H}_{2} \mathrm{SO}_{4} 4 \mathrm{~N}$, sendo a absorbância medida no comprimento de onda de $492 \mathrm{~nm}$. 


\subsection{Ensaio Hemolítico}

A atividade inibitória da Termolisina sobre o MAC foi analisada por meio de um ensaio hemolítico utilizando hemácias de carneiro (Hallström et al., 2009; da Silva et al., 2015). As hemácias foram lavadas e ressuspendidas para 2,0 x $10^{8}$ células $/ \mathrm{ml}$ em tampão Veronal (VBS; 1,8 mM barbital de sódio pH 7,5, $150 \mathrm{mM} \mathrm{NaCl}, 0,8 \mathrm{mM} \mathrm{MgCl} \mathrm{M}_{2}$ e 0,2 $\mathrm{mM}$ $\left.\mathrm{CaCl}_{2}\right)$ e foram pré-incubadas com C5b6 $(2 \mu \mathrm{g} / \mathrm{ml})$ por $1 \mathrm{~h}$ à temperatura ambiente sob agitação leve.

Em preparações separadas, a proteína C7 $(2 \mu \mathrm{g} / \mathrm{ml})$ foi adicionada a concentrações crescentes de Termolisina recombinante $\operatorname{LIC13322}(6,25$ a $50 \mu \mathrm{g} / \mathrm{ml})$ ou proteína recombinante de L. interrogans LIC10301 (50 $\mu \mathrm{g} / \mathrm{ml})$ utilizada como controle negativo, ambas pré-incubadas a $37{ }^{\circ} \mathrm{C}$ por $30 \mathrm{~min}$. Em seguida, as proteínas do complemento $\mathrm{C} 8(0,2$ $\mu \mathrm{g} / \mathrm{ml})$ e C9 $(2 \mu \mathrm{g} / \mathrm{ml})$ foram adicionados às misturas e incubadas por 15 min a $37^{\circ} \mathrm{C}$.

Suspensões de hemácias previamente revestidas com C5b6 foram adicionadas às misturas de (Termolisina-C7-C8-C9) ou (LIC10301-C7-C8-C9) e incubadas durante 30 min a $37{ }^{\circ} \mathrm{C}$. As hemácias foram então centrifugadas a $800 \times \mathrm{g}$ por $5 \mathrm{~min}$ e a quantidade de hemoglobina livre no sobrenadante, que representa as células lisadas, foi medida a $540 \mathrm{~nm}$. 
4 RESULTADOS 


\subsection{Avaliação da atividade proteolítica dos sobrenadantes de leptospiras sobre as proteínas C6-C9 purificadas}

A finalidade deste estudo foi avaliar a atividade dos sobrenadantes das culturas de leptospiras sobre as moléculas C6-C9 que compõem o MAC. Para isto, sete estirpes de leptospiras foram selecionadas: cinco patogênicas e duas saprófitas (Figura 7). Os sobrenadantes das diferentes estirpes de leptospiras foram incubados separadamente com as proteínas purificadas C6, C7, C8 e C9 e as clivagens foram analisadas por Western blot empregando anticorpos específicos contra cada proteína.

Neste ensaio, observamos que somente os sobrenadantes das culturas de leptospiras patogênicas apresentaram atividade proteolítica sobre as proteínas C6-C9 (Figura 8). O padrão de clivagem destas proteínas foi semelhante, quando utilizamos os sobrenadantes das culturas das cinco estirpes de leptospiras patogênicas, ao passo que as estirpes saprófitas não apresentaram atividade proteolítica significativa. 
C6

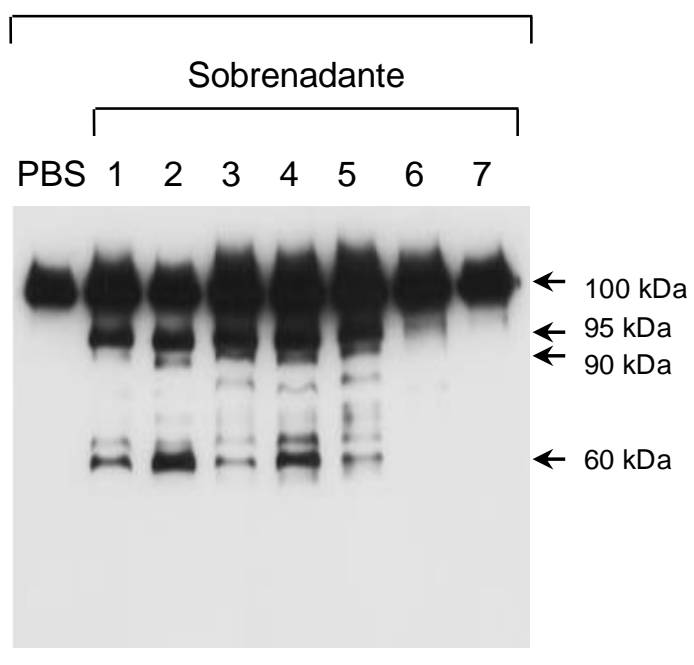

C8

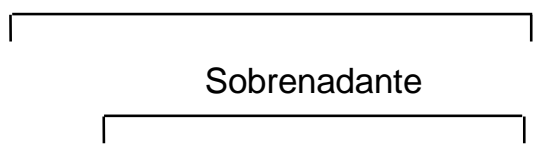

$\begin{array}{llllllll}\text { PBS } & 1 & 2 & 3 & 4 & 5 & 6 & 7\end{array}$

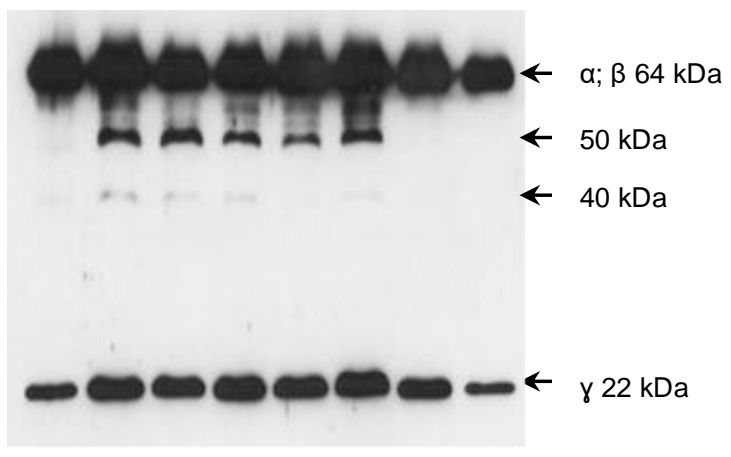

C7

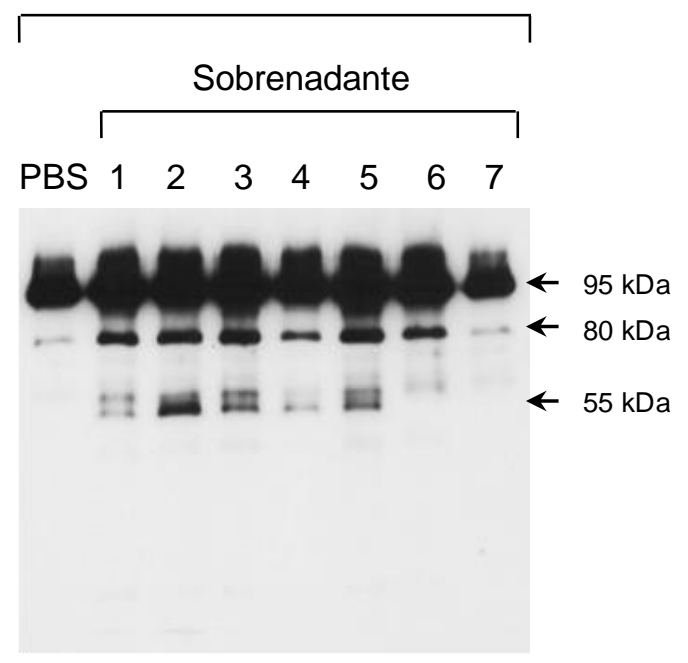

C9

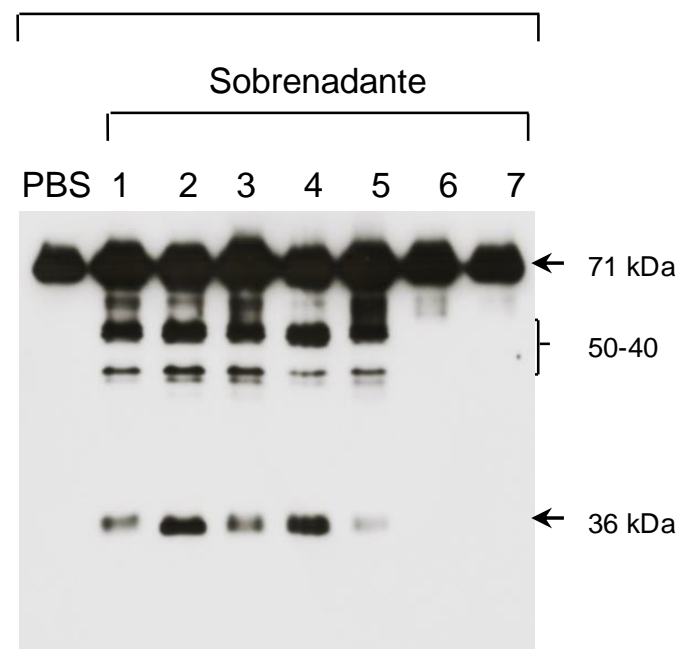

Figura 8 - Proteases secretadas por leptospiras patogênicas clivam proteínas do MAC. Os sobrenadantes de leptospiras patogênicas ( 1 a 5) e saprófitas (6 e 7) foram incubados por $1 \mathrm{~h}$ a $37^{\circ} \mathrm{C}$ com as proteínas C6, C7, C8 ou C9 purificadas. Os produtos das clivagens foram analisados por Western blot utilizando anticorpos específicos contra cada proteína do Complemento. Os nomes das espécies de 1 a 7 encontram-se na Figura 7. Como controle no primeiro poço à esquerda em cada gel, foi aplicada a proteína purificada diluída em PBS sem sobrenadante. As cadeias $\alpha$ e $\beta$ de C8 co-migram no gel, pois ambas possuem $64 \mathrm{kDa}$. 


\subsection{Análise da eficiência proteolítica das proteases secretadas pelas leptospiras patogênicas sobre as proteínas que compõem o MAC}

Para comprovar a eficiência da atividade proteolítica das proteases presentes nos sobrenadantes de leptospiras patogênicas, quantidades relativamente pequenas destes sobrenadantes em relação às concentrações das proteínas C6-C9 foram empregadas (Figura 9). Verificamos que as proteínas C6-C9 continuam a ser clivadas mesmo quando utilizamos duas a vinte vezes menos sobrenadantes $(0,9 \mu \mathrm{g}$ a 0,07 $\mu \mathrm{g})$ que nas reações iniciais $(1,5 \mu \mathrm{g})$, resultando em uma proporção de enzima em relação ao substrato de 1:70 $(0,07 \mu \mathrm{g}$ de proteína total presente nos sobrenadantes sobre $5 \mu \mathrm{g}$ de proteína do Complemento purificada). Nestas condições, o cálculo da proporção enzima/substrato foi realizado considerando-se a concentração total de proteínas presentes no secretado, o que confere uma razão ainda menor de proteases secretadas por leptospiras em relação às proteínas do Complemento, uma vez que diversas proteínas, além das proteases, estão presentes nos sobrenadantes destas bactérias. 

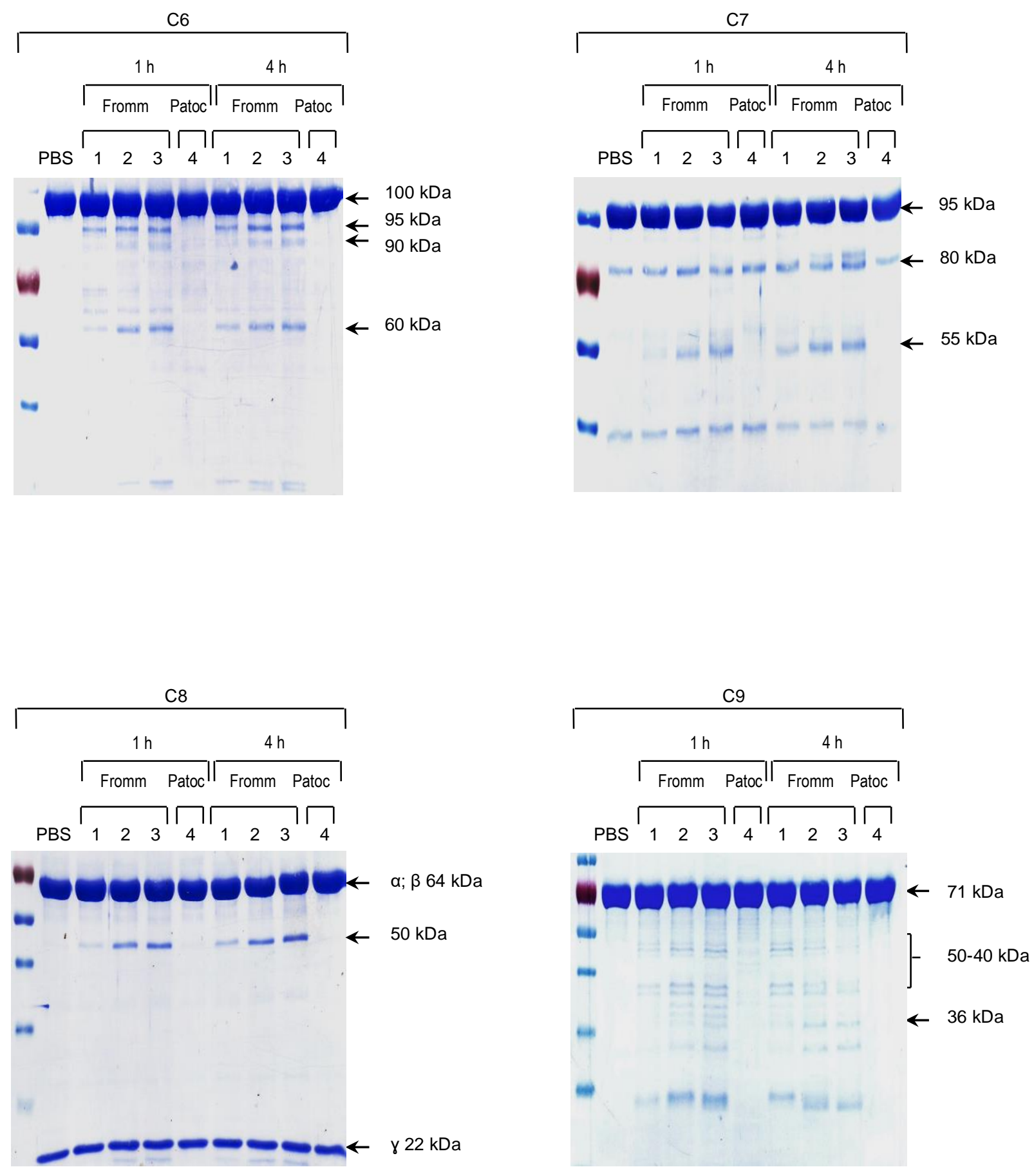

Figura 9 - As proteases secretadas pelas leptospiras patogênicas clivam proteínas do C6-C9 mesmo em quantidades reduzidas. Quantidades crescentes de sobrenadantes da patogênica $L$. interrogans sorovar Kennewicki estirpe Fromm (1) 1:70; (2) 1:15 e (3) 1:5 e da saprófita $L$. biflexa sorovar Patoc estirpe Patoc I (4) 1:5, foram incubadas com as moléculas de complemento por $1 \mathrm{~h}$ a $4 \mathrm{~h}$ a $37{ }^{\circ} \mathrm{C}$. Como controle, as mesmas proteínas foram incubadas apenas com PBS. As clivagens foram analisadas após coloração da membrana de PVDF com Coomassie Blue após transferência das proteínas do gel de poliacrilamida. 


\subsection{Avaliação da atividade proteolítica dos sobrenadantes das leptospiras sobre os componentes do MAC em diferentes tempos de reação}

Nos ensaios anteriores, verificamos que as proteases presentes nos sobrenadantes de leptospiras patogênicas foram capazes de clivar as proteínas C6-C9 do MAC. Neste sentido, decidimos investigar se estas clivagens ocorreriam de forma tempo-dependente, ou seja, se elas se tornariam mais pronunciadas com o aumento do tempo de incubação. Para tanto, realizamos ensaios proteolíticos nos quais os sobrenadantes de leptospiras patogênicas e saprófitas foram incubados separadamente com as moléculas do Complemento por diferentes tempos.

Este ensaio sugere que as proteases presentes apenas nos sobrenadantes de leptospiras patogênicas, apresentam atividade proteolítica sobre as moléculas C6-C9, com apenas 10 min de incubação, sendo possível observar bandas de clivagem em todas as proteínas testadas (Figuras 10 e 11). Além disso, verificamos que com o aumento do tempo de incubação, houve uma intensificação progressiva nas clivagens dessas proteínas. 
C6

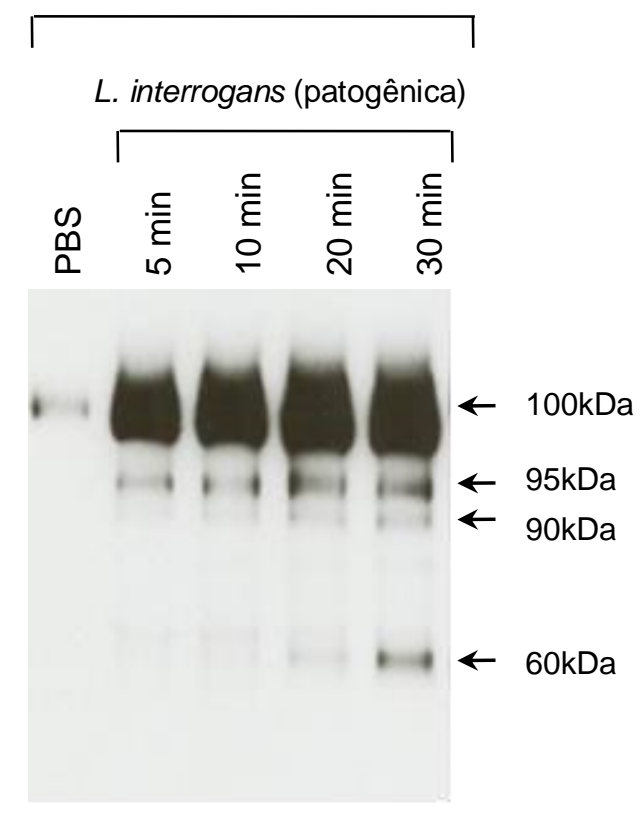

$\mathrm{C} 7$

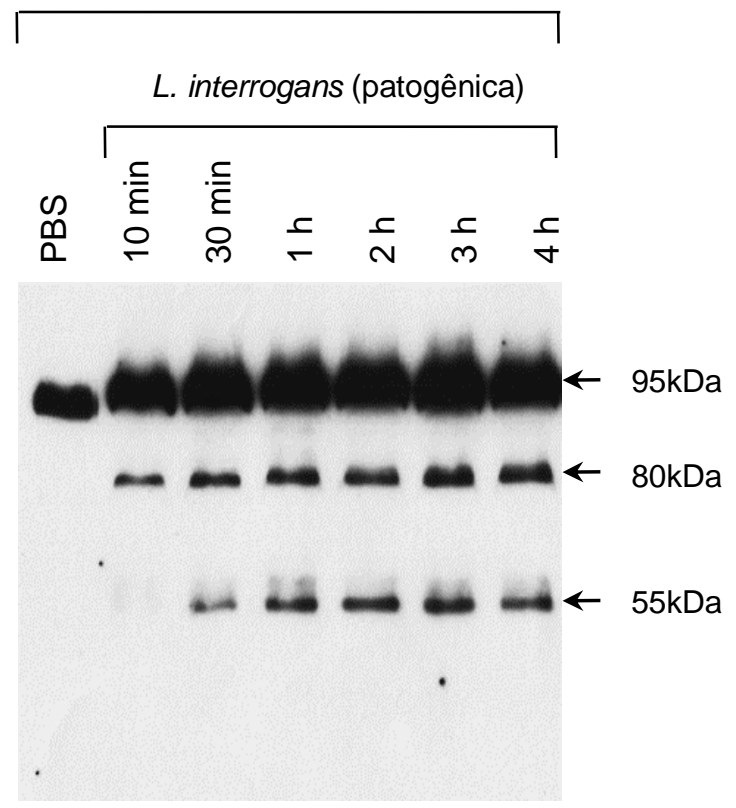

C6

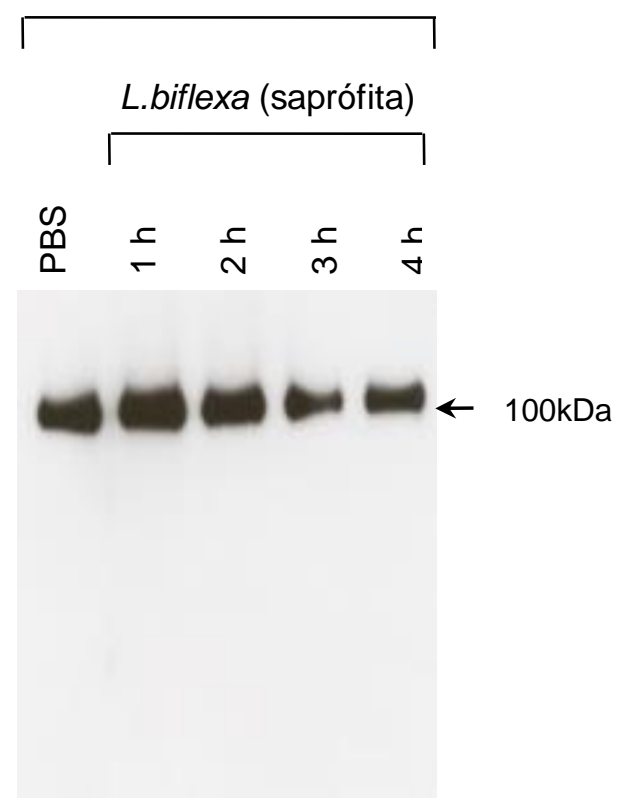

C7

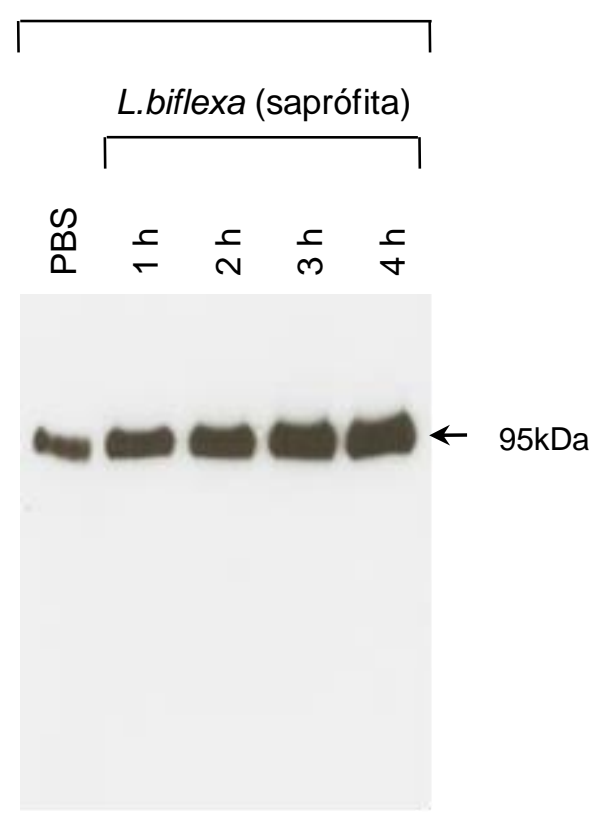

Figura 10 - Proteases secretadas por leptospiras patogênicas clivam as proteínas C6 e C7 purificadas, de modo tempo-dependente. $O$ sobrenadante da patogênica $L$. interrogans sorovar Kennewicki estirpe Fromm e da saprófita L. biflexa sorovar Patoc estirpe Patoc I foram incubados com as proteínas C6 e C7 purificadas, por diferentes tempos a $37^{\circ} \mathrm{C}$. Como controle negativo, as proteínas foram incubadas unicamente com PBS. Os produtos de clivagem foram analisados por Western blot com anticorpos policlonais específicos contra cada proteína. 
C8

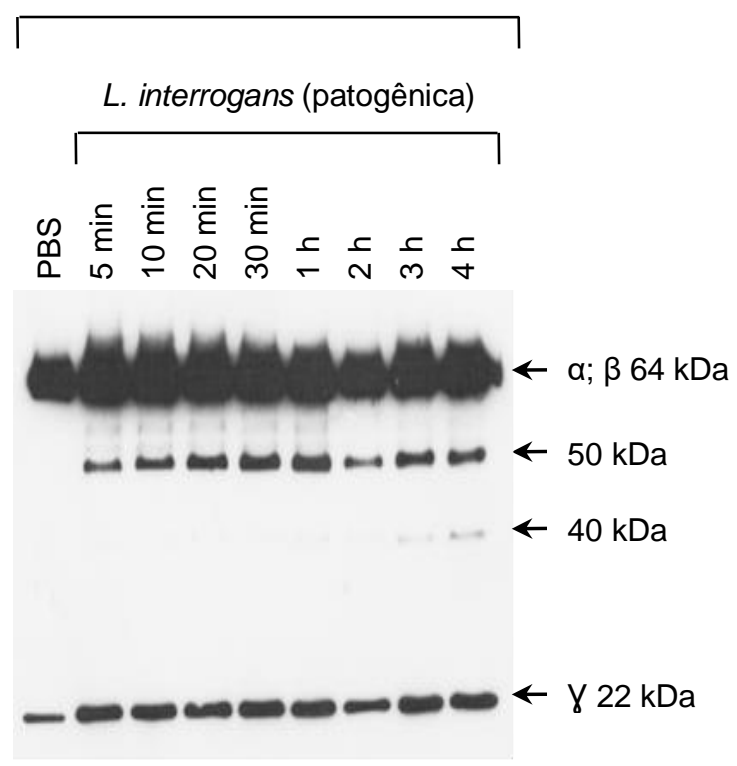

C9

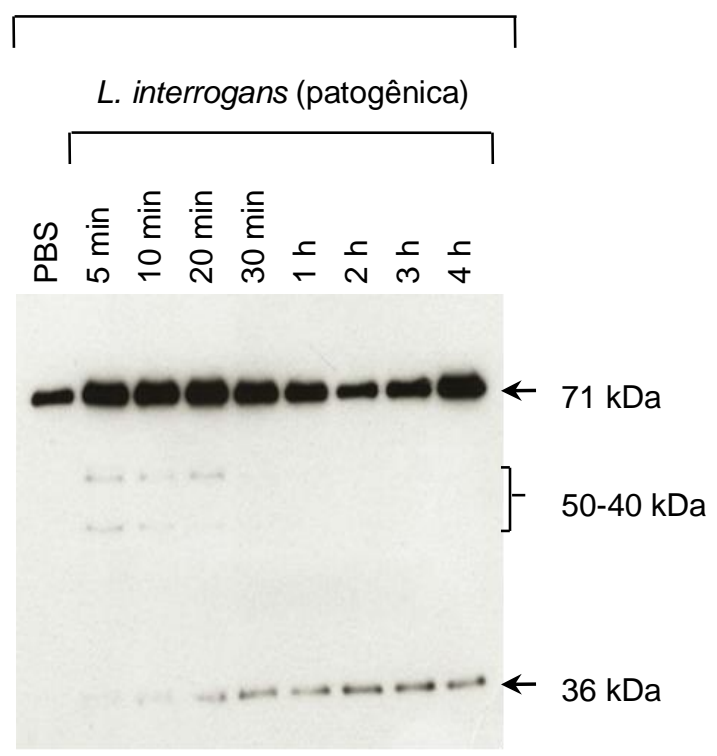

C8

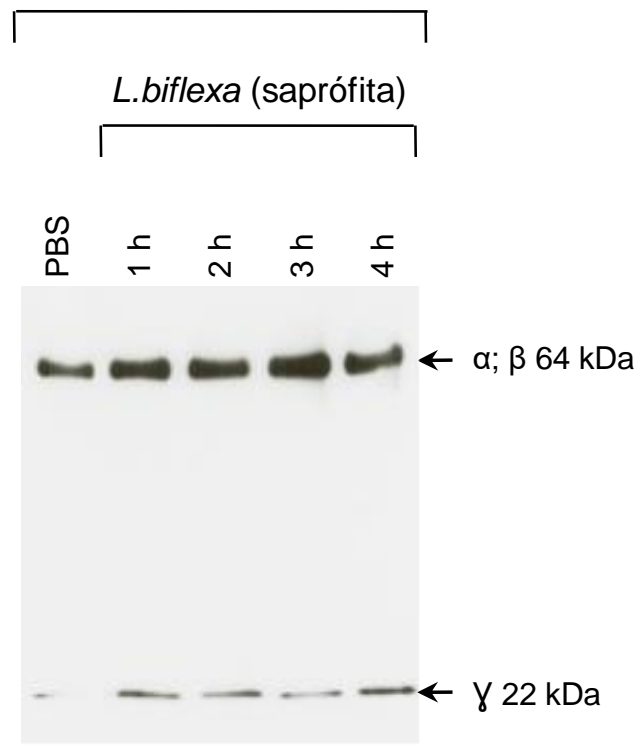

C9

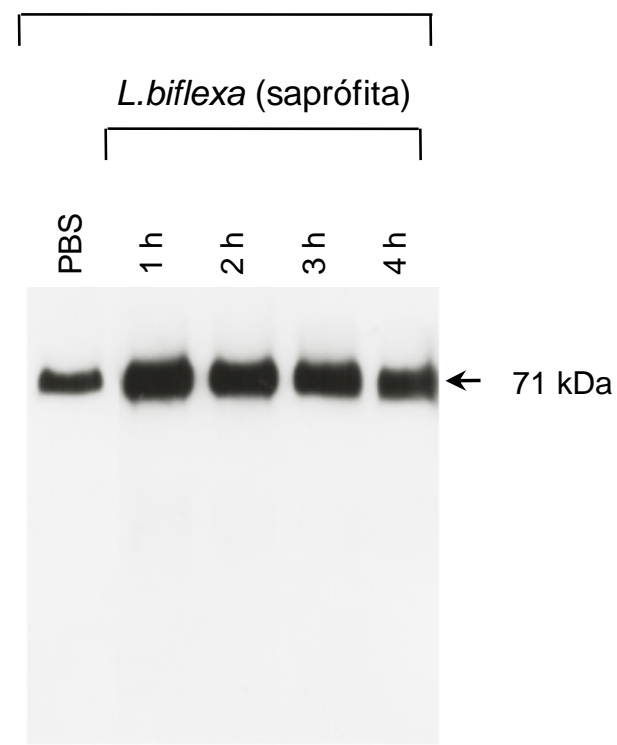

Figura 11 - Proteases secretadas por leptospiras patogênicas clivam as proteínas C8 e C9 purificadas, de modo tempo-dependente. Os sobrenadantes da patogênica $L$. interrogans sorovar Kennewicki estirpe Fromm e da saprófita L. biflexa sorovar Patoc estirpe Patoc I foram incubados com as proteínas C8 e C9 purificadas, por diferentes tempos a $37^{\circ} \mathrm{C}$. Como controle negativo, as proteínas foram incubadas unicamente com PBS. Os produtos de clivagem foram analisados por Western blot com anticorpos policlonais específicos contra cada proteína. 


\subsection{Determinação das classes de proteases secretadas pelas leptospiras patogênicas que clivam as proteínas C6-C9 do MAC}

Nos ensaios anteriores, observamos que as leptospiras patogênicas secretam proteases capazes de clivar as proteínas C6-C9 purificadas. Com a finalidade de identificar quais classes de proteases presentes nos sobrenadantes podem estar relacionadas com estas clivagens, foi realizado um ensaio utilizando inibidores das quatro principais classes de proteases: PMSF (serino proteases), E-64 (cisteíno proteases), 1,10-fenantrolina (metalo proteases) e pepstatina (aspartil proteases).

Os inibidores de proteases foram incubados inicialmente com o sobrenadante de $L$. interrogans sorovar Kennewicki estirpe Fromm, e, em seguida, foram adicionadas separadamente as proteínas C6, C7, C8 e C9 purificadas.

Verificamos que somente o inibidor de metalo proteases 1,10-fenantrolina foi capaz de inibir as clivagens das proteínas do Complemento pelas proteases presentes nos sobrenadantes de leptospiras patogênicas (Figura 12). Assim, este ensaio sugere fortemente que as metalo proteases presentes nessas amostras representam uma das principais classes envolvidas nas clivagens das moléculas do Complemento. 
C6

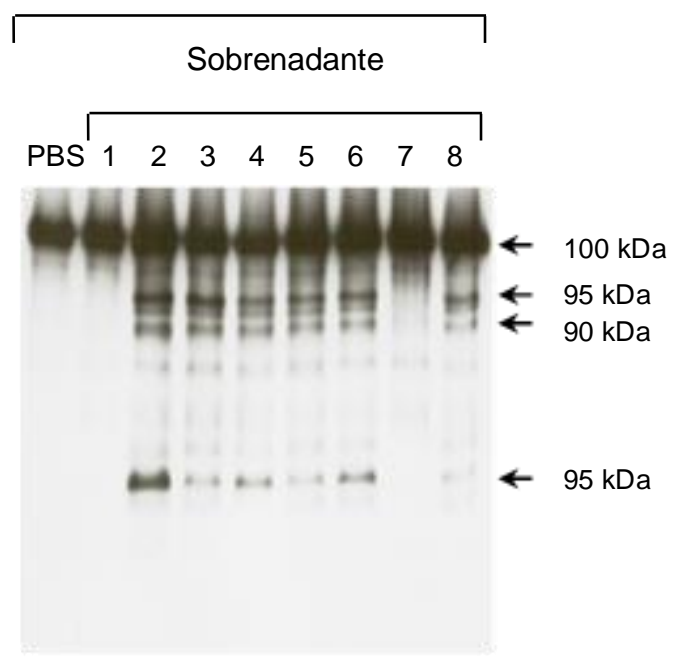

$\mathrm{C} 8$

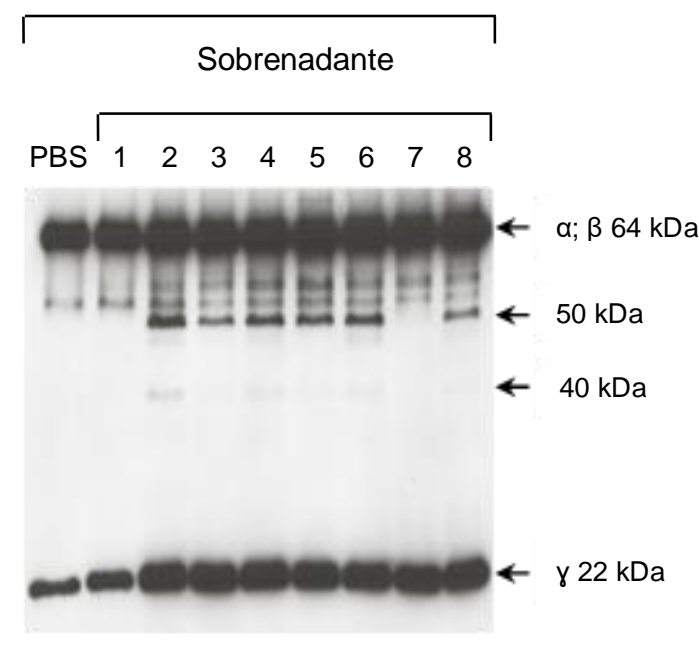

C7

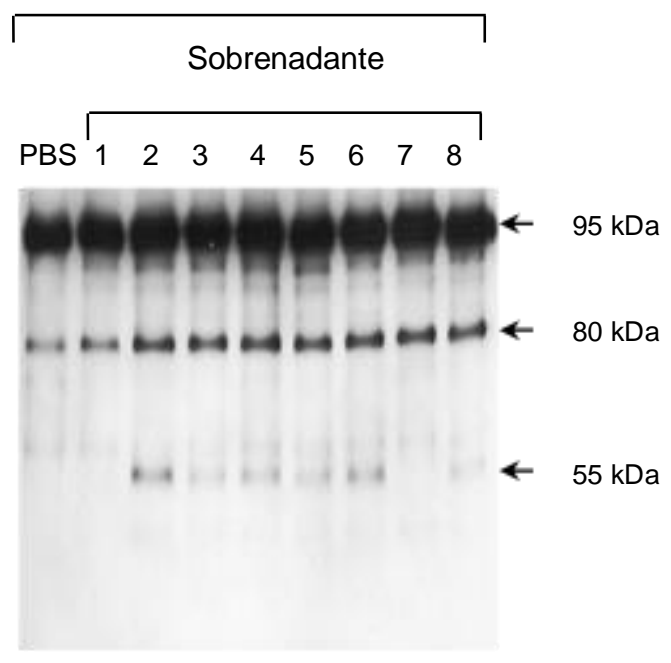

C9

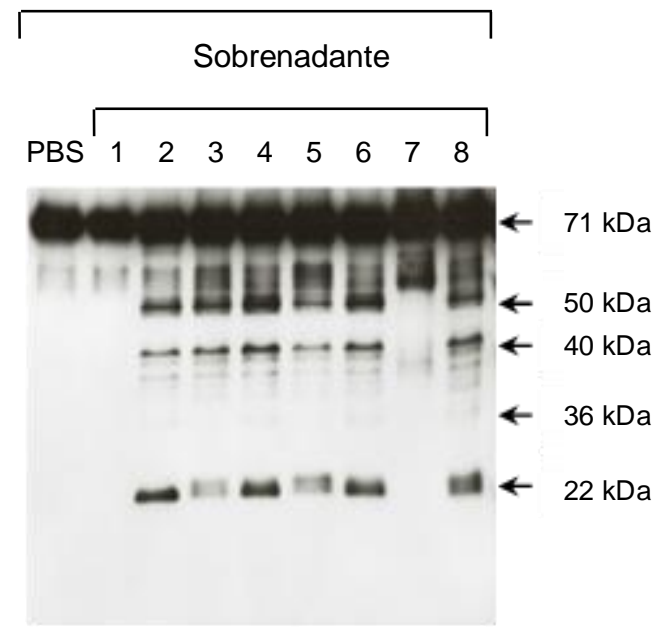

Figura 12 - $O$ inibidor 1,10-fenantrolina apresenta atividade inibitória sobre proteases secretadas por leptospiras patogênicas. $O$ sobrenadante de L. interrogans sorovar Kennewicki estirpe Fromm (poços 1 a 8) foi incubado com os inibidores: (5) PMSF $5 \mathrm{mM}$ (serino proteases), (6) E-64 $28 \mu \mathrm{M}$ (cisteíno proteases), (7) 1,10-fenantrolina $5 \mathrm{mM}$ (metalo proteases) ou (8) Pepstatina $5 \mu \mathrm{M}$ (aspártico proteases), sendo em seguida adicionadas as proteínas C6, C7, C8 ou C9 e a reação foi então incubada por $2 \mathrm{~h}$ a $37^{\circ} \mathrm{C}$. Como controle, as proteínas foram incubadas somente com PBS. Os veículos dos inibidores de protease foram usados como controles nas reações, sendo: (1) PBS + Etanol, (2) Fromm + PBS, (3) Fromm + Etanol, (4) Fromm + Etanol : Água. As clivagens das proteínas C6-C9 foram analisadas por Western blot utilizando anticorpos específicos. Os ensaios foram repetidos duas vezes para comprovar o resultado obtido. 


\subsection{Avaliação da atividade proteolítica dos sobrenadantes de leptospiras patogênicas utilizando SHN como fonte das proteínas do MAC}

Até o presente momento, os ensaios foram realizados utilizando-se as proteínas C6-C9 purificadas, quando observamos que as proteases presentes nos sobrenadantes de leptospiras patogênicas são capazes de clivá-las. Entretanto, é importante investigar a atividade proteolítica dos sobrenadantes sobre as moléculas do complemento presentes no soro, uma condição mais próxima da fisiológica.

Quando incubamos o SHN com os sobrenadantes de leptospiras patogênicas, não foi possível observar a clivagem das proteínas do MAC, diferentemente do que observamos quando utilizamos as proteínas purificadas (Figura 13). Para justificar a ausência de clivagem das proteínas presentes no soro, analisamos algumas hipóteses. Uma delas é a presença de inibidores de proteases no soro tais como a $\alpha_{2}$-macroglobulina, encontrada em condições relativamente elevadas (2-3 mg/mL) (Stevenson et al., 2015). Assim, decidimos investigar a inibição da atividade proteolítica das proteases secretadas pelas leptospiras patogênicas sobre as moléculas purificadas de C6 a C9, em um ensaio utilizando esse inibidor na mesma concentração em que este está presente no SHN (Figura 14). Observamos inibição da atividade proteolítica das proteases secretadas pelas leptospiras patogênicas sobre estas moléculas do Complemento pela $\alpha_{2}$-macroglobulina. Contudo, essa inibição foi parcial e apresentou um padrão distinto daquele observado, quando utilizamos o inibidor de metalo proteases 1,10-fenantrolina. 
C6

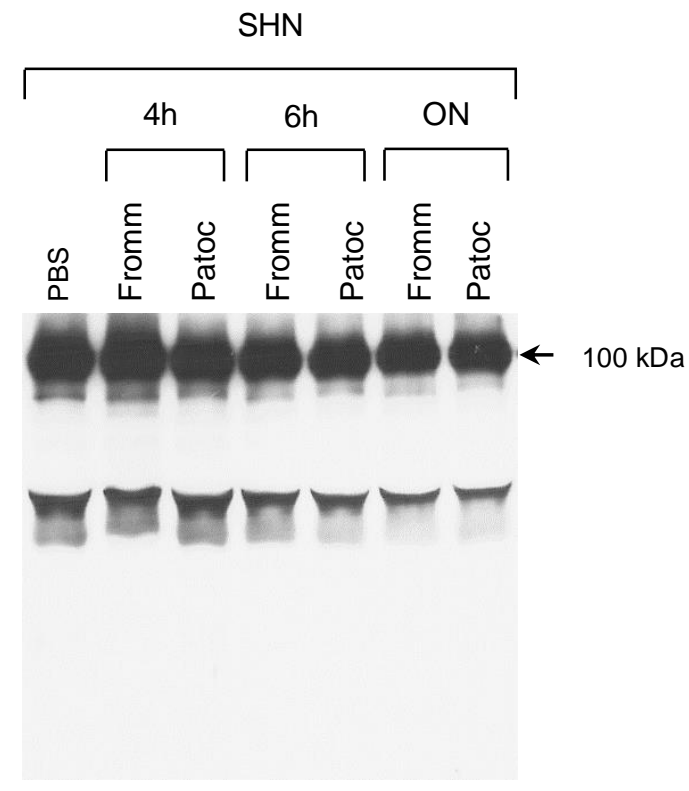

C8

SHN

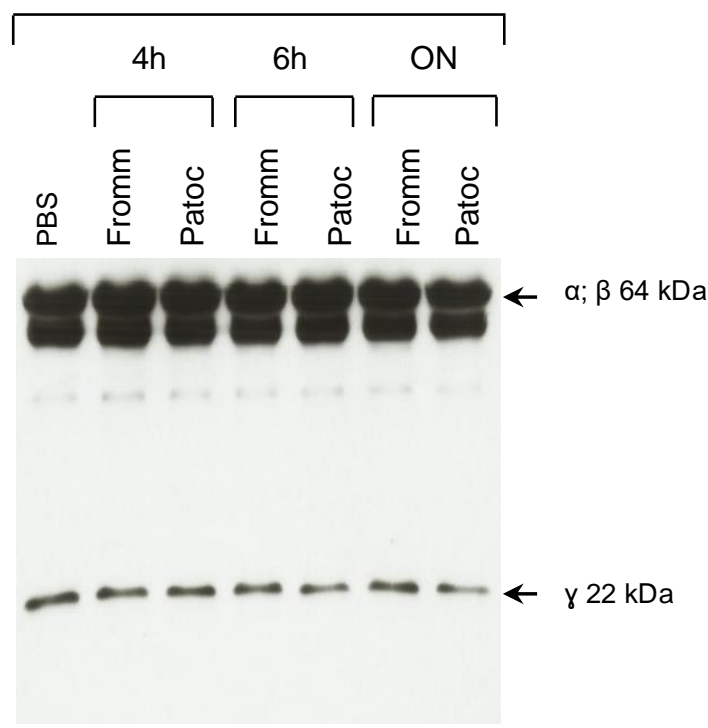

C7

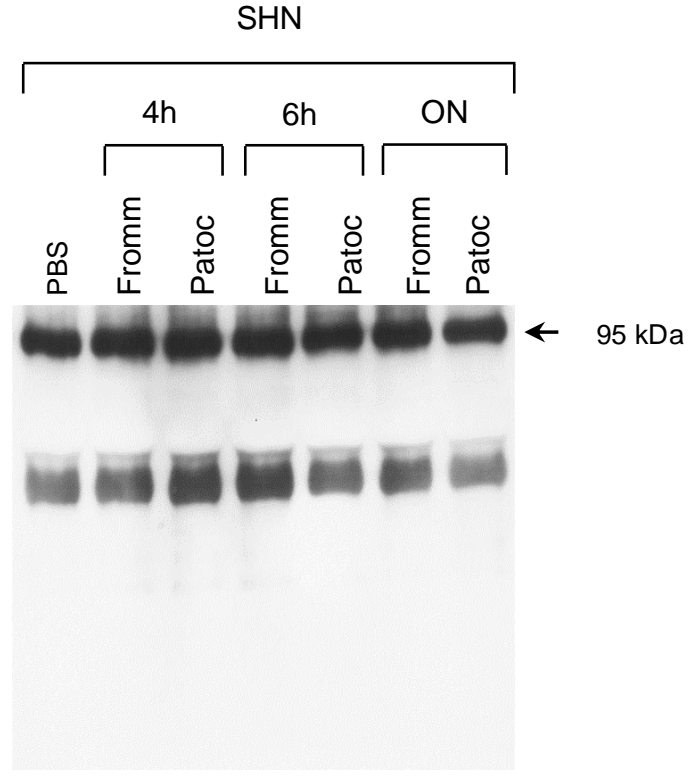

C9

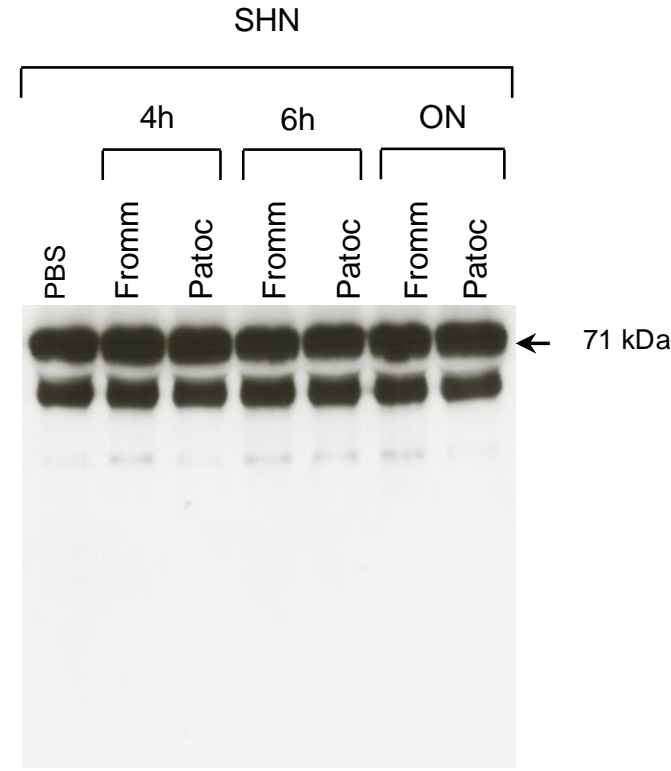

Figura 13 - Análise da atividade proteolítica dos sobrenadantes das leptospiras utilizando SHN como fonte das proteínas C6-C9 do MAC. Os sobrenadantes de L. interrogans sorovar Kennewicki estirpe Fromm e L. biflexa sorovar Patoc estirpe Patoc I foram incubados com SHN como fonte de proteínas do Complemento em diferentes tempos de incubação (4h, $6 \mathrm{~h}$ e $24 \mathrm{~h}$ ) a $37^{\circ} \mathrm{C}$. SHN diluído em PBS foi utilizado como controle e os produtos de clivagem foram analisados por Western blot com anticorpos policlonais específicos contra as proteínas C6, C7, C8 ou C9 do Complemento. 
C6

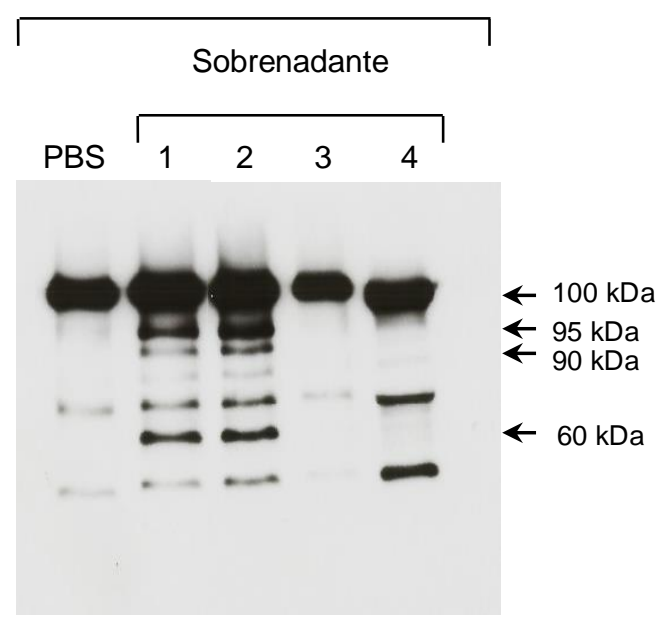

$\mathrm{C} 8$

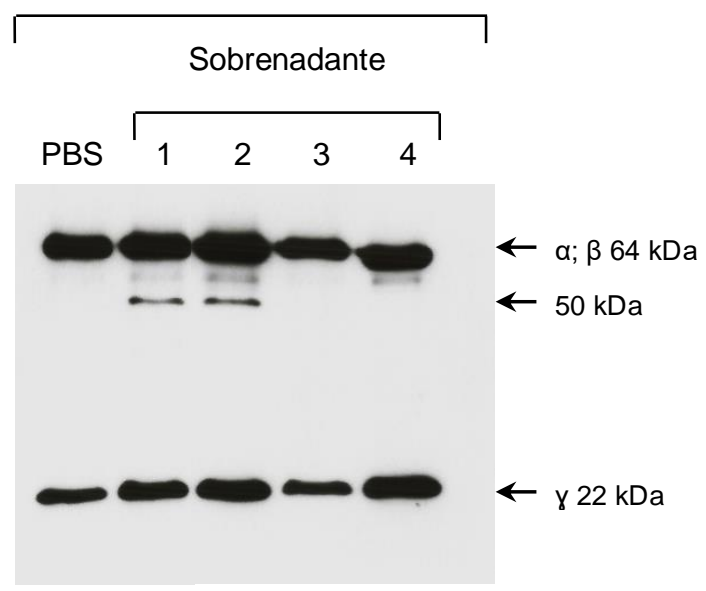

C7

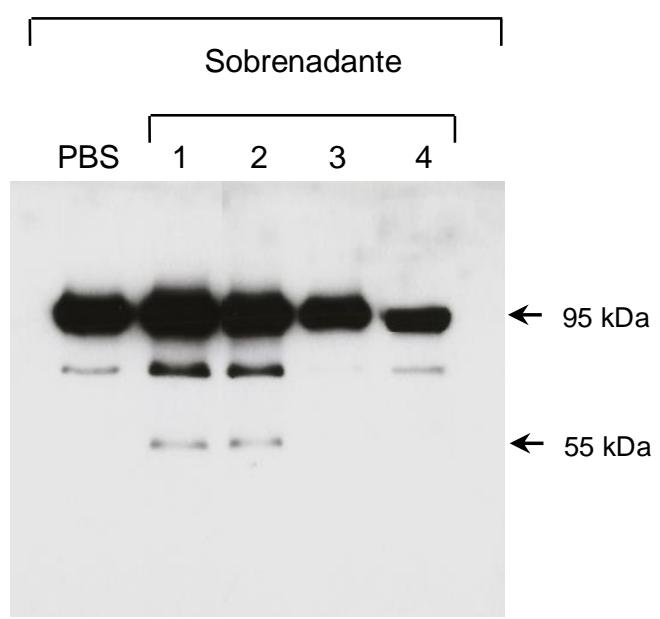

C9

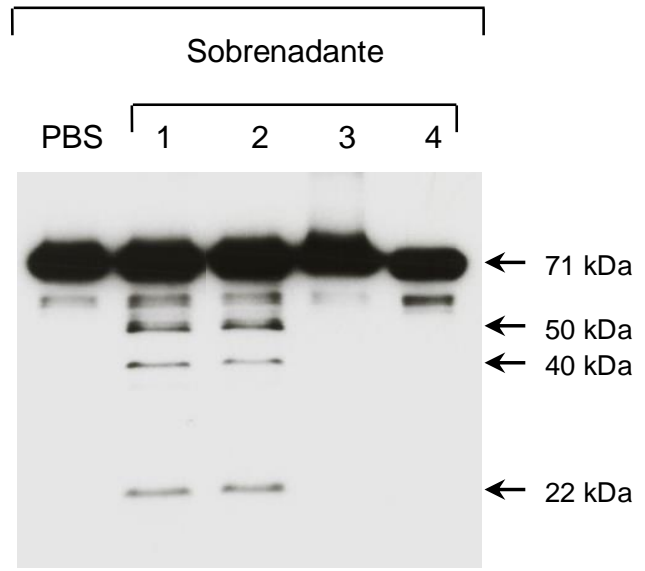

Figura 14 - Análise da atividade inibitória da $\alpha_{2}$-macroglobulina sobre as proteases secretadas pelas leptospiras patogênicas utilizando as proteínas do C6-C9 purificadas como substrato. $O$ sobrenadante da patogênica $L$. interrogans sorovar Kennewicki estirpe Fromm foi incubado por 30 min à temperatura ambiente com: (1) PBS, (2) Etanol, (3) 1,10-fenantrolina e (4) $\alpha_{2}$-macroglobulina, sendo em seguida adicionadas as proteínas C6C9 do MAC e a reação incubada por $2 \mathrm{~h}$ a $37^{\circ} \mathrm{C}$. Como controle, as proteínas foram incubadas com PBS. As clivagens foram analisadas por Western blot utilizando anticorpos policlonais contra tais proteínas do Complemento. 


\subsection{Avaliação da atividade proteolítica dos sobrenadantes das culturas de leptospiras sobre o complexo SC5b-9}

Grande parte do MAC presente na forma solúvel no soro/plasma, encontra-se complexado com a proteína reguladora S-proteína ou Vitronectina (SC5b-9). Este complexo não apresenta atividade lítica, pois é incapaz de interagir com a membrana celular (Monahan e Sodetz, 1980).

Deste modo, decidimos investigar a atividade proteolítica das proteases presentes nos sobrenadantes de leptospiras patogênicas sobre o complexo SC5b-9. Para realizar este ensaio, incubamos por $2 \mathrm{~h}$ a $37{ }^{\circ} \mathrm{C}$ os sobrenadantes das culturas de leptospiras com o complexo SC5b-9 purificado, sendo as reações analisadas em condições redutoras e não-redutoras (Figura 15A).

Conforme observado com as proteínas individualmente, observamos que apenas o sobrenadante de leptospiras patogênicas apresentou atividade proteolítica sobre o complexo SC5b-9. Em condições redutoras, observamos a completa degradação de proteínas de massa molecular entre $43 \mathrm{kDa}$ e $34 \mathrm{kDa}$, e a geração de fragmentos de clivagem de aproximadamente 26 kDa e 17 kDa. Já em condições não redutoras, verificamos acentuada clivagem de proteínas entre $95 \mathrm{kDa}$ e $72 \mathrm{kDa}$, com a geração de diversos fragmentos de menor massa molecular.

Para avaliar o efeito das proteases presentes nos sobrenadantes de culturas de leptospiras sobre as proteínas C6 a C9 complexadas, repetimos o mesmo protocolo de clivagem incubando as membranas separadamente com anticorpos contra cada uma das proteínas do MAC: C6, C7, C8 e C9. Observamos que dentre estas moléculas, as proteases de leptospira têm como alvo o componente C6, sendo este clivado gerando os fragmentos de clivagem 95 kDa e 90 kDa, como observado nos ensaios anteriores (Figura 15B). Entretanto, não houve clivagens sobre as demais moléculas que compõem a Via Terminal: C7, C8 e C9. (Figura 16) 

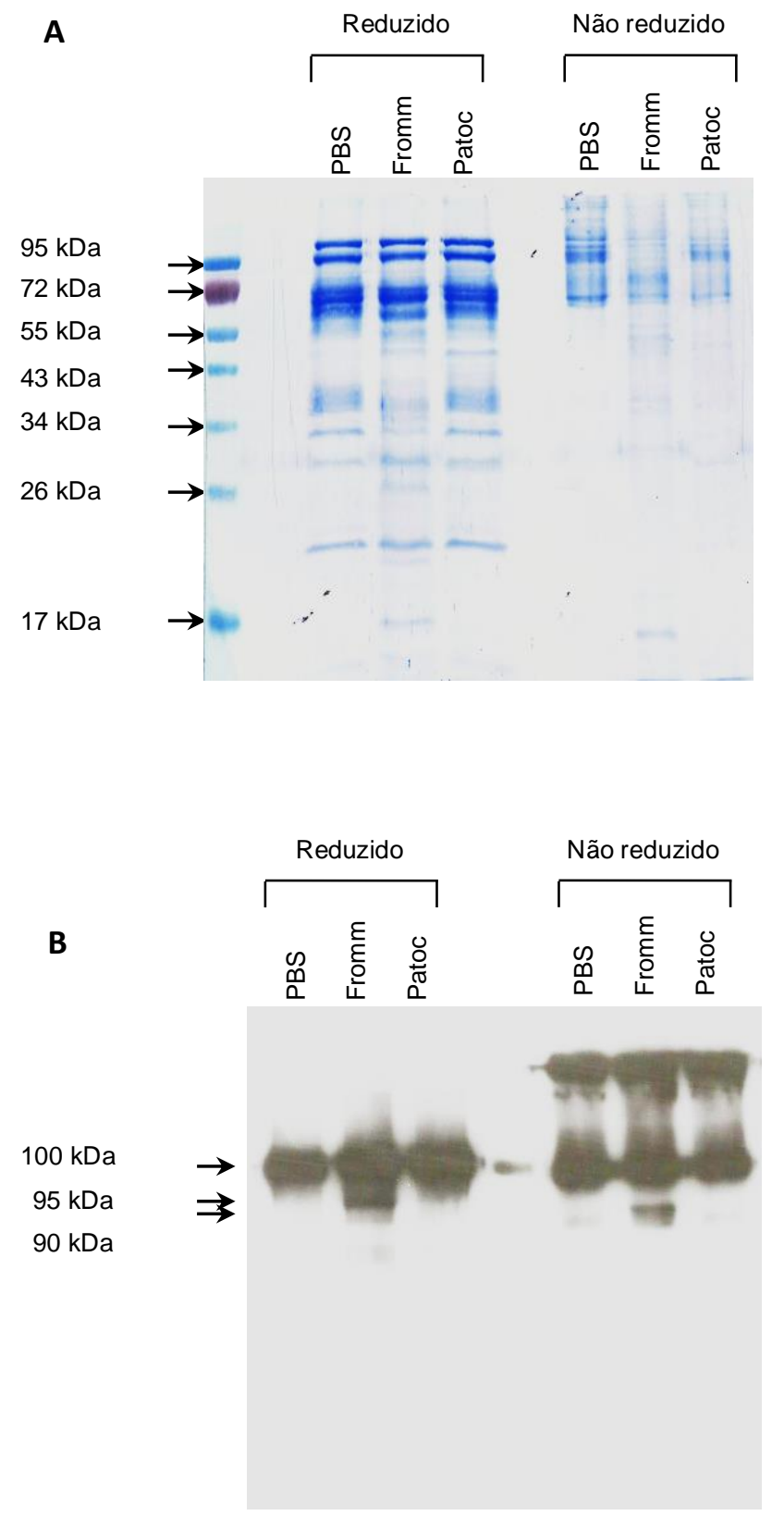

Figura 15 - Análise da atividade proteolítica das proteases presentes nos sobrenadantes das leptospiras patogênicas sobre o complexo SC5b-9 por Western Blot. O complexo SC5b-9 foi incubado por $2 \mathrm{~h}$ a $37{ }^{\circ} \mathrm{C}$ com os sobrenadantes de L. interrogans sorovar Kennewicki estirpe Fromm e L. biflexa sorovar Patoc estirpe Patoc I. Como controle negativo, aplicamos no gel SC5b-9 unicamente diluído em PBS. As clivagens foram analisadas por SDS-PAGE em condições redutoras (tampão de amostra contendo $\beta$ mercaptoetanol e aquecimento a $96{ }^{\circ} \mathrm{C}$ por $3 \mathrm{~min}$ ) e não-redutoras (tampão de amostra sem $\beta$-mercaptoetanol e sem aquecimento). (A) As proteínas e seus fragmentos foram transferidos para membrana de PVDF, sendo corada posteriormente com Coomassie Brilliant Blue. (B) As clivagens foram analisadas por Western blot empregando anti-C6 humano. 

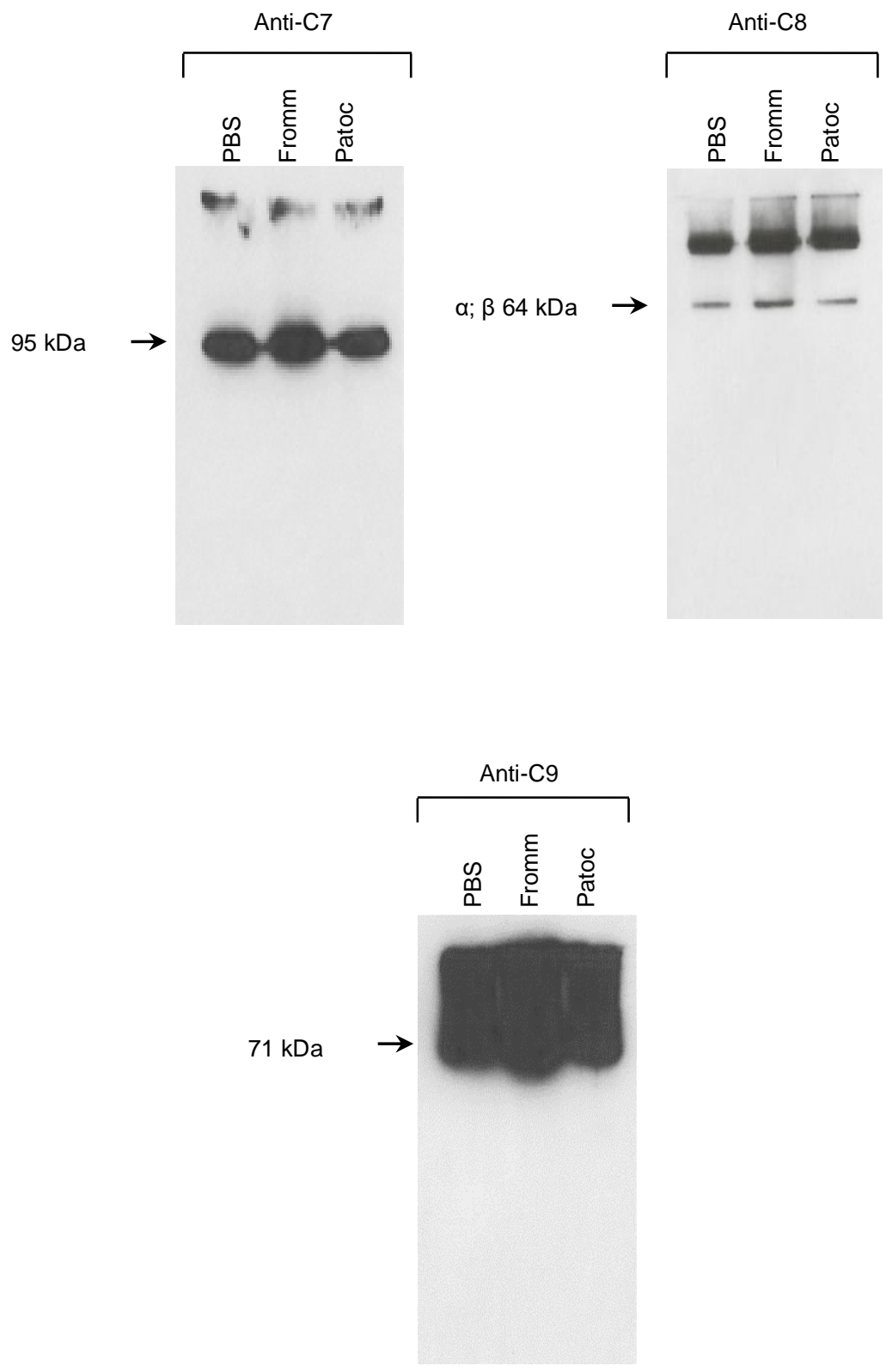

Figura 16 - Análise da atividade proteolítica das proteases presentes nos sobrenadantes das leptospiras patogênicas sobre o complexo SC5b-9. O complexo SC5b-9 foi incubado com o sobrenadante das culturas de L. interrogans sorovar Kennewicki estirpe Fromm e L. biflexa sorovar Patoc estirpe Patoc I por $2 \mathrm{~h}$ a $37^{\circ} \mathrm{C}$. Como controle negativo, esse complexo foi incubado unicamente com PBS. As clivagens foram analisadas por SDSPAGE em condições não-redutoras (tampão de amostra sem $\beta$-mercaptoetanol e sem aquecimento). Os produtos de clivagem foram analisados por Western blot com anticorpos policlonais específicos contra as proteínas C7, C8 ou C9 do Complemento. 


\subsection{Análise da atividade proteolítica da Termolisina sobre os componentes C6-C9 purificados e o complexo solúvel SC5b-9}

Os ensaios de inibição proteolítica mostraram que as metalo proteases são uma das principais classes de enzimas responsáveis pelas clivagens das proteínas C6-C9 obtidas com os sobrenadantes das leptospiras patogênicas. Dentre as proteases secretadas, nosso grupo conseguiu comprovar que a Termolisina (Figura 17), uma metalo protease expressa exclusivamente por espécies patogênicas de leptospira, é capaz de clivar a molécula C3 do Complemento (Fraga et al., 2014b). Nesse sentido, consideramos que seria relevante testar a atividade desta protease sobre as proteínas que compõe o MAC e o complexo solúvel SC5b-9.

Para analisar a atividade proteolítica da Termolisina recombinante, esta protease foi incubada separadamente com as proteínas purificadas C6, C7, C8 e C9 e também com o complexo solúvel SC5b9, sendo as clivagens analisadas por Western blot empregando anticorpos específicos.

Neste ensaio observamos que somente o componente C6 foi alvo de clivagem pela Termolisina recombinante (Figura 18), diferentemente de C7, C8 e C9 os quais não apresentaram fragmentos de clivagem (Figura 19). De forma interessante, a Termolisina foi capaz de clivar a proteína C6, tanto purificada quanto como parte integrante do complexo solúvel SC5b9. A clivagem de C6 pela Termolisina possui um padrão semelhante ao observado com ela purificada, quando utilizamos o sobrenadante total das leptospiras patogênicas como fonte de proteases, com produtos de degradação em comum (banda de 90 $\mathrm{kDa}$ ). Contudo, podemos observar que a clivagem de C6 é mais pronunciada, quando utilizamos o sobrenadante total em comparação com a Termolisina recombinante (banda adicional de $60 \mathrm{kDa})$. 


\section{Termolisina}

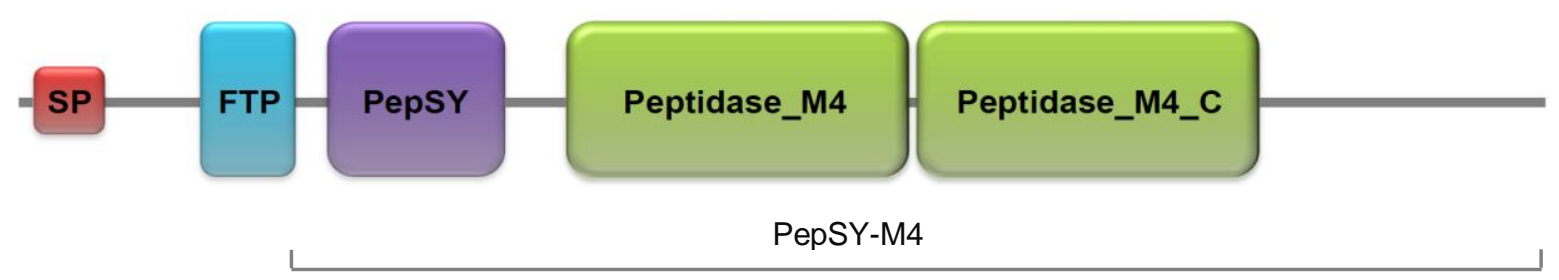

Figura 17 - Representação esquemática da Termolisina codificada pelo gene LIC13322 de $L$. interrogans sorovar Copenhageni. A análise da sequência primária da termolisina pelos programas SMART e PSORTb (Letunic et al., 2012; Yu et al., 2010) revelou que esta proteína possui peptídeo sinal para secreção (SP), pró-domínios FTP e PepSY, e domínios catalíticos Peptidase_M4 e M4_C. A Termolisina recombinante compreende a região delimitada PeSY-M4 (Fraga et al., 2014b)

Anti-C6

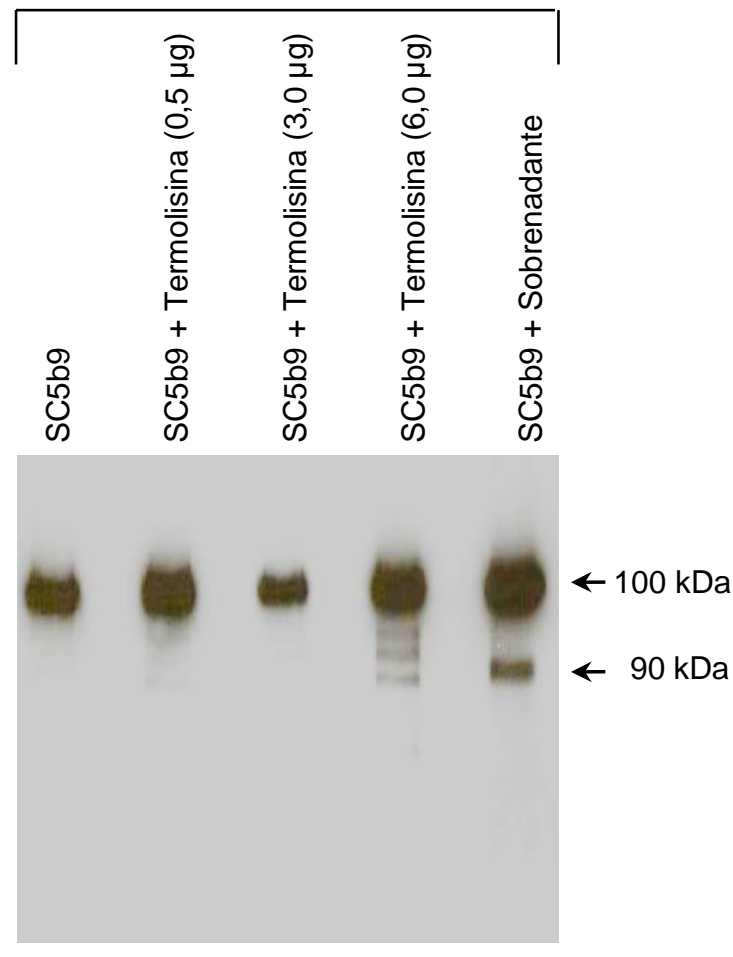

Anti-C6

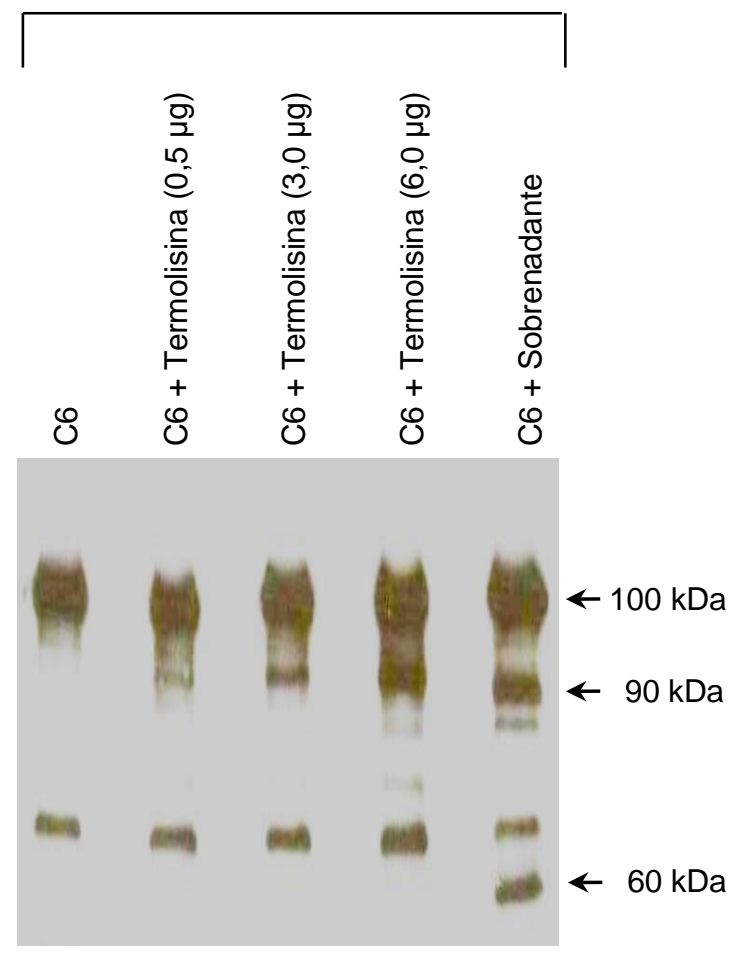

Figura 18 - A Termolisina recombinante possui atividade proteolítica sobre componente C6 do MAC, tanto na forma purificada quanto como parte integrante do complexo solúvel SC5b9. Tanto a proteína C6 purificada quanto o complexo solúvel SC5b-9 foram incubados com quantidades crescentes de Termolisina recombinante $(0,5 \mathrm{a} 6 \mu \mathrm{g})$ por $4 \mathrm{~h}$ a $37{ }^{\circ} \mathrm{C}$. O sobrenadante da leptospira patogênica L. interrogans sorovar Kennewiki estirpe Fromm também foi incubado com C6 e SC5b-9 nas mesmas condições. As clivagens foram analisadas por Western blot utilizando anticorpo contra a proteína C6 do Complemento. 
C7

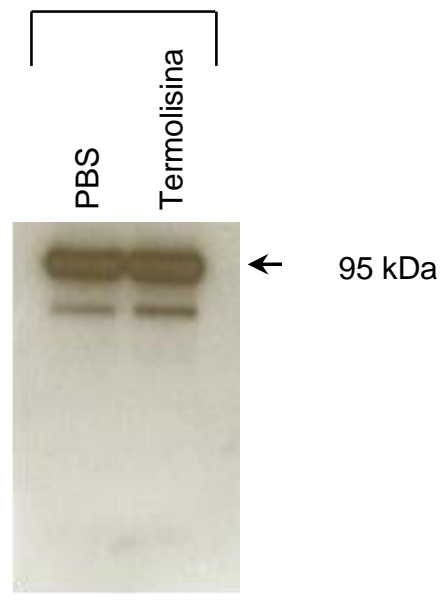

C8

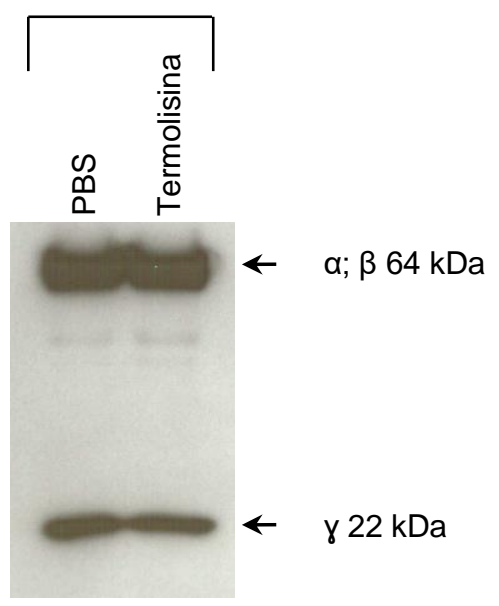

C9

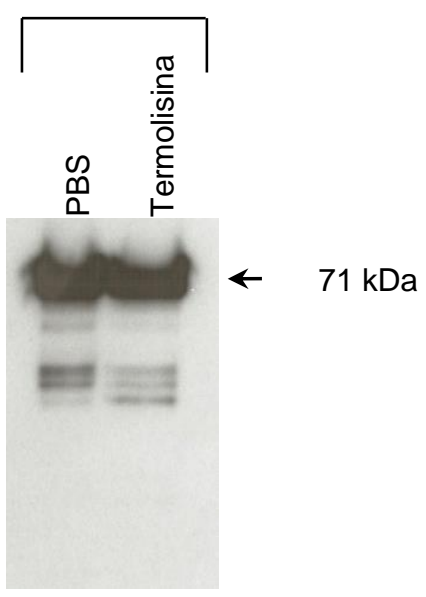

Figura 19 - A Termolisina recombinante não possui atividade proteolítica sobre os componentes C7, C8 e C9 presentes no complexo SC5b-9. As proteínas purificadas foram incubadas com a maior concentração de Termolisina recombinante $(6 \mu \mathrm{g})$ por $2 \mathrm{~h}$ a $37^{\circ} \mathrm{C}$. Como controle, as proteínas foram incubadas apenas com PBS. As clivagens foram analisadas por Western blot utilizando anticorpos específicos contra cada proteína do Complemento. 


\subsection{Análise da interação da Termolisina com o componente C6 do MAC}

O ensaio de atividade proteolítica com a Termolisina recombinante demonstrou que, dentre as proteínas C6-C9, esta protease tem como alvo único o componente $\mathrm{C} 6$, sendo capaz de clivá-lo tanto isoladamente quanto como parte integrante do complexo solúvel SC5b9.

Para que ocorra a proteólise, é necessário que haja interação entre a enzima e seu substrato. Neste contexto, decidimos avaliar a interação entre a Termolisina e o componente C6. Para analisar essa interação efetuamos um Western blot com sobreposição (Figura 20A) e estimamos o valor da constante de dissociação $(K d)$ entre as duas proteínas por ELISA (Enzyme Linked Immuno Sorbent Assay) (Figura 20B). Verificamos que a interação entre a Termolisina e C6 foi comprovada pelos dois ensaios, sendo obtido um $K d$ com valor de 31,8 $\pm 2.2 \mathrm{nM}$.

Em seguida, uma vez observada a interação entre a Termolisina e o componente C6, investigamos se esta interação seria dependente de força-iônica e se seria afetada pela adição de heparina. Para tanto, efetuamos um ensaio no qual a Termolisina foi imobilizada e a proteína C6 foi adicionada na presença de concentrações crescentes de $\mathrm{NaCl}(0$ a $600 \mathrm{mM})$ ou diferentes quantidades de heparina $(0,05$ a $1 \mu \mathrm{g})$ (Figura 21). Observamos que a interação entre C6 e a Termolisina foi afetada somente quando utilizamos elevadas concentrações de $\mathrm{NaCl}(600 \mathrm{mM})$ e com o aumento progressivo da quantidade de heparina (0,5 a 1,0 $\mu \mathrm{g})$, foi observada uma inibição dose-dependente, sugerindo que a Termolisina pode interagir com C6 através de sítios de ligação à heparina e que altas concentrações salinas pode prejudicar parcialmente essa interação.

De fato, a heparina pode se associar às moléculas $\mathrm{C} 6, \mathrm{C} 8$ e $\mathrm{C} 9$, entretanto é incapaz de se ligar aos componentes C5 e C7 da Via Terminal. Em um estudo realizado por Sahu e Pangburn os autores sugeriram que o sítio de inibição da formação do complexo C5b-7 se encontra em C6, uma vez que a heparina não se liga ao C5 nem ao C7. As concentrações de heparina livre in vivo raramente atingem níveis suficientes para inibir a ativação das Vias Clássicas e Alternativa. Portanto, a inibição da montagem do complexo C5b-9 pode ser importante para prevenir a geração de danos mediados pelo Complemento (Sahu e Pangburn, 1993). 
A.

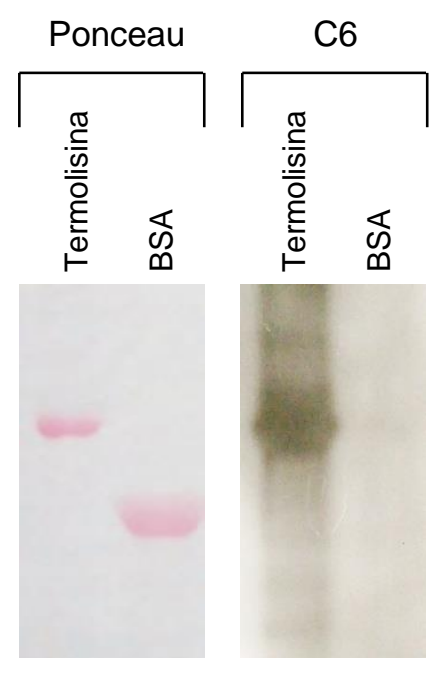

B.

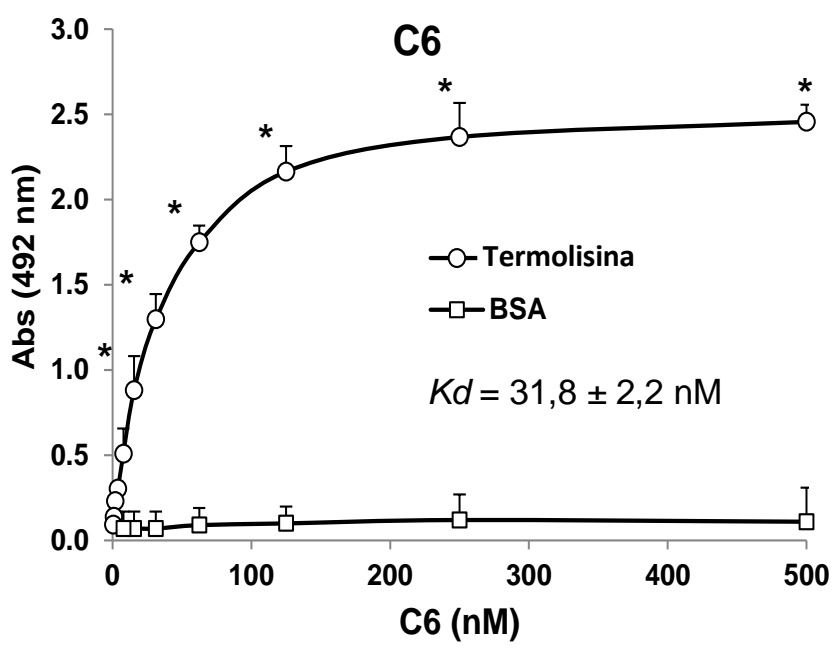

Figura 20 - A Termolisina recombinante interage com o componente C6 do MAC. (A) Western blot com sobreposição. (Esquerda) A Termolisina recombinante e BSA foram submetidos a SDS-PAGE $12 \%$, sob condições não redutoras e transferidos para uma membrana de nitrocelulose a qual foi corada com Ponceau S. (Direita) A membrana contendo as proteínas imobilizadas foi incubada com uma solução contendo o componente C6 purificado, sendo a ligação entre as proteínas detectada com anticorpo policlonal anti-C6. (B) ELISA. A Termolisina recombinante $(1 \mu \mathrm{g})$ foi imobilizada em placas de microdiluição e, após bloqueio dos sítios inespecíficos, foram adicionadas diferentes quantidades de C6. A ligação entre a Termolisina e C6 foi detectada com anticorpo policlonal anti-C6. BSA foi incluído como controle negativo. Cada ponto representa o valor médio de absorbância a $492 \mathrm{~nm} \pm$ DP de três experimentos independentes, cada um realizado em duplicata. A ligação entre C6 e a Termolisina foi comparada com a ligação destas moléculas ao BSA pelo teste t 2 -tailed $(* \mathrm{p}<0,05)$. A constante de dissociação $(K d)$ das interações foi calculada pela equação $\mathrm{Y}=\mathrm{Bmax} * \mathrm{X} /$ $(\mathrm{Kd}+\mathrm{X})$ utilizando o programa GraphPad Prism 5.0 (GraphPad Software, Inc.). 
A

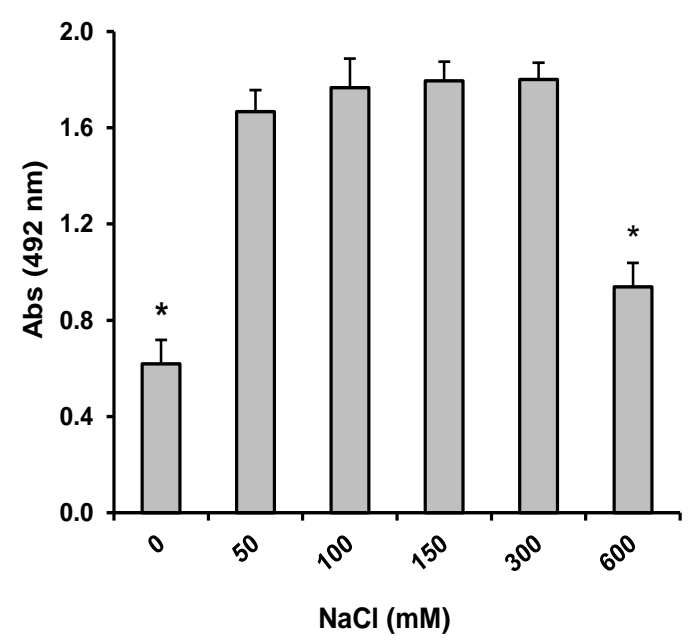

B.

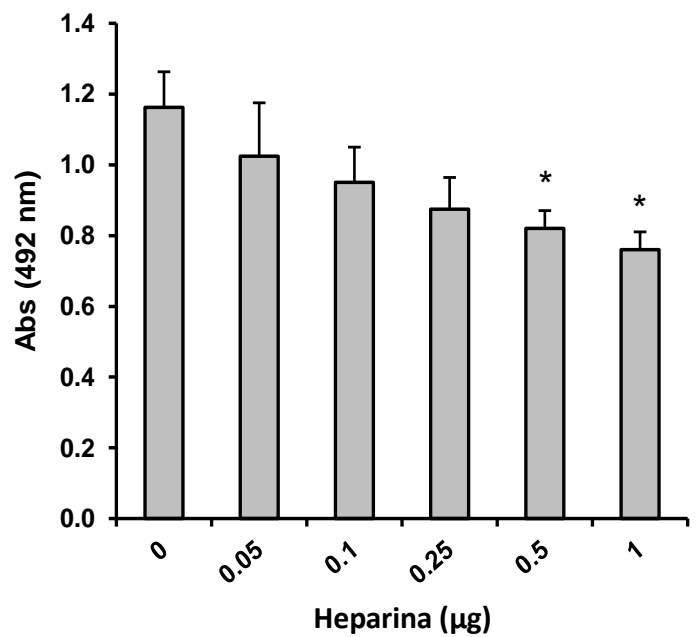

Figura 21 - A interação da Termolisina com o componente C6 do MAC é dependente de força iônica e é afetada pela adição de heparina. Placas de microdiluição foram revestidas com Termolisina recombinante $(1 \mu \mathrm{g})$ e, após bloqueio dos sítios inespecíficos, foi adicionado o componente $\mathrm{C} 6$ do Complemento na presença de concentrações crescentes de $\mathrm{NaCl}(0$ a $600 \mathrm{mM})$ ou diferentes quantidades de heparina $(0,05$ a $1 \mu \mathrm{g})$. A ligação entre a Termolisina e C6 foi detectada com anticorpo policlonal anti-C6. Cada ponto representa o valor médio de absorbância a $492 \mathrm{~nm} \pm \mathrm{SD}$ de três experimentos independentes, cada um realizado em duplicata. Os dados foram analisados utilizando o teste ANOVA $(* \mathrm{p}<0,05)$. 


\subsection{Análise da interação da Termolisina recombinante com os componentes C7, C8 e C9 do MAC}

Nos ensaios anteriores demonstramos a clivagem e a interação entre o componente C6 do MAC e a Termolisina de leptospira. Verificamos também que a protease recombinante não foi capaz de clivar os componentes C7, C8 e C9 da Via Terminal. Entretanto, sabemos que há diversos domínios em comum entre estas proteínas e a molécula C6 do Complemento. Neste sentido, perguntamo-nos se a Termolisina recombinante, apesar se não exercer atividade proteolítica sobre os demais componentes do MAC, poderia interagir com estas moléculas separadamente, o que resultaria em um efeito adicional de inibição por interação direta, caracterizando assim um novo mecanismo de evasão atribuído a protease de leptospira.

A interação entre a Termolisina e os componentes C7, C8 e C9 do MAC foi analisada por ELISA (Figura 22). A Termolisina recombinante foi imobilizada e diferentes quantidades das proteínas do MAC foram adicionadas, separadamente, para possibilitar o cálculo da constante de dissociação $(K d)$. Nesse ensaio observamos que houve interação entre a protease de leptospira e os componentes C7, C8 e C9 do Complemento, com valores de $K d$ de $17,8 \pm 1,3 \mathrm{nM} ; 62,0 \pm 7,1$ e $56,8 \pm 5,2$, respectivamente. 

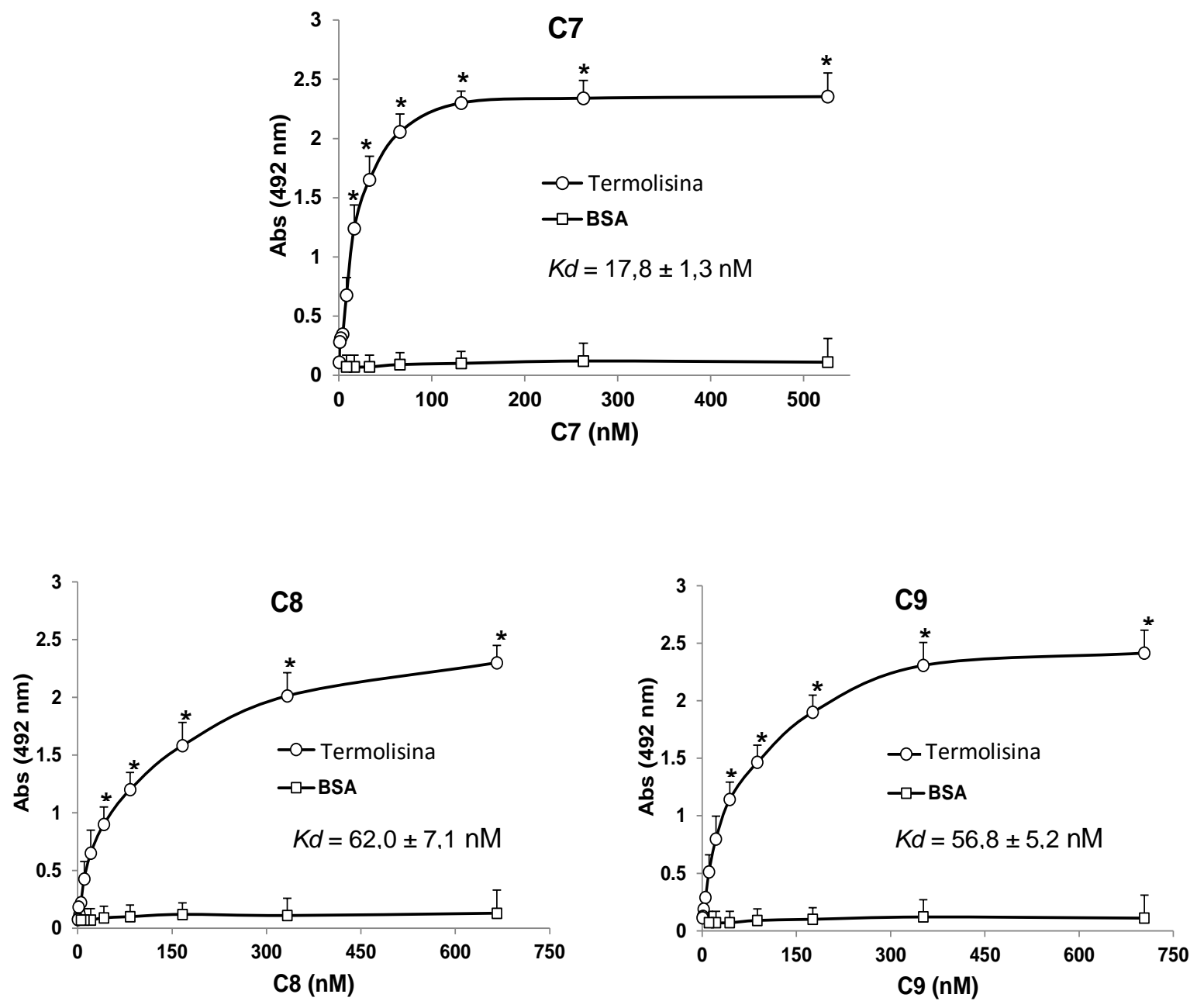

Figura 22 - A Termolisina interage com os componentes C7, C8 e C9 do MAC. A Termolisina recombinante $(1 \mu \mathrm{g})$ foi imobilizada em placas de microdiluição e, após bloqueio dos sítios inespecíficos, foram adicionadas diferentes quantidades de $\mathrm{C} 7, \mathrm{C} 8$ ou C9. A ligação entre a Termolisina e os componentes do Complemento foi detectada com anticorpo específico contra cada proteína. BSA foi incluído como controle negativo. Cada ponto representa o valor médio de absorbância a $492 \mathrm{~nm} \pm$ DP de três experimentos independentes, cada um realizado em duplicata. A ligação entre a Termolisina recombinante e proteínas $\mathrm{C} 7, \mathrm{C} 8$ e C9 foi comparada com a ligação destas moléculas ao BSA pelo teste $\mathrm{t} 2$-tailed $(* \mathrm{p}<0,05)$. A constante de dissociação $(K d)$ das interações foi calculada pela equação $\mathrm{Y}=\mathrm{B} \max * \mathrm{X} /(\mathrm{Kd}+\mathrm{X})$ utilizando o programa GraphPad Prism 5.0 (GraphPad Software, Inc.). 


\subsection{Análise da capacidade da Termolisina em inibir a formação do MAC}

A Termolisina recombinante de Leptospira interrogans apresentou a capacidade de clivar a proteína C6 e também de interagir com esta e as demais moléculas finais que compõem o MAC: C7, C8 e C9. Com a finalidade de comprovar a capacidade inibitória da Termolisina sobre a formação do MAC, efetuamos um ensaio no qual as proteínas C7, C8 e C9 foram pré-incubadas com a Termolisina recombinante e posteriormente adicionadas a eritrócitos de carneiro previamente revestidos com o complexo C5b6. Neste ensaio funcional verificamos que a Termolisina foi capaz de inibir a hemólise dos eritrócitos de modo dosedependente (Figura 23), comprovando assim que a protease secretada pelas leptospiras patogênicas é capaz de inibir a formação do MAC clivando C6, contribuindo assim para anular a função lítica do Complemento.

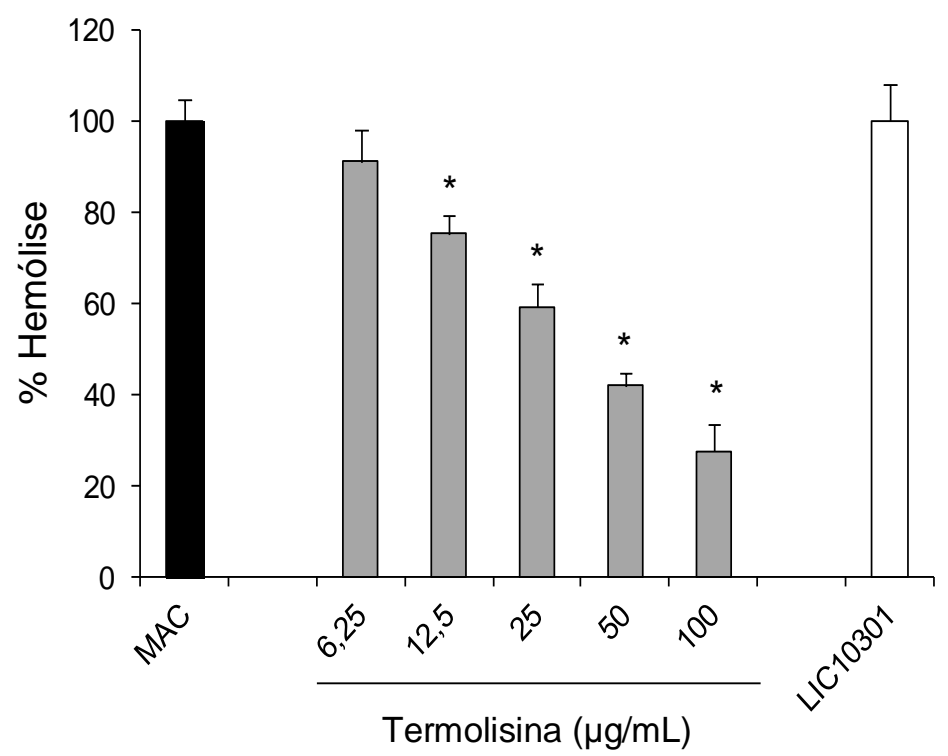

Figura 23 - A Termolisina recombinante inibe a formação do MAC sobre eritrócitos de carneiro de forma concentração dependente. A Termolisina recombinante $(6,25$ a $50 \mu \mathrm{g} / \mathrm{ml})$ foi pré-incubada com $\mathrm{C} 7, \mathrm{C} 8$ e $\mathrm{C} 9$, sendo em seguida esta mistura adicionada a hemácias de carneiro previamente revestidas com C5b6. Após incubação de 30 min a 37 ${ }^{\circ} \mathrm{C}$, a quantidade de hemoglobina livre no sobrenadante, que representa as células lisadas, foi medida a $540 \mathrm{~nm}$. A proteína recombinante de L. interrogans LIC10301 (50 $\mu \mathrm{g} / \mathrm{ml}$ ) foi utilizada como controle negativo. Cada ponto representa o valor médio de absorbância a $492 \mathrm{~nm} \pm$ DP de três experimentos independentes, cada um realizado em duplicata. A lise obtida na ausência da Termolisina foi considerada como 100\% (MAC). Os dados foram analisados utilizando o teste estatístico ANOVA $(* \mathrm{p} \leq 0,05)$. 
5 DISCUSSÃO 
A leptospirose é uma zoonose causada por bactérias espiroquetas do gênero Leptospira, que inclui espécies patogênicas e saprófitas (não patogênicas) (Ko et al., 2009). Em estudos anteriores realizados pelo nosso grupo, observou-se que leptospiras patogênicas são resistentes ao tratamento com SHN, enquanto espécies não patogênicas morrem rapidamente, revelando a importância do Complemento para a proteção do hospedeiro, uma vez que a inativação do soro a $56{ }^{\circ} \mathrm{C}$ por 30 min promove a sobrevivência desta bactéria in vitro (Jonhson e Muschel, 1965; Meri et al., 2005; Barbosa et al., 2009).

Leptospiras patogênicas expressam uma série de proteínas em sua superfície com a capacidade de interagir com moléculas da matriz extracelular e células do hospedeiro (Barbosa et al., 2006). A interação com reguladores negativos do Complemento como o FH e o C4BP com a proteína de membrana LcpA (leptospiral complement regulator-acquiring protein A) presente somente nas estirpes patogênicas pode contribuir para a regulação negativa das três vias do Complemento. Esta proteína ainda é capaz de interferir na formação da Via Terminal, através de sua interação com a Vitronectina e C9, impedindo a deposição do MAC na superfície da bactéria (Barbosa et al., 2010; da Silva et al., 2015). Além disso, as leptospiras patogênicas secretam proteases capazes de degradar componentes do Complemento, constituindo um importante mecanismo de evasão (Fraga et al., 2014a).

A resistência à ação lítica do Complemento é uma das estratégias adotadas por algumas estirpes de Borrelia burgdorferi que conseguem sobreviver e disseminar no organismo de hospedeiro. Estas bactérias interagem com o FH e FH-like 1 que atuam como cofatores do FI na degradação da molécula C3b. Além disso, estirpes resistentes ao Complemento de B. burgdorferi expressam uma molécula CD59-like que inibe a formação do MAC em sua superfície, protegendo a bactéria da morte mediada pelo Complemento (Alitalo et al., 2001; Pausa et al., 2003). O parasita Schistosoma mansoni emprega estratégias de evasão ao Complemento possibilitando a sua disseminação e sobrevivência por um longo período de tempo no organismo do hospedeiro. Os vermes adultos contém proteínas de membrana que se ligam aos componentes do Complemento $\mathrm{C} 1$ e $\mathrm{C} 2$. A paramiosina, uma proteína muscular presente em invertebrados, liga-se in vitro ao C1q inibindo deste modo, a ativação da Via Clássica do Complemento. Além disso, S. mansoni expressa em sua superfície um inibidor de Complemento (SCIP-1) com características semelhantes ao CD59, inibindo a formação do MAC (Deng et al., 2003). A forma tripomastigota do protozoário Trypanosoma cruzi expressa em sua superfície uma molécula chamada trypomastigote decayaccelerating fator (T-DAF) que inibe a ativação do Complemento de um modo 
funcionalmente semelhante ao regulador humano, sendo capaz de interferir na formação das C3 convertases e desta forma promove resistência à lise mediada pelo Complemento (Tambourgi et al., 1993).

Assim como as leptospiras, outros microrganismos patogênicos também secretam proteases capazes de clivar diferentes componentes do Complemento, apresentado desta forma, uma estratégia de evasão ao sistema imune do hospedeiro. As principais classes de proteases secretadas por bactérias são: cisteíno-, aspartil-, serino- e metalo proteases, que estão envolvidas na clivagem de uma ampla gama de substratos, incluindo moléculas das Vias Alternativa, Clássica e das Lectinas, além de componentes da Via Terminal (Potempa et al., 2012).

Diversas bactérias foram identificadas como sendo capazes de secretar proteínas que interferem especificamente na formação do complexo C5b-9. A bactéria Streptococcus pyogenes secreta as proteínas streptococcal pyrogenic exotoxin $B(\mathrm{SpeB})$ e streptococcal inhibitor of complement (SIC). A SpeB é uma protease capaz de clivar as proteínas C6, C7, C8 e C9 (Honda-Ogawa et al., 2013). Já a proteína SIC atua como um inibidor, bloqueando o sítio de inserção à membrana do complexo C5b-7 e, portanto, impedindo a formação do MAC na superfície da bactéria (Akesson et al., 1996). Além disso, Staphylococcus aureus secreta a staphylococcal superantigen-likeprotein 7 (SSL7), que se liga à molécula C5 impedindo a sua proteólise pela C5-convertase. Como resultado, SSL7 bloqueia a geração de C5a e C5b, e ainda é capaz de se ligar diretamente ao C5b impedindo assim, a montagem do MAC (Langley et al., 2005).

Em um estudo anterior realizado por nosso grupo, foi observado que leptospiras patogênicas secretam proteases capazes de clivar certas proteínas do Complemento, enquanto as saprófitas não apresentam atividade proteolítica significativa sobre tais moléculas. As proteases secretadas pelas leptospiras patogênicas degradam a molécula central C3, assim como seus fragmentos C3b e iC3b, e também proteínas da via Alternativa (FB), Clássica e das Lectinas (C4b e C2) (Fraga et al., 2014b). Dada à importância deste mecanismo de evasão descrito, decidimos investigar neste trabalho a atividade proteolítica do sobrenadante de leptospiras sobre proteínas que formam o MAC. No estudo realizado pelo nosso grupo, a atividade proteolítica das proteases secretadas pelas leptospiras patogênicas sobre o componente C5 foi observada somente quando utilizamos a proteína purificada, não havendo clivagens no SHN. Baseado nos resultados obtidos uma possível explicação seria o fato da 
clivagem de C5 ter sido afetada por uma competição entre diferentes substratos (proteínas do Complemento entre outros) presentes no soro (Fraga et al., 2014b).

Neste projeto observamos que proteases presentes nos sobrenadantes de cultura de diferentes estirpes patogênicas de leptospiras são capazes de clivar as proteínas C6, C7, C8 e C9 do MAC (Figura 8). Já os sobrenadantes das espécies saprófitas não possuem atividade proteolítica sobre estas moléculas.

Em seguida, verificamos que as clivagens das moléculas C6-C9 ocorrem de modo seletivo, pois mesmo em condições com baixas quantidades de sobrenadantes (proporção enzima/substrato de 1:70), ainda foi possível observar a geração de produtos de clivagem das proteínas do Complemento (Figura 9). Além disso, observamos também que estas clivagens foram tempo-dependentes, ou seja, foram mais pronunciadas com o aumento do tempo de incubação (Figuras 10 e 11).

Realizamos também ensaios de clivagem utilizando SHN como fonte de Complemento. Nesta condição não foi possível observar a proteólise das moléculas C6-C9 do MAC (Figura 13). Isso pode ter ocorrido devido à existência de inibidores de protease presentes no soro, tais como a $\alpha_{2}$-macroglobulina, que poderiam inibir a atividade das proteases responsáveis pelas clivagens das proteínas do C6-C9. A $\alpha_{2}$-macroglobulina é uma glicoproteína encontrada em quantidade abundante no SHN e é conhecida pela sua capacidade em inibir diversas classes de endopeptidases. (Armstrong, Quigley; 1999). Assim, para investigar a hipótese de inibição pela $\alpha_{2}$-macroglobulina, efetuamos ensaios de inibição utilizando essa molécula na mesma concentração sérica. Verificamos que a $\alpha_{2}$-macroglobulina apresentou atividade inibitória sobre as proteases secretadas pelas leptospiras patogênicas (Figura 14). Contudo, a inibição observada foi parcial e apresentou um perfil diferente do que obtivemos com a 1,10-fenantrolina.

Outra hipótese que poderia explicar a ausência de clivagem das proteínas C6-C9 quando utilizamos SHN, seria a existência de uma possível competição pelos diferentes substratos presentes ao mesmo tempo no soro que são passíveis de clivagem pelas proteases de leptospira. Nesse sentido, haveria uma maior disponibilidade de proteínas do Complemento como C3 e C4, as quais se encontram em concentrações mais elevadas no soro em relação às proteínas do $\mathrm{MAC}$, e que também são alvo de clivagem pelas proteases de leptospira (Fraga et al., 2014b). Vale ressaltar ainda que as clivagens das proteínas C3, C4, FB e C2 pelas proteases de leptospiras são observadas na forma de proteína purificada e 
também quando utilizamos soro como fonte de Complemento. Além disso, como estamos trabalhando com sobrenadante total das leptospiras, outra possibilidade seria a existência de diferentes proteases atuando nas moléculas C3, C4, Fator B, C2 e nas proteínas C6-C9 do MAC. Considerando essa hipótese, também é possível que as proteases responsáveis pelas clivagens de C6-C9 sejam inibidas na presença do SHN, ao passo que aquelas que clivam os demais componentes não.

Mesmo não observando clivagem das moléculas C6-C9 no soro por proteases de leptospira, devemos ressaltar que há possibilidade de atuação das proteases de leptospira sobre as moléculas da Via Terminal em outros locais do hospedeiro colonizados pela bactéria. Após a fase inicial de infecção, as leptospiras, que possuem característica altamente invasiva, colonizam diversos tecidos, como o fígado, rins e pulmões. Nestes tecidos também há presença do Sistema Complemento, o qual deve ser inativado para que o processo infeccioso ocorra com sucesso. Assim, nesse contexto, a secreção de proteases que atuam sobre as moléculas C6-C9 poderia contribuir para o estabelecimento da infecção nos diferentes órgãosalvo afetados na leptospirose.

De forma interessante, observamos também que as proteases secretadas pelas leptospiras patogênicas são capazes de clivar o complexo solúvel SC5b-9 (Figura 15). Esse complexo possui importantes atividades pró-inflamatórias que atuam diretamente sobre o endotélio como a indução de moléculas de adesão, além de desencadear ativação das células ao invés de induzir morte celular (Yang et al., 2014). Deste modo, a clivagem do complexo solúvel SC5b-9 pelas proteases de leptospira poderia ter importantes consequências para o processo infeccioso, uma vez que sua degradação poderia resultar em uma redução do processo inflamatório e dos níveis de ativação celular, constituindo assim uma estratégia de evasão imune adicional apresentada pelas leptospiras patogênicas.

Com a finalidade de determinar quais as possíveis classes de proteases envolvidas nas clivagens das proteínas $\mathrm{C6}$-C9, ensaios com inibidores das principais classes de proteases foram efetuados. Observamos a inibição da atividade proteolítica pela 1,10-fenantrolina, o que indica a participação preponderante de metalo proteases (Figura 12). Esse dado corrobora os resultados previamente obtidos por Fraga et al. (2014b), que mostram a atuação de metalo proteases na clivagem de componentes do Sistema Complemento. Entretanto, não podemos descartar a participação de outras classes de proteases nas clivagens das proteínas do MAC. Uma vez ocorrendo a primeira clivagem das proteínas C6, C7, C8 e C9 pelas metalo proteases secretadas exclusivamente por espécies patogênicas de leptospiras, novos sítios de clivagem 
para outras enzimas atuarem podem ser expostos nessas proteínas da Via Terminal. Estes novos sítios podem ser passíveis de clivagem tanto por esta mesma metalo protease quanto por outras enzimas, que podem ser da mesma classe ou não. Além disso, estas proteases que atuariam em um segundo momento, poderiam ser exclusivas ou não das estirpes patogênicas, uma vez que a sua atuação dependeria da primeira clivagem que ocorre apenas por ação de proteases secretadas por estas bactérias, e não pelas saprófitas.

Visto que os ensaios de inibição mostraram que as metalo proteases são uma das classes de enzimas responsáveis pelas clivagens das proteínas C6-C9, achamos que seria relevante testar a atividade da Termolisina, uma metalo protease expressa exclusivamente por estirpes patogênicas de leptospira capaz de clivar a molécula C3 (Fraga et al., 2014b). Dentre as proteínas do MAC analisadas aqui neste projeto, somente o componente C6 foi alvo de clivagem pela Termolisina recombinante (Figura 18). De forma interessante, a Termolisina foi capaz de clivar a proteína C6 tanto purificada, quanto como parte integrante do complexo solúvel SC5b-9.

Entretanto, verificamos que a Termolisina não foi capaz de clivar os componentes C7, C8 e C9 da Via Terminal. Analisando a sequência primária destas proteínas, podemos observar que há diversos domínios em comum entre estas moléculas e o componente C6 do Complemento (Figura 5). Neste sentido, perguntamo-nos se a Termolisina, apesar de não exercer atividade proteolítica sobre os demais componentes do MAC, poderia interagir com estas moléculas, o que resultaria em um efeito adicional de inibição por interação direta, caracterizando assim um novo mecanismo de evasão atribuído a protease de leptospira. De fato, conseguimos observar que a Termolisina é capaz de interagir com todas as proteínas do MAC aqui estudadas (C6-C9) (Figuras 20 e 22), mas exerce atividade proteolítica somente sobre o componente C6. Entretanto, podemos observar que C6 apresentou uma clivagem mais acentuada quando utilizamos o sobrenadante total de leptospira em comparação com a Termolisina recombinante. Este fato poderia ser explicado pela existência de outras proteases além da Termolisina atuando na clivagem de C6, quando utilizamos o sobrenadante total. Além disso, outra hipótese que poderia explicar essa menor degradação, seria devido ao fato de estarmos comparando a atividade de proteases nativas presentes no sobrenadante total das leptospiras com uma protease recombinante, que foi submetida a um processo de purificação e renovelamento, e que possivelmente não está com sua atividade máxima.

A molécula C6 desempenha um papel essencial tanto na formação como na estrutura do MAC (DiScipio, Hugli, 1989). A degradação desta molécula seria uma forma de evitar a 
completa interação das moléculas que compõem o MAC com a superfície do patógeno, uma vez que apenas quando a molécula C7 se liga ao complexo C5b-6, há a associação com a superfície do patógeno. Desta forma, a secreção da Termolisina pelas leptospiras patogênicas impede a atuação do Complemento sobre a sua superfície através da clivagem da molécula C6. Entretanto, é necessário investigar com maior detalhe os sítios de clivagens obtidos através da atividade proteolítica da Termolisina exercida sobre o componente C6 do Complemento.

Em um estudo realizado por Hallström e colaboradores, verificou-se que a heparina foi capaz de bloquear a ligação entre a Proteína E presente na membrana da bactéria Haemophilus influenzae com a Vitronectina. Entretanto, essa interação não foi dependente de força iônica (Hallström et al., 2009). Neste trabalho, observamos que a interação entre a Termolisina recombinante com a proteína C6 do Complemento foi afetada na presença de heparina de maneira dose-dependente. No que diz respeito ao papel da força iônica, somente quando adicionamos elevadas concentrações de $\mathrm{NaCl}$, observamos uma inibição da interação entre Termolisina-C6.

Por fim, com a finalidade de comprovar a capacidade inibitória da Termolisina, efetuamos um ensaio funcional no qual as proteínas $\mathrm{C} 7, \mathrm{C} 8$ e C9 foram pré-incubadas com a proteína recombinante e posteriormente adicionadas a eritrócitos de carneiro previamente revestidos com o complexo C5b6 (Figura 23). Neste ensaio verificamos que a Termolisina foi capaz de inibir a hemólise dos eritrócitos, comprovando assim que a protease secretada pelas leptospiras patogênicas é capaz de inibir in vitro a formação do MAC, neutralizando a função lítica do Complemento.

Com os dados obtidos, podemos inferir que a inibição pela Termolisina sobre a Via Terminal ocorre de dois modos distintos (i) pela clivagem do componente C6, que se dá com a proteína isoladamente ou como parte do complexo SC5b-9 e (ii) pela interação direta entre a protease e as demais proteínas C7, C8 e C9 (Figura 24). Deste modo, acreditamos que os resultados apresentados neste trabalho possam contribuir para a caracterização de um importante mecanismo de evasão pelas leptospiras patogênicas: a secreção de proteases que clivam componentes do Sistema Complemento humano e ainda fornecer informações relevantes tanto para o conhecimento da patogênese do microrganismo, bem como de potencial importância terapêutica e preventiva em leptospirose. 


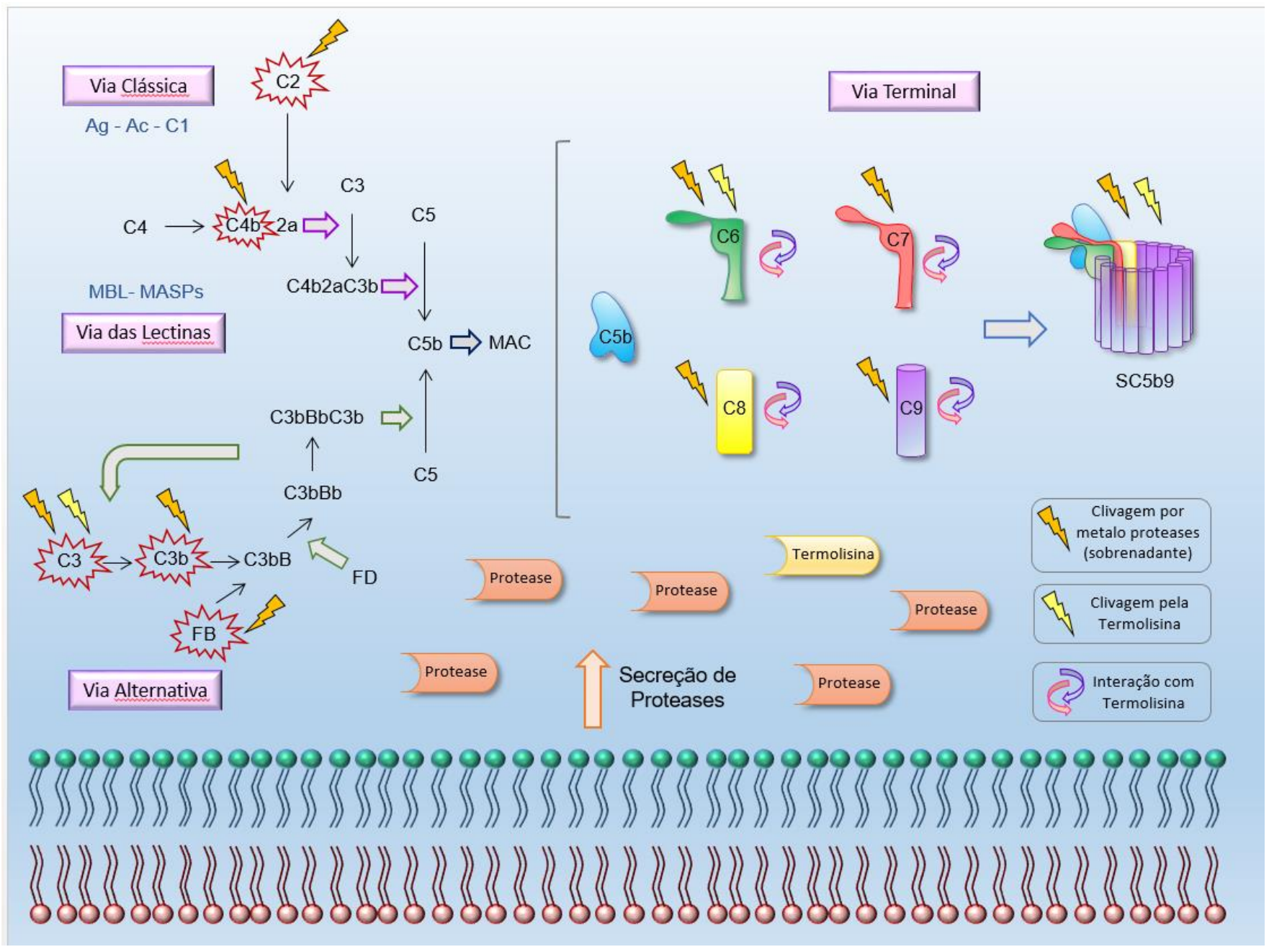

Figura 24 - Representação esquemática da atuação das proteases secretadas pelas leptospiras patogênicas sobre as proteínas do Sistema Complemento. Metalo proteases secretadas exclusivamente por estirpes patogênicas de leptospira são capazes de clivar a proteína central C3, moléculas da Via Alternativa (FB), da Via Clássica e das Lectinas (C4b e C2) (Fraga et al., 2014b). Neste trabalho, demonstramos que as proteases secretadas também tem como alvo componentes do MAC, tanto purificados (C6, C7, C8 e C9) quanto como parte do complexo solúvel SC5b-9. Dentre as proteases secretadas, a Termolisina, uma metalo protease expressa apenas por estirpes patogênicas de leptospira, é capaz de clivar o componente C6. Além disso, a Termolisina pode interferir com a formação do MAC pela interação direta com as moléculas C7, C8 e C9 do Complemento. 
6 CONCLUSÕES 


\section{Resumo dos principais resultados obtidos:}

- As proteases secretadas por cinco diferentes tipos de leptospiras patogênicas são capazes de clivar os componentes do MAC: C6, C7, C8 e C9;

- Os sobrenadantes de duas estirpes não patogênicas de L. biflexa não apresentaram atividade proteolítica sobre as moléculas C6-C9;

- As clivagens das proteínas estudadas (C6-C9) do MAC foram tempo-dependentes, ou seja, com o aumento do tempo de incubação houve uma clivagem mais pronunciada dos substratos;

- As proteases secretadas pelas leptospiras patogênicas foram capazes de clivar as proteínas (C6-C9) do MAC mesmo em quantidades reduzidas dos sobrenadantes;

- Ensaios de inibição utilizando inibidores de proteases mostraram que enzimas da classe das metalo proteases estão envolvidas nas clivagens das proteínas C6-C9;

- As proteases secretadas pelas leptospiras patogênicas não apresentaram atividade proteolítica, quando SHN foi empregado como fonte de Complemento;

- O complexo solúvel SC5b-9 foi clivado pelas proteases das leptospiras patogênicas;

- A Termolisina recombinante, uma metalo protease de Leptospira interrogans, foi capaz de clivar o componente C6 do MAC tanto purificado quanto como parte integrante do complexo solúvel SC5b-9;

- A Termolisina recombinante interagiu com os componentes C6, C7, C8 e C9 inibindo a formação do MAC. 
Este trabalho teve como objetivo investigar a atividade proteolítica dos sobrenadantes de leptospiras sobre os componentes C6, C7, C8 e C9 do Complemento. Com base nos resultados obtidos podemos concluir que os sobrenadantes de culturas de leptospiras patogênicas foram capazes de clivar tais moléculas, ao passo que os sobrenadantes de espécies não patogênicas não apresentaram atividade proteolítica significante sobre estes substratos. Tal atividade proteolítica foi unicamente observada com as proteínas purificadas, mas não no soro completo, possivelmente pela presença de inibidores de proteases como, por exemplo, a $\alpha_{2}$-macroglobulina, presente em elevada concentração no soro.

Enzimas da classe das metalo proteases estão possivelmente envolvidas nas clivagens observadas. Dentre estas, proteases da família das Termolisinas são fortes candidatas a participarem das degradações, uma vez que a forma recombinante da Termolisina LIC 13322 foi capaz de clivar a molécula C6 do complemento, tanto a proteína individualmente quanto como parte integrante do complexo solúvel SC5b-9. Além disso a Termolisina recombinante ainda foi capaz de interagir com as proteínas C6, C7, C8 e C9, indicando um fator adicional de inibição da ação do Complemento por interação direta.

Deste modo, a identificação de alvos biológicos para as proteases de leptospira é de grande importância para o melhor entendimento da patogênese da doença, bem como também poderá contribuir para o desenvolvimento de estratégias terapêuticas e/ou preventivas na infecção por estes patógenos. 


\section{REFERÊNCIAS*}

Adler B, Moctezuma AP. Leptospira and leptospirosis. Veterinary Microbiology. 2009; 140(3):287-96.

Akesson P, Sjöholm AG, Björck L. Protein SIC, a novel extracellular protein of Streptococcus pyogenes interfering with complement function. $\mathrm{J}$ Biol Chem. 1996;271(2):1081-88.

Aleshin AE, Schraufstatter IU, Stec B, Bankston LA, Liddington RC, DiScipio RG. Structure of complement C6 suggests a mechanism for initiation and unidirectional, sequential assembly of membrane attack complex (MAC). J Biol Chem. 2012;287(13):10210-22.

Alitalo, A., T. Meri, L. Ramo, T. S. Jokiranta, T. Heikkila, I. J. Seppala, J. Oksi, M. Viljanen, and S. Meri. Complement evasion by Borrelia burgdorferi: serum-resistant strains promote C3b inactivation. Infect. Immun. 2001;69:3685.

Armstrong PB, Quigley JP. Alpha2-macroglobulin: an evolutionarily conserved arm of the innate immune system. Dev Comp Immunol. 1999;23(4-5):375-90.

Barbosa, A. S., P. A. Abreu, F. O. Neves, M. V. Atzingen, M. M. Watanabe, M. L. Vieira, Z. M. Morais, S. A. Vasconcellos, and A. L. Nascimento. A newly identified leptospiral adhesin mediates attachment to laminin. Infect. Immun. 2006;74:6356-64.

Barbosa AS, Abreu PA, Vasconcellos SA, Morais ZM, Gonçales AP, Silva AS, Daha MR, Isaac L. Immune evasion of leptospira species by acquisition of human complement regulator C4BP. Infect Immun. 2009;77(3):1137-43.

Barbosa AS, Monaris D, Silva LB, Morais ZM, Vasconcellos SA, Cianciarullo AM, Isaac L, Abreu PA. Functional characterization of LcpA, a surface-exposed protein of Leptospira spp. that binds the human complement regulator C4BP. Infect Immun. 2010;78(7):3207-16.

Barroso S, Rieubland C, Alvarez AJ, Lopez-Trascasa M, Bart PA, Nunez-Roldan A, Sanchez B. Molecular defects of the $\mathrm{C} 7$ gene in two patients with complement C7 deficiency. Immunology. 2006;118(2):257-60.

Barroso S, Sanchez B, Alvarez AJ, Lopez-Trascasa M, Lanuza A, Luque R, Wichmann I, Nunez-Roldan A. Complement component C7 deficiency in two Spanish families. Immunology. 2004;113(4):518-23.

Behnsen J, Lessing F, Schindler S, Wartenberg D, Jacobsen I.D, Thoen M, Zipfel PF, Brakhage AA. Secreted Aspergillus fumigatus protease Alp1 degrades human complement proteins C3, C4, and C5. Infect Immun. 2010;78(8):3585-94.

\footnotetext{
* De acordo com:

International Committee of Medical Journal Editors. [Internet]. Uniform requirements for manuscripts submitted to Biomedical Journal: sample references. [updated 2011 Jul 15]. Available from: http://www.icmje.org
} 
Berends ET, Kuipers A, Ravesloot MM, Urbanus RT, Rooijakkers SH. Bacteria under stress by complement and coagulation. FEMS Microbiol Rev. 2014;38(6):1146-71.

Bhakdi S, Käflein R, Halstensen TS, Hugo F, Preissner KT, Mollnes TE. Complement Sprotein (vitronectin) is associated with cytolytic membrane-bound C5b-9 complexes. Clin Exp Immunol. 1988 Dec;74(3):459-64.

Bharti AR, Nally JE, Ricaldi JN, Matthias MA, Dias MM, Lovett MA, Levett PN, Gilman RH, Willig MR, Gotuzzo E, Vinetz JM. Leptospirosis: a zoonotic disease of global importance. Lancet Infect Dis. 2003;3(12):757-71.

Bohlson SS, O'Conner SD, Hulsebus HJ, Ho MM, Fraser DA. Complement, c1q, and c1qrelated molecules regulate macrophage polarization. Front Immunol. 2014;5:402.

Bubeck D, Roversi P, Donev R, Morgan BP, Llorca O, Lea SM. Structure of human complement $\mathrm{C} 8$, a precursor to membrane attack. Journal of Molecular Biology. 2011;405(2),325-30.

Bubeck D. The making of a macromolecular machine: assembly of the membrane attack complex. Biochemistry 2014;53(12),1908-15.

Carroll MC, Isenman DE. Regulation of humoral immunity by complement. Immunity. 2012;37(2):199-207

Castiblanco-Valencia MM, Fraga TR, Pagotto AH, Serrano SM, Abreu PA, Barbosa AS, Isaac L. Plasmin cleaves fibrinogen and the human complement proteins $\mathrm{C} 3 \mathrm{~b}$ and $\mathrm{C} 5$ in the presence of Leptospira interrogans proteins: A new role of LigA and LigB in invasion and complement immune evasion. Immunobiology. 2016;221(5):679-89. doi: 10.1016/j.imbio.2016.01.001.

Castiblanco-Valencia MM, Fraga TR, Silva LB, Monaris D, Abreu PA, Strobel S, Józsi M, Isaac L, Barbosa AS. Leptospiral immunoglobulin-like proteins interact with human complement regulators factor H, FHL-1, FHR-1, and C4BP.J Infect Dis. 2012;205(6):9951004.

Cerqueira GM, Picardeau M. A century of Leptospira strain typing. Infection, Genetics and Evolution. 2009;9(5):760-8.

Costa F, Hagan JE, Calcagno J, Kane M, Torgerson P, Martinez-Silveira MS, Stein C, AbelaRidder B, Ko AI. Global morbidity and mortality of leptospirosis: A systematic review. PLoS Negl Trop Dis. 2015;9(9):e0003898.

Cumberland P, Everard CO, Levett PN. Assessment of the efficacy of an IgM-elisa and microscopic agglutination test (MAT) in the diagnosis of acute leptospirosis. Am J Trop Med Hyg. 1999 Nov;61(5):731-4.

Daffern PJ, Pfeifer PH, Ember JA, Hugli TE. C3a is a chemotaxin for human eosinophils but not for neutrophils. I. C3a stimulation of neutrophils is secondary to eosinophil activation. $\mathrm{J}$ Exp Med. 1995; 181(6): 2119-27. 
da Silva LB, Miragaia L dos S, Breda LC, Abe CM, Schmidt MC, Moro AM, Monaris D, Conde JN, Józsi M, Isaac L, Abreu PA, Barbosa AS. Pathogenic Leptospira species acquire factor $\mathrm{H}$ and vitronectin via the surface protein LcpA. Infect Immun. 2015;83(3):888-97.

Dempsey PW, Allison ME, Akkaraju S, Goodnow CC, Fearon DT. C3d of complement as a molecular adjuvant: bridging innate and acquired immunity. Science. 1996;271(5247):348-50.

Deng J, Gold D, LoVerde PT, Fishelson Z. Inhibition of the complement membrane attack complex by Schistosoma mansoni paramyosin. Infect Immun. 2003;(11):6402-10.

Dias Da Silva W, Lepow IH. Complement as a mediator of inflammation. II. Biological properties of anaphylatoxin prepared with purified components of human complement. J Exp Med. 1967;125(5):921-46.

DiScipio RG, Chakravarti DN, Muller-Eberhard HJ, Fey GH. The structure of human complement component C7 and the C5b-7 complex. J. Biol. Chem. 1988;263:549-60.

DiScipio RG, Gehring MR, Podack ER, Kan CC, Hugli TE, Fey GH. Nucleotide sequence of cDNA and derived amino acid sequence of human complement componente C9. Proc. Nat. Acad. Sci. 1984;81(23):7298-302.

DiScipio RG, Hugli TE. The architecture of complement component C9 and poly (C9). J. Biol. Chem.1985;260(27):14802-9.

DiScipio RG, Hugli TE. The molecular architecture of human complement component C6. J. Biol. Chem. 1989;264(27):16197-206.

Dobó J, Schroeder V, Jenny L, Cervenak L, Závodszky P, Gál P. Multiple roles of complement MASP-1 at the interface of innate immune response and coagulation. Mol Immunol. 2014;61(2):69-78.

Dobó J, Szakács D, Oroszlán G, Kortvely E, Kiss B, Boros E, Szász R, Závodszky P, Gál P, Pál G. MASP-3 is the exclusive pro-factor D activator in resting blood: the lectin and the alternative complement pathways are fundamentally linked. Sci Rep. 2016;6:31877.

Dunkelberger JR, Song WC. Complement and its role in innate and adaptive immune responses. Cell Res. 2010;20(1):34-50.

Evangelista KV, Coburn J. Leptospira as an emerging pathogen: a review of its biology, pathogenesis and host immune responses. Future Microbiol. 2010;5(9):1413-1425.

Faine S, Adler B, Bolin C, Perolat P. Leptospira and leptospirosis. 2.ed. Melbourne: MedSci 1999; p. 353.

Faisal SM, Yan W, Chen CS, Palaniappan RU, McDonough SP, Chang YF. Evaluation of protective immunity of Leptospira immunoglobulin like protein A (LigA) DNA vaccine against challenge in hamsters. Vaccine. 2008;26(2):277-87. 
Fang Y, Xu C, Fu YX, Holers VM, Molina H. Expression of complement receptors 1 and 2 on follicular dendritic cells is necessary for the generation of a strong antigen-specific IgG response. J Immunol. 1998;160(11):5273-9.

Farkas I, Baranyi L, Ishikawa Y, Okada N, Bohata C, Budai D, Fukuda A, Imai M, Okada H. CD59 blocks not only the insertion of C9 into MAC but inhibits ion channel formation by homologous C5b-8 as well as C5b-9. The Journal of Physiology. 2002;539(2):537-45.

Fraga TR, Carvalho E, Isaac L, Barbosa A S. Leptospira and Leptospirosis. In: Tang YW, Sussman M, Liu D, Poxton, Schwartzman J (Eds.). Molecular Medical Microbiology. 2 ed. London: Elsevier,2014a. v.3:2145.

Fraga TR, Courrol DS, Castiblanco-Valencia MM, Hirata IY, Vasconcellos AS, Juliano L, Barbosa AS, Isaac L. Immune evasion by pathogenic leptospira strains: the secretion of proteases that directly cleave complement proteins. J Infect Dis. 2014b;209(6):876-86.

Forster KM, Hartwig DD, Seixas FK, Bacelo KL, Amaral M, Hartleben CP, Dellagostin OA. A conserved region of leptospiral immunoglobulin-like A and B proteins as a DNA vaccine elicits a prophylactic immune response against leptospirosis. Clin Vaccine Immunol. 2013;20(5):725-31.

Goris MG, Leeflang MM, Loden M, Wagenaar JF, Klatser PR, Hartskeerl RA, Boer KR. Prospective evaluation of three rapid diagnostic tests for diagnosis of human leptospirosis. PLoS Negl Trop Dis. 2013;7(7):e2290.

Gropp K, Schild L, Schindler S, Hube B, Zipfel PF, Skerka C. The yeast Candida albicans evades human complement attack by secretion of aspartic proteases. Molecular Immunology. 2009;47(2):465-75.

Hadders MA, Bubeck D, Roversi P, Hakobyan S, Forneris F, Morgan BP, Pangburn MK, Llorca O, Lea SM, Gros P. Assembly and regulation of the membrane attack complex based on structures of C5b6 and sC5b9. Cell Rep. 2012;1(3):200-7. doi: 10.1016/j.celrep.2012.02.003.

Hadders MA, Beringer DX, Gros P. Structure of C8a-MACPF Reveals Mechanism of Membrane Attack in Complement Immune Defense. Science. 2007;317(5844):1552-4.

Hallström T, Blom AM, Zipfel PF, Riesbeck K. Nontypeable Haemophilus influenzae protein E binds vitronectin and is important for serum resistance. J Immunol. 2009;183(4):2593-601.

Hobart MJ, Fernie B, DiScipio RG.Structure of the human C6 gene. Biochemistry. 1993;32(24):6198-205.

Honda-Ogawa M, Ogawa T, Terao Y, Sumitomo T, Nakata M, Ikebe K, Maeda Y, Kawabata S. Cysteine proteinase from Streptococcus pyogenes enables evasion of innate immunity via degradation of complement factors.J Biol Chem. 2013;288(22): 15854-64.

Johnson RC, Muschel LH. Antileptospiral activity of normal serum. J Bacteriol. 1965;89:1625-6. 
Jusko M, Potempa J, Kantyka T, Bielecka E, Miller HK, Kalinska M, Dubin G, Garred P, Shaw LN, Blom AM. Staphylococcal proteases aid in evasion of the human complement system. J Innate Immun. 2014;6(1):31-46.

Kang HJ, Kim HS, Lee YK, Cho HC. High incidence of complemente C9 deficiency in Koreans. Ann. Clin. Lab. Sci. 2005;35(2):144-8.

Kitashoji E, Koizumi N, Lacuesta TLV, Usuda D, Ribo MR, Tria ES, Go WS, Kojiro M, Parry CM, Dimaano EM, Villarama JB, Ohnishi M, Suzuki M, Ariyoshi K. Diagnostic accuracy of recombinant immunoglobulin-like protein A-Based IgM ELISA for the early diagnosis of leptospirosis in the Philippines. Neglected Tropical Diseases. 2015;9(6):e0003879.

Klos A, Tenner AJ, Johswich KO, Ager RR, Reis ES, Köhl J. The role of the anaphylatoxins in health and disease. Mol Immunol. 2009;46(14):2753-66.

Ko AI, Goarant C, Picardeau M. Leptospira: the dawn of the molecular genetics era for na emerging zoonotic pathogen. Nat Rev Microbiol. 2009;7(10):736-47.

Kojima T, Horiuchi T, Nishizaka H, Fukumori Y, Amano T, Nagasawa K, Niho Y, Hayashi $\mathrm{K}$. Genetic Basis of Human Complement C8a-g Deficiency. The Journal of Immunology. 1998;161(7):3762-6.

Laarman AJ, Bardoel BW, Ruyken M, Fernie J, Milder FJ, van Strijp JAG, Rooijakkers SHM. Pseudomonas aeruginosa alkaline protease blocks complement activation via the classical and lectin pathways. The Journal of Immunology. 2012;188(1):386-93.

Lambris JD, Ricklin D,. Geisbrecht BV. Complement evasion by human pathogens. Nature Reviews Microbiology. 2008; (6):132-142.

Langley R, Wines B, Willoughby N, Proft T, Fraser JD, Basu, I. The staphylococcal superantigen-like protein 7 binds IgA and complement C5 and inhibits IgAFcaRI binding and serum killing of bacteria. J Immunol. 2005;174(5): 2926-33.

Lappegård KT, Garred P, Jonassond L, Espevike T, Aukrustf P, Yndestadf A, Mollnes TE, Hovlanda A. A vital role for complement in heart disease. Molecular Immunology. 2014;61(2):126-34.

Laudisi F1, Spreafico R, Evrard M, Hughes TR, Mandriani B, Kandasamy M, Morgan BP, Sivasankar B, Mortellaro A. Cutting edge: the NLRP3 inflammasome links complementmediated inflammation and IL-1 $\beta$ release. J Immunol. 2013 Aug 1;191(3):1006-10. doi: 10.4049/jimmunol.1300489.

Lee, L. Y., M. Hook, D. Haviland, R. A. Wetsel, E. O. Yonter, P. Syribeys, J. Vernachio, and E. L. Brown. Inhibition of complement activation by a secreted Staphylococcus aureus protein. J. Infect. Dis. 2004;190:571.

Letunic I, Doerks T, Bork P. SMART 7: recent updates to the protein domain annotation resource. Nucleic Acids Res. 2012;40(Database issue):D302-5. 
Levett PN. Leptospirosis. Clin Microbiol Rev. 2001;14(2):296-326.

Levett PN. Systematics of leptospiraceae. In Adler B. Leptospira and Leptospirosis. New York: Springer; 2015.11-20.

Mandujano-González V, Villa-Tanaca L, Anducho-Reyes MA, Mercado-Flores Y. Secreted fungal aspartic proteases: A review. Rev Iberoam Micol. 2016;S1130-1406(16):4-8.

Manthey HD, Woodruff TM, Taylor SM, Monk PN. Complement Component C5 (C5a). J Biochem Cell Biol. 2009:85:213-217.

Meri T, Murgia R, Stefanel P, Meri S, Cinco M. Regulation of complement activation at the C3-level by serum resistant leptospires. Microb Pathog. 2005;39(4):139-47.

Meri T, Cutler SJ, Blom AM, Meri S, Jokiranta TS. Relapsing fever spirochetes Borrelia recurrentis and $B$. duttonii acquire complement regulators $\mathrm{C} 4 \mathrm{~b}$-binding protein and factor $\mathrm{H}$. Infect Immun. 2006;74(7):4157-63.

Miwa T, Song WC. Membrane complement regulatory proteins: insight from animal studies and relevance to human diseases. International Immunopharmacology. 2001;1(3):445-459.

Monahan JB, Sodetz JM. Binding of the eighth component of human complement to the soluble cytolytic complex is mediated by its beta subunit. J Biol Chem. 1980;255(22):1057982 .

Müller-Eberhard, H. J. (1986). The membrane attack complex of complement. Annu Rev Immunol 4: 503-28

Orren A, Owen EP, Henderson HE, van der Merwe L, Leisegang F, Stassen C, Potter PC. Complete deficiency of the sixth complement component (C6Q0), susceptibility to Neisseria meningitidis infections and analysis of the frequencies of C6Q0 gene defects in South Africans. Clinical \& Experimental Immunology. 2011;167(3): 459-71.

Palaniappan RU, Ramanujam S, Chang YF. Leptospirosis: pathogenesis, immunity, and diagnosis. Curr Opin Infect Dis. 2007;20(3):284-92.

Palaniappan, RUM; McDonough, SP; Divers, TJ; Chen, CS; Pan, MJ; Matsumoto, M; Chang, YF. Immunoprotection of Recombinant Leptospiral Immunoglobulin-Like Protein A against Leptospira interrogans Serovar Pomona Infection. Infection and Immunity. 2006;74(3), 174550 .

Paster BJ, Dewhirst FE, Weisburg WG, Tordoff LA, Fraser GJ, Hespell RB, Stanton TB, Zablen L, Mandelco L, Woese CR. Phylogenetic analysis of the spirochetes. J Bacteriol. 1991;173(19):6101-9.

Pausa M, Pellis V, Cinco M, Giulianini PG, Presani G, Perticarari S, Murgia R, Tedesco F. Serum-resistant strains of Borrelia burgdorferi evade complement-mediated killing by expressing a CD59-like complement inhibitory molecule. J Immunol. 2003;170(6):3214-22. 
Pfarr N, et al. Linking C5 deficiency to an exonic splicing enhancer mutation. J Immunol. 2005;174(7):4172-7.

Picardeau M. Diagnosis and epidemiology of leptospirosis. Med Mal Infect. 2013;43(1):1-9.

Podack ER, Esser AF, Biesecker G, Müller-Eberhard HJ. Membrane attack complex of complement: a structural analysis of its assembly. J Exp Med. 1980;151(2):301-13.

Potempa M, Potempa J, Kantyka T, Nguyen K, Wawrzonek K, Manandhar SP, Popadiak K, Riesbeck K, Eick S, Blom AM. Interpain A, a cysteine proteinase from Prevotella intermedia, inhibits complement by degrading complement factor C3. PLoS Pathog. 2009;5(2)e1000316.

Potempa M, Potempa J. Protease-dependent mechanisms of complement evasion by bacterial pathogens. Biol. Chem. 2012;393(9):873-88.

Raddi G, Morado DR, Yan $\mathrm{J}$ et al. Three-dimensional structures of pathogenic and saprophytic Leptospira species revealed by cryo-electron tomography. J Bacteriol. 2012; 194:1299-1306.

Ramu P, Tanskanen R, Holmberg M, Lähteenmäki K, Korhonen TK, Meri S. The surface protease PgtE of Salmonella enterica affects complement activity by proteolytically cleaving C3b, C4b and C5. FEBS Letters. 2007;581(9):1716-20.

Ricaldi J, Swancutt MA, Matthias MA. Current trends in translational research in leptospirosis. Curr Opin Infect Dis. 2013;26(5):399-403.

Ricklin D, Hajishengallis G, Yang K, Lambris JD. Complement - a key system for immune surveillance and homeostasis. Nat Immunol. 2010; 11(9): 785-97.

Riva R, Korhonen TK, Meri S. The outer membrane protease PgtE of Salmonella enterica interferes with the alternative complement pathway by cleaving factors B and H.Front Microbiol. 2015;6:63.

Rooijakkers SHM, van Strijp JAG. Bacterial complement evasion. Molecular Immunology 44 (2007) 23-32.

Ross SC, Densen P. Complement deficiency states and infection: epidemiology, pathogenesis and consequences of neisserial and other infections in an immune deficiency. Medicine 1984;63:243-73.

Roussel-Jazédé V, Grijpstra J, van Dam V, Tommassen J, van Ulsen P. Lipidation of the autotransporter NalP of Neisseria meningitidis is required for its function in the release of cell-surface-exposed proteins. Microbiology. 2013;159(2):286-95.

Sarma JV, Ward PA. The Complement System. Cell Tissue Res. 2011;343(1):227-35.

Sahu A, Pangburn M. Identification of multiple sites of interaction between heparin and the Complement System. Molecular Immunology. 1993;30(7):679-84. 
Schreck SF, Parker C, Plumb ME, Sodetz JM. Human complement protein C8 gamma. Biochim Biophys Acta. 2000;1482(1):199-208.

Schreier S, Triampo W, Doungchawee G, Triampo D, Chadsuthi S. Leptospirosis research: fast, easy and reliable enumeration of mobile leptospires. Biological Research. 2009;42(1):512.

Silva EF, Medeiros MA, McBride AJ, Matsunaga J, Esteves GS, Ramos JG, Santos CS, Croda J, Homma A, Dellagostin OA, Haake DA, Reis MG, Ko AI. The terminal portion of leptospiral immunoglobulin-like protein LigA confers protective immunity against lethal infection in the hamster model of leptospirosis. Vaccine. 2007;25:6277-86.

Siqueira GH, Atzingen MV, Alves IJ, de Morais ZM, Vasconcellos SA, Nascimento AL. Characterization of three novel adhesins of Leptospira interrogans. Am J Trop Med Hyg. 2013;89(6):1103-16.

Spichler AS, Vilaça PJ, Athanazio DA, Albuquerque JO, Buzzar M, Castro B, Seguro A, Vinetz JM. Predictors of lethality in severe leptospirosis in urban Brazil. Am J Trop Med Hyg. 2008;79(6):911-4.

Stevenson B, Choy HA, Pinne M, Rotondi ML, Miller MC, Demoll E, Kraiczy P, Cooley AE, Creamer TP, Suchard MA, Brissette CA, Verma A, Haake DA. Leptospira interrogans endostatin-like outer membrane proteins bind host fibronectin, laminin and regulators of complement. PLoS One. 2007 Nov;2(11):e1188.

Stevenson L, Laursen E, Cowan GJ, Bandoh B, Barfod L, Cavanagh DR, Andersen GR, Lars Hviid L. a2-Macroglobulin Can Crosslink Multiple Plasmodium falciparum Erythrocyte Membrane Protein 1 (PfEMP1) Molecules and May Facilitate Adhesion of Parasitized Erythrocytes. PLoS Pathog. 2015; 11(7): e1005022.

Takabe K, Nakamura S, Ashihara M et al. Effect of osmolarity and viscosity on the motilityof pathogenic and saprophytic Leptospira. Microbiol Immunol. 2013;57(3):236-9.

Takizawa F, Tsuji S, Nagasawa S. Enhancement of macrophage phagocytosis upon iC3b deposition on apoptotic cells. FEBS Lett. 1996;397(2-3):269-72.

Tambourgi DV, Kipnis TL, da Silva WD, Joiner KA, Sher A, Heath S, Hall BF, Ogden GB. A partial cDNA clone of trypomastigote decay-accelerating factor (T-DAF), a developmentally regulated complement inhibitor of Trypanosoma cruzi, has genetic and functional similarities to the human complement inhibitor DAF. Infect Immun. 1993;61(9):3656-63.

Tegla CA, Cudrici C, Patel S, Trippe R III, Rus V, Niculescu F, Rus H. Membrane attack by complement: the assembly and biology of terminal complement complexes. Immunol Res. 2011;51(1):45-60.

Verma R, Khanna P, Chawla S. Whole-cell inactivated leptospirosis vaccine: future prospects. Hum Vaccin Immunother. 2013;9(4):763-5 
Vieira ML, Vasconcellos AS, Gonçales AP, Morais ZM, Nascimento ALTO. Plasminogen acquisition and activation at the surface of leptospira species lead to fibronectin degradation. Infection and Immunity. 2009;77(9):4092-101.

Walport MJ. Complement first of two parts. The New England Journal of Medicine. 2001;344 (14):1058-66.

Wolff DG, Castiblanco-Valencia MM, Abe CM, Monaris D, Morais ZM, Souza GO, Vasconcellos AS, Isaac L, Abreu PA, Barbosa AS. Interaction of leptospira elongation factorTu with plasminogen and complement factor $\mathrm{h}$ : a metabolic leptospiral protein with moonlighting activities. PLoS One. 2013;8(11):1-10.

Yang C, Yang L, Liu Y. Soluble complement complex C5b-9 promotes microglia activation. J Neuroimmunol. 2014;267(1):16-9.

Yu NY, Wagner JR, Laird MR, Melli G, Rey S, Lo R, Dao P, Sahinalp SC, Ester M, Foster LJ, Brinkman FS. PSORTb 3.0: improved protein subcellular localization prediction with refined localization subcategories and predictive capabilities for all prokaryotes. Bioinformatics. 2010;26(13):1608-15.

Zipfel PF, Skerka C. Complement regulators and inhibitory proteins. Nat Rev Immunol. 2009;9(10):729-40.

Zipfel PF, Würzner R, Skerka C. Complement evasion of pathogens: common strategies are shared by diverse organisms. Molecular Immunology. 2007;44(16),3850-7. 